\title{
THIG ART OF
}

THE SECOND GROWTH

$$
\text { ํㅏㄹ }
$$

AMERICAN SYLVICWL TURE

5. A. Sctignek, 125, D.

\section{$\mathrm{SD} 143$ \\ $\$ 34$ 1912}




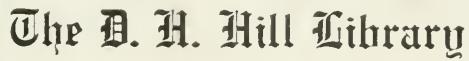

Nurth Carnlina Satp Alniuersity

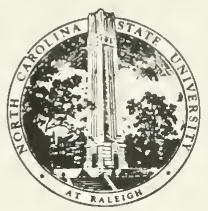

This book was presented by August De Hertogh

\section{SD143}

S34

1912

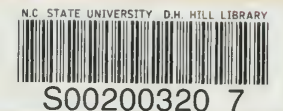


THIS BOOK IS DUE ON THE DATE INDICATED BELOW AND IS SUBJECT TO AN OVERDUE FINE AS POSTED AT THE CIRCULATION DESK.

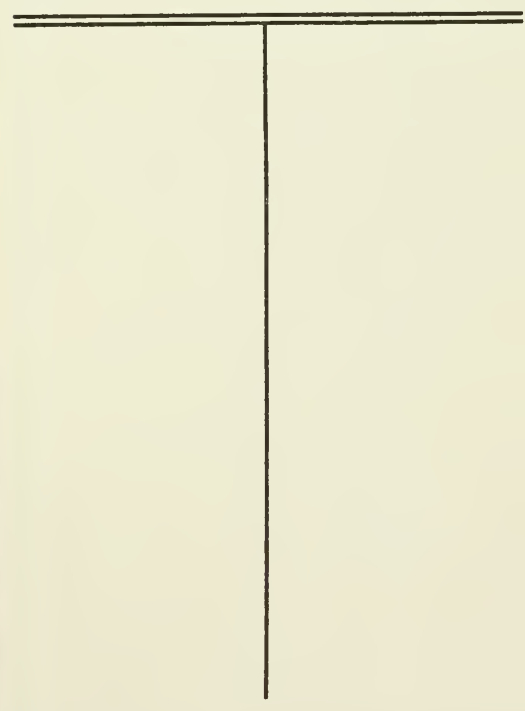





\title{
THE ART OF \\ THE SECOND GROWTH OR \\ AMERICAN SYLVICULTURE
}

\author{
By C. A. SCHENCK, Pн. D.
}

Director of the Biltmore Forest School, Late Forester to the Biltmore Estate, N. C.

THIRD AND REVISED EDITION

ALBANY

THE BRANDOW PRINTING CO.

1912 



\section{PREFACE}

The handbook on "The art of the second growth" or on "American Sylviculture," herewith presented in an enlarged and revised form, is the third issue of a book originally styled "Biltmore Lectures on Sylviculture" when it was first published in 1905 .

The tasks of Sylviculture confronting the American foresters are as diversified as are the conditions governing them in a country like ours which presents, within its two billion acres of land area, the widest and wildest fluctuations of the factors framing the possibility, the intensity, and the methods of American Sylviculture.

The call for Sylviculture arose in the West at a time at which it was hoped that forest plantations might influence favorably the adverse climate of the newly opened prairies.

Since that time, which lies in the seventies of the last century, prairial Sylviculture has lost ground, while its importance, for commonweals as well as for owners of woodlands, has become, in the wooded sections of the country, an issue of American Forestry.

The terms "Sylviculture" and "Forestry" are by no means identical: Forestry comprises any and all work connected with forests, inclusive of all logging and lumbering; Sylviculture is but that part of Forestry which has a second growth for its object. As long as there was at hand in the vast stretches of primeval forests an abundance of first growth, there could exist in the wooded states but little use for "the art of the second growth."

No forester lives who has enjoyed a world's experience in Sylviculture; the forester's experience is local, necessarily; a writer of a book on Sylviculture is apt to apply his local observations to the second growths developing in all the 48 states of the Union. I have tried, in the pages found within the covers of this book, to aroid generalisations based on a local experience, and to write 
a handbook useful to the forester working in a second growth or for a second growth anywhere in this country.

Necessarily, the majority of my own work in Sylviculture was embraced by the 15 years during which I had charge of a vast area of woodlands in western North Carolina. It was my good fortune to be confronted, within this area, by a large diversity of conditions. There were 3,000 acres of abandoned farmland, which I have been insirumental in clothing with a second growth; there were 10,000 acres of woodlands, cut-over, burned over, and neglected before I took charge, which were to be converted into cultured forests; and there was the "Pisgah Forest," primeval woodlands extending over 100,000 acres, situated beyond the reach of the axe, and of little value, extending from the valley of the French Broad River at 2,000 feet elevation to the Balsam Mountains at 6,000 feet eleva. tion. The cut-over woodlands are typical, from the sylvic standpoint, for the Piedmont region of the South; the Pisgah Forest is typical for the conditions prevailing in the Appalachians.

For brevity's sake, these types of conditions are referred to in the following pages by the terms "Biltmore" and "Pisgah Forest." respectively.

Frequent reference is made, also, to the German forests, wherein I have spent the first nine years of my career as a forester; to the Adirondacks to which I was introduced by Dr. B. E. Fernow, Gifford Pinchot, and C. R. Pettis, and which I am visiting annually accompanied by the students of the Biltmore Forest School having its spring quarters in the heart of the Adirondacks. Reference is further made, frequently, to Michigan, where the Biltmore Forest School has its summer camp at Cadillac, Mich., and to Oregon where the Biltmore Forest School sojourns at Marshfield during the fall of every year. The directorate of the Biltmore Forest School, a forest school living in the woods of the North, South, East and West, has forced me to become intimately acquainted with the possibilities of Sylviculture in more than one forest region. It is these facts which lead me to hope that I am submitting to the reader a book on American, and not on local Sylviculture.

I should have liked immensely to insert in this book a large number of pictures illustrative of the matters and things therein deseribed. Unfortunately, the funds at my command did not allow of the additional expense which the extensive use of illustrations would have involved.

This book on "The art of the sccond growth" is the seventh part of an "American Encyclopedia of American Forestry" written and rewritten by me in the course of the last fourteen years. The six 


\section{P R E F A E}

remaining parts of American forestry which I have treated heretofore, by six books or publications, in a similar manner, are analysed in the following schedule:

A. Public Forestry, or forestry by the people, treated as Part I, Forest Policy.

B. Private Forestry, or forestry for the owner, treated as Part II, Forest Utilization, the art of logging and lumbering. Part III, Forest Finance, the art of financial calculations in forestry.

Part IV, Forest Protection, the art of protecting the woods against damage by fire, insects, fungi, etc.

Part V, Forest Mensuration, the art of estimating timber, of measuring the growth of the trees, and of lumber inspection.

Part VI, Forest Management, the art of forest working plans.

The last part is, then,

Part VII, Sylviculture, the art of the second growth.

May the new issue of the present book on Sylviculture find with the American lumberman and with his forester a better reception than that accorded to the original edition! And may it assist in the redemption of the American Forests!

C. A. SCHENCK. 



\section{SYNOPSIS OF PARAGRAPHS}

\section{CHAPTER I.}

\section{Foundations of Sylviculture.}

\section{Paragraph.}

I. Introduction.

II. Ecologic factors and their influence on the sylva.

III. Influence of the sylva on the ecologic factors.

IV. The North American sylva.

V. General definitions and explanations.

VI. Light demanders and shade bearers.

VII. Pure versus mixed woods.

VIII. Dr. Henry Mayr's fundamental principles of sylviculture.

\section{CHAPTER II.}

\section{The Seed Forest.}

IX. Genesis of the seed forest.

$\mathrm{X}$. The seed.

XI. Preparations for direct seeding.

XII. Securing and preparing the seeds.

XIII. Direct seeding.

XIV. Season for direct seeding.

$\mathrm{XV}$. Auxiliaries to direct seeding.

XVI. Direct seeding of the broadleaved species.

XVII. Direct seeding of the coniferous species.

XVIII. Actual planting of seedlings: Introductory remarks.

XIX. Criteria of good seedlings.

XX. Age, size and number of seedlings used.

XXI. Lifting seedlings from nursery bed.

XXII. Transportation of seedlings.

XXIII. Common methods of planting seedlings.

XXIV. Special methods and tools used for planting seedlings.

XXV. Season for planting seedlings.

XXVI. Cultivation of plantations.

XXVII. Prairie planting in particular.

XXVIII. Methods of obtaining plants for planting. 
Paragraph.

XXIX. Permanent nurseries in particular.

XXX. Seed planting in seed beds.

XXXI. Transplanting in transplanting beds.

XXXII. Protection of nurseries.

XXXIII. Nursing in nurseries.

XXXIV. Special nursery methods proclaimed by renowned sylviculturists.

XXXV. Raising and planting hardwood seedlings.

XXXVI. Raising and planting softwood seedlings.

XXXVII. European results of planting experiments with American hardwoods.

XXXVIII. European results of planting experiments with American softwoods.

XXXIX. Difficulties of natural seed regeneration (enesar).

XL. Age of trees fit for natural seed regeneration (enesar).

XLI. Types of natural seed regeneration (enesar).

XLII. Types in which lumbering precedes natural seed regeneration.

XLIII. Cleared compartment type.

XLIV. Cleared strip type.

XLV. Cleared group type.

XLVI. Cleared selection type.

XLVII. Types in which lumbering coincides with natural seed regeneration.

XLVIII. Shelterwood compartment type.

XLIX. Shelterwood strip type.

L. Shelterwood group type.

LI. Shelterwood selection type.

LII. Types in which lumbering follows natural seed regeneration.

LIII. Advance growth compartment type.

LIV. Advance growth strip type.

LV. Advance growth group type.

LVI. Advance growth selection type.

LVII. Regeneration of valuable species by natural seed regeneration with, amongst and into companions of weedy character.

LVIII. Pedagogie of the seed forest.

LIX. Cleaning in seed forests.

LX. Weeding in seed forests.

I.XI. Improvement cutting in seed forests.

LXII. Thinning in seed forests. 


\section{SY NOPSIS OF PARAGRAPHS}

Paragraph.

LXIII. Pruning in seed forests.

LXIV. Underplanting in seed forests.

LXV. Key to the forms of seed forests.

LXVI. Critical remarks on seed forests.

LXVII. Seed forests by species.

\section{CHAPTER III.}

\section{The Sprout Forest.}

LXVIII. Genesis of the sprout forests and its types.

LXIX. Pedagogie of the sprout forests.

LXX. Key to the forms of sprout forests.

LXXI. Critical remarks on sprout forests.

LXXII. Sprout forests by species.

\section{CHAPTER IV.}

\section{The Composite Forest.}

LXXIII. Genesis of the composite forest and its types.

LXXIV. Pedagogie of coppice under standards.

LXXV. Key to the forms of coppice under standards.

LXXVI. Critical remarks on coppice under standards.

LXXVII. Coppice under standards by species.

\section{CHAPTER V.}

Propagation of Forest Products Other Than Wood and Timber. LXXVIII. Raising of forest by-products.

LXXIX. Combination of sylviculture and agriculture. 



\section{SYLVICULTURE}

\section{CHAPTER I}

\section{FOUNDATIONS OF SYLVICULTURE}

\section{Paragraph I. Introduction.}

"Sylviculture" comprises all human activities by which trees, wood, bark, and any other forest product imaginable are raised and tended. Sylviculture is the art of the second growth, essentially.

Sylviculture was practiced, in ancient days, for park or for orchard purposes. The first writings on Sylviculture proper appear in the so-called "House Father Literature."

Sylviculture as a branch of forestry was developed by George L. Hartig, Henry von Cotta, and Christian Hundeshagen, a hundred years ago.

European standard books on Sylviculture, of a modern character, are those of Charles Heyer (adapted by Sir Wm. Schlich and Richard Hess), by Charles Gayer, by Henry Mayr, and by WagnerTuebingen.

For America, the teachings of European Sylviculture are of no more direct use, at the present time, than Asiatic teachings might be. The economic and the climatic differences between the various countries are such as to require different methods of Sylviculture in each of them. Nevertheless, the ecologic principles underlying the practice of Sylviculture are identical all the world over.

The planting of forests, on a large scale, is out of the question in America, for the time being. The expense of planting an acre of land in this country exceeds frequently the price at which an acre of merchantable forest may be purchased. The modern owner of woodlands is not far-sighted enough-possibly not credulous enough-to anticipate the arrival of German prices of timber for a time at which the plantations now started will have developed into merchantable trees.

Assuming that the trees will be as valuable by 1980 , in this country, as they are to-day in Germany, France and England, 
forest planting should be, at least, as remunerative in this country where soil values are low, as it is in the old country where soil values are high.

In Germany, too, the production of a second growth by human aid was not thought of so long as timber and fuel wood had little value.

When the value of a product increases, arrives the time at which it is wisdom to produce it.

Sylviculture will be practiced in the United States, to begin with, here and there, on lands where the conditions for it are favorable. As the years go past it will expand all over the woodlands of the United States.

Sylviculture considered as a branch of the science of forestry comprises the following themes:

A. Ecologic principles, facts and definitions.

B. The genesis, or the birth of the forest.

C. The pedagogie, or the tendance of the forest.

D. The sylvical forms of the forest.

"Genesis," in the true meaning of the word, is the act of producing, or giving birth or origin, to anything. The term "genesis" is also applicable to the theories, explanations or accounts of the origin of anything.

"Pedagogie" comprises the principles and rules pertaining to the training of the young.

The terms "forest genesis" and "forest pedagogie" have not met with a favorable reception by the eritics of the first and second edition of the present book. The author continues to use the two terms, for lack of better substitutes, in his lectures at the Biltmore Forest Schonl and in this third edition of his "Sylviculture."

In the discussion of themes $\mathrm{B}, \mathrm{C}$, and $\mathrm{D}$, a distinction is made between the treatment of:

1. Seed forests.

2. Sprout forests.

3. Composite forests.

\section{Paragraph II. Ecologic factors and their in- fluence on the sylva.}

A. Definition.-Plant ecology is a branch of botany showing the dependence and adaptation of plant forms and plant life on and to the surrounding local factors (climate, soil, etc.). 
B. Natural laws govern the organization of the species and regulate the communal life (symbiosis) and messmateship (commensalism) of individuals with their own kin, with relatives and with other plants belongings to the same household and feeding at the same table.

\section{The most important ecologic factors are:}

I. Air. Oxygen, nitrogen and carbonic acid, the main components of air, are essential for plant life. The relative proportion of the two integral parts, $79 \%$ N., $21 \%$ O., varies but little with altitude, latitude and elevation. Salt particles in the air near oceans and sulphuric acid in the air near smelter works are injurious to plant life.

II. Light. Intensity depends on:

Season.

Latitude.

Altitude.

Direct insolation is said to be, on the whole, of less importance than diffused light (excepting polar regions).

Light is not required for germination of seeds. Without light, however, there is no assimilation, and hence no possibility of tree life. Assimilation increases with increasing intensity of insolation; excessive insolation is, however, destructive. For each species, and for each stage of its growth, there exists a certain optimum, minimum and maximum of insolation with reference to the possibilities of its success. The damaging influence of excessive insolation is prevented by the inner organization of the plant.

The duration (number of days) of insolation is as important as the intensity of insolation. Within the individual tree the lower branches are killed gradually, being overshadowed by new upper branches. Without light no bud; without bud no leafing branch; without new leaves annually formed no limb can live.

Within one and the same species a tree once acquiring superiority over its neighbors is apt to retain superiority until death. Since it enjoys more light, it assimilates better.

Within rival species, owing to a greater sensitiveness of chlorophyl and thanks to a more favorable inclination, form and position of the leaves, some species exceed others in assimilation and vitality under the same influx of light. Shade bearing are such leaves as assimilate sufficiently (so as to bear buds at the axils) in spite of the fact that but little diffused light chances to strike them.

Many dicotyledonous trees form a so-called "leaf mosaic," the lower tiers of leaves fitting themselves into the interstices of light 
left in the upper tiers. Many leaves alter their inclination toward the sun according to the hourly degree of insolation (photo-metric movement). The epidermis of light demanding and sun-exposed leares is heary, leathery. The leaves of shade bearers are thin and wither quickly when picked. Light demanding leaves are often shining, reflecting and whitish, so especially in tropical countries, and the leaf stomata are deeply sunk into the surface. On the same tree, leaves growing in the shade are darker than those growing in the light; old leaves darker than young ones.

The formation of spines and thorns indicates a sun plant; hair or down are usually found in light demanders more than in shade plants.

\section{Heat.}

For each plant and for each step of its development can be determined a minimum, optimum and maximum of heat required or allowed. Withont heat, growth is impossible, since cell division is impossible. The formation of chlorophyll, breathing, assimilation, germination, flowering, fruiting and transpiration depend on heat. The distribution of the genera is governed, pre-eminently, by heat.

For some polar plants, life is possible below 32 degrees air temperature Faht. As a rule, however, plant activity begins to be observable at 50 degrees Faht.

The maximum of heat compatible with plant life generally lies below 115 degrees Faht. Excess of temperature over maximum is more disastrous than deficiency of heat below minimum. Plants, however, temporarily fortify themselves against periodical extremes:

1. By non-freezing cell contents.

2. By reduced water contents (seed, rosin).

3. By lignification.

4. By dropping leaves during winter or during period of excessive drought.

5. By adequate covers (bark, hairs, bud scales, layers rich in air cells, reddish color, wrappings formed by last year's leaves). These covers, at least, allow the plant to escape the dangers of rapid changes of temperature.

Short periods of vegetation and long periods of rest result from deficient heat. Hence no annual plants in polar regions. Short shoots, evergreen leaves, preparation of flowers in year preceding fruit are characteristic of a polar fiora. In tropical countries there are no periods of rest unless determined by periods of drought. 


\section{THE ART OF THE SECOND GROIVTH}

\section{Moisture of air and precipitations.}

Water is at hand

a. to increase the toughness of wood (imbibition water of cell walls) ;

b. to allow of solution of cell contents (cell sap);

c. to serve as plant food, through assimilation;

d. to allow of osmotic movement of sap;

e. to assist in photometric movement of leaves (through swelling and irritation);

f. to reduce rapidity of change of temperature by evaporation.

Some lichens survive a process of absolute drying. Lack of moisture causes crippled growth, and frequently subterranean forests (mesquit).

After Henry Mayr, the minimum of moisture compatible with tree growth is two inches of rainfall and fifty per cent. of relative humidity during the period of vegetation.

Phanerogamous plants are unable to absorb water directly through the epidermis, obtaining it instead through the spongiolæ of the roots and, in gaseous form, through the stomata of the leaves. Mosses and lichens, however, absorb water directly through the epidermis. The hygroscopic power of a dead cover of mosses on the ground equals that of a live cover.

Wet climate creates evergreen woods (Pacific coast and antarctic forests of South America).

A dry climate gives rise to annual species, to a distinct period of rest, to rapid flowering and fruiting.

Precipitations equally distributed over the twelve montlis of an entire year and precipitations falling during a few weeks result in entirely different floras. Rain in summer stimulates growth much more than rain in winter. De Candolle divides our globe according to moisture and heat and on the basis of the resulting floral differences, into five regions.

1. Hydromegathermal region (water great heat). Mean annual temperature over 68 degrees Faht. (Amazon river region, wet tropical zone).

2. Xerophilous (dry loving) region. The region and borders of arid deserts, prairies, sunny slopes, etc., exhibiting a flora very modest in moisture requirements.

3. Mesothermal (medium heat) region, having mean temperature of 59 to 68 degrees Faht. (northern Florida, etc.).

4. Microthermal (little heat) region of 32 to 59 degrees Faht.

5. Hecistothermal (least heat) region of less than 32 degrees Faht. 
The most important representative of a xerophilous eharacter is the lellow Pine. The hecistothermal zone shows Spruces, Birches, Cottonwoods.

\section{Wind.}

Wind brings moisture and drought, heat and cold; it covers or uncovers vegetation with sand or snow drifts, tumbling, at prior geographical eras, whole mountains into the valleys (Loess formation). Severe wind dwarfs tree growth and forces branches to grow in leeward direction only. The influence of a slight obstruction, preventing the access of wind at high latitudes, is splendidly illustrated by the growth of Spruce and Fir on Pisgah Ridge. On high mountains, the possibility of growth is often entirely determined by wind.

Wind is responsible for the crooked growth of Catalpa in the prairies, the shake in Hemlock on exposed ridges, the fungus diseases in many trees.

The rainfall and, consequently, the existence of forests depends on the moist sea winds supplied by the Pacific, the Atlantic, the Gulf and the Great Lakes. A cross-section through North America at the latitude of Lake Michigan and Portland, Oregon, shows the inter-dependence between the lowest gaps in the mountain chains and the forest on the next mountain chain lying to leeward. For instance: lowest gap in Coast Range at 3,000 feet above sea level; no forest in Cascades below 3,000 feet; lowest gap in Cascades at 4,000 feet above sea level; no forest in Blue Mountains below 4,000 feet; lowest gap in Blue Mountains at 5,000 feet above sea level; no forest in Rockies below 5,000 feet.

The east slopes of the Coast Range, Cascades, Blue Mountains and Rockies, below the gaps in these chains of mountains, show little or no forest, and the lowlands to the east of the mountain chains are deserts and prairies.

Moist sea winds, after passing one chain of mountains allow the forest to grow on the next chain only above the altitude of the gaps in the first chain.

ricea alba and dwarf pines like Pinus pungens show great strength in resisting wind. In the IVest Tsuga mertensiana, Pinus albicaulis, further Western Juniper rank first among the trees braving severe storms.

Wind is essential for the breathing and for the perspiration of leaves and bark; for driving pollen on stigma to fertilize the seed; for trimming the branches, thus forming clear boles; for distributing seed. The investigations conducted by Fliche (French forester) 


\section{THE ART OF THE SECOND GROIVTH}

have yielded, however, the astonishing result that winged seeds travel much more slowly than heavy seeds coveted by birds. Fliche gives the following number of years as required by trees traveling from Nancy to Paris, a distance of 160 miles:

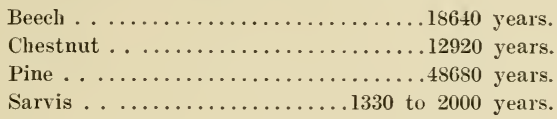

\section{Structure of soil.}

Soil consists of natural rock; or of rock disintegrated under the influence of water, frost, heat, oxygen, carbonic acid, lichens, bacteria; or of material deposited by water, wind or glaciers.

The components of soil are:

a. Soil skeleton, large grains, principally quartz and stones.

b. Soil flesh, minute semi-soluble particles,- the mud of the rivers.

c. Soil fat, the humose particles giving the soil a dark color.

d. Soil blood, the air and water, filling the pores of the soil. The size of the pores determines the capillary capacity.

According to the resistance which soil offers to spade or plow, we distinguish the following classes:

Light soil;

Loose soil;

Binding soil;

Heavy soil;

Stiff soil.

\section{Air in the soil.}

Roots require oxygen for breathing. Like fish, they die from a lack as well as from a superabundance of oxygen. Subterranean air is rich in earbonic acid exhaled by roots, fungi, bacteria, animals. Swamp soil contains little air. Hence no species find a living in swamps but those which have large inner air ducts.

Prairial soil is naturally so compact that it contains little oxygen.

\section{Water in the soil.}

\section{It occurs:}

a. Chemically bound to minerals and salts.

b. Absorbed by the hygroscopicity of the soil.

c. Raised by the capillary power of the soil.

d. As ground water,-lakes, swamps, brooks being merely areas of open ground water.

The size of the pores and the presence of humus govern the 
intensity and rapidity of water obtention and retention. Sand, for instance, allows water to enter into its large pores quickly, but gives it up rapidly as well. Wet, moist, fresh, dry and arid soil are distinguished.

The degree of the wetness of the soil is of the utmost importance for tree growth. At its Southern limit, a species may grow but along watercourses. The water in the soil dissolves the mineral salts and seems to be of great influence on the bacterial life in the soil.

\section{X. Heat in the soil.}

It is derived from the earth's own temperature, from chemical processes in the soil (notably fermentation) and from the sun rays. In the latter case, the angle of insolation, the duration of insolation, the heat capacity, the color, the porosity of the soil and its vegetable cover serve as influencing factors.

A cold root has no pumping power. Fine root fibres die from temperatures which fine pranches easily withstand. The actual influence of the heat in the soil on tree growth is practically unknown. The opening of the buds in spring and the fall of the leaves in autumn are probably connected with the thermic changes occurring in the various strata of the soil.

\section{Depth of soil.}

Flat rooted species easily obtain the superiority over taprooted species on shallow soil. Tree roots, however, are not apt to penetrate to a depth greater than six feet. Shallow soil increases danger from fire, drought, storm. A tap rooted species, planted on shallow soil, produces but a stunted form. Shallow soil is well adapted to the coppice system, in case of broad leaved tap rooted species.

\section{Food in the soil.}

A tree, like a crystal, is composed of various chemical elements. The available amount of that necessary element which happens to oceur in the relatively smallest degree determines, in both crystal and plant, the rate of growth actually taking place (Liebig's law). The superabundance of one component, even of a necessary component, prevents, on the other hand, the local existence of many species.

The ten necessary elements found within a plant in solid, liquid or gaseous condition are $\mathrm{O}, \mathrm{H}, \mathrm{C}, \mathrm{P}, \mathrm{Fe}, \mathrm{K}, \mathrm{Mg}, \mathrm{Ca}, \mathrm{N}, \mathrm{S}$,

"Roots search food as if they had eyes," is a rule easily proven in any nursery. 


\section{Species of soil.}

a. Rock. Most important rock formations are: Granite, gneiss, limestone, sandstone, slate and trap.

Vertical stratification facilitates decomposition and tree growth. The various species of rock differ in hardness, porosity, heat conduction, and above all in soluble mineral contents.

b. Quartz sand. Quartz sand is unproductive when pure, since silicic acid fails to be digested by the roots and fails to react with the acids and radicals usually found in the soil. Quartz sand is loose, has small hygroscopicity, small capillarity and small heatretaining capacity. It is hot during the day and cold during the night.

c. Lime. Lime when pure is a poor soil, although not quite as dry and hot as sand. Lime, however, mixed with loam and clay (so-called marl) forms an extremely productive soil.

d. Clay. Clay has great absorbing and hygroscopic power. It is wet and cold. Main components are aluminum-silicates.

e. Loam. Loam is a mixture of sand and clay-the usual soil in agriculture and forestry. It is usually colored by iron (red loam at Biltmore). We speak of a sandy loam or of a loamy sand according to the prevalence of one or the other component. Loam soil exhibits a happy medium of qualities favorable to tree growth.

f. Humus. Humus results from the decomposition of vegetable and animal matter under co-operation of bacteria, fungi, rain worms (Darwin), larvae. Humus forms a solvent of mineral plant food. A bad conductor of heat and cold, it prevents rapid changes of temperature in soil, has great hygroscopicity and great waterretaining power and is a preventive to evaporation of soil moisture.

Mild forest humus shows a basic reaction, whilst the sour humus of the swamps shows an acid reaction.

Unfavorable to the trees is the dust humus formed by many Ericaceae.

\section{Physical versus chemical qualities of soil.}

Agriculture withdraws food but from the top layer of the soil. It deprives that top layer of its rarest and most valuable components, by removing an annual crop of grain excessively rich in nitrates, phosphates and potash. The porosity, and through it the water capacity and the heat capacity of the soil, are readily controlled on the field by the plow. It is necessary in agriculture, in the long run, to return to the soil in the shape of fertilizer as many pounds of nitrates, phosphates and potash annually as have been removed in the shape of crops from a given acre of land. 
The productiveness of agriculture depends, above all, on the chemical qualitics of the soil tilled. A erop of trees, on the other hand, takes from the soil but little, since the tree consists mainly of $\mathrm{C}, \mathrm{O}, \mathrm{H}$, or since wood is nothing but air solidified by sunshine. The phosphates, nitrates and potash absorbed by the tree are returned to the soil by the fall of branches, leaves, seeds, flowers, etc.

The traces of chemical fertility locally removed in the shape of logs are, in addition, counterbalanced by the decomposing influence on the rock exercised by roots, root-bacteria, and enzyms.

Hence it is not likely that a rotation of crops, such as is required in agriculture, has any advantages in the case of forestry. In primeval woods, we know that Nature allows a species to sneceed itself. It must be admitted, however; that a short-living crop of weeds (fire cherries, aspens, briars, herbaceous weeds) intervenes frequently between successive generations of trees.

The physical qualities of the soil preeminently influence the tree species and the rate of its growth. The chemical qualities of the soil play the most potent role in the case of agricultural species.

Soil fit for agriculture is not necessarily a good forest soil (prairies). Soil fit for forestry (strong North slopes) is often utterly unfit for farming.

XIV. Soil covers.

Soil covers are either dead or living. Dead soil covers are snow, debris of leaves and twigs. Living soil covers consist of mosses, grasses, etc.

After K. Boehmerle, a living moss-cover retards the growth of young trees, during a dry season. The moss absorbs the larger part of the precipitations. During a wet season, the moss-cover may be useful by storing the surplus of moisture. It seems advisable to remove the moss from the woods in rotations of about three years. Compare C. G. F., 1910, page 523 .

Snow keeps the soil warm, prevents rapid changes of temperature, prevents young plants covered by it from perspiring, prevents heaving of plants by frost.

The debris on the ground feed millions of animals and fungi; they harbor, on the other hand, mice, larvae and other enemies of plant growth. Debris frequently prevent reproduction from selfsown seed and increase the severity of forest fires. Living, as well as dead soil covers, influence the evaporation of moisture, the porosity of the soil and the drainage. 
XV. Life in the soil (Compare Swiss L. F. F. 1904, May and June).

The soil lives like a plant or an animal, since it shows continuous ehanges of form and of composition. Very little, however, is known of the life and the interdependence of millions of live individuals found in the soil. Certain it seems that tree growth is bound on the presence of certain fungi and bacteria living on the roots (Mycorrhiza, important, notably, for shade-bearing trees).

Most important are the bacteria capable of digesting the nitrogen of the subterranean air. Leguminous plants (Clover, Black Locust) are beset with root knobs, containing bacteria busily engaged in the assimilation of nitrogen. The hyphae of a fungus called Frankia play a similar role on the root knobs of Alder and Sweet Fern. After P. C. Mueller, Spruce will grow on poor sand lacking nitrogen if Pine is mixed with it, furnishing nitrogen through its mycorrhiza.

At Biltmore, Cherry plantations have succeeded surprisingly well when there was an admixture to them of Yellow Pines.

The maximum number of bacteria is said to be found two feet below the surface of the ground, and none exist below six feet. The number of bacteria per pound of soil varies from one hundred million to two hundred and fifty million.

Important, too, in plant ecology is the life of the larger animals (worms, insects, nematodes, centipeds) changing the regetable matter of the soil into manure proper, mixing mineral soil and vegetable matter, increasing the porosity, drainage and aeration and neutralizing the acids of the soil. Shade, protection from wind and sufficient moisture are beneficial to animal life in the soil.

\section{Paragraph III. Influence of the sylva on the ecologic factors.}

The influence exerted by the forest on the local climate (heat, air, precipitations, etc.) is dwelt upon in the lectures on forest policy.

Whilst the ecologic factors shown in the previous paragraph exhibit the important influence which the soil has on the tree, there exists at the same time, although to a lesser degree, an influence of the tree on the soil. This influence is invariably such as to 
facilitate life to the tree itself and to its progeny. The production of humus is the main source of that influence.

Governing factors are:

A. Leaf canopy overhead. Evergreen as well as deciduous woods return to the soil by the leaf fall annually a large amount of dead matter readily assimilable. Shade bearers furnish a better humus than light demanders, excluding, at the same tine, intensive insolation, so that the decomposition of the leaf carpet and the evaporation of the soil moisture is favorably retarded.

A humus formed by Beech, Maple and Chestnut is considered especially good. Beech is called abroad, justly or unjustly, the "Mother of the Forest," owing to its soil-improving qualities. The leaf canopy is particularly dense during the thicket and the polewood stage. Even light demanders, whilst young, improve the fertility of the soil. At a higher age, when the light demanders place themselves far apart one from another (say less than 100 trees per acre), the humus on the ground is destroyed frequently, being replaced by a dense and impermeable matting of grasses or shrubs.

Amongst the conifers, Yellow and White Pine seem to furnish the best humus. Spruce humus is too waxy.

\section{B. Rate of disintegration of leaves.}

This rate depends on insolation, on heat capacity of soil (sand versus clay), on atmospheric humidity. Usually the decomposition of the leaf fall takes place within two or three years. The thin leaves of the shade bearers decompose quicker than the heavy leaves of the light demanders. The atmospheric moisture of high altitudes causes an accumulation of large quantities of leaves. In the tropics, there is little litter on the ground.

\section{Root system.}

It is the decaying root which allows the precipitations to trickle down to the lower strata of soil. Hence tap rooters seem more efficient than flat rooters in converting a rapid surface drainage into a slow underground drainage. Decomposing the rock by chemical action, the tap root forces it to yield its soluble salts.

D. Soil improvement through root-bacteria and fungi.

The upper layers of forest soil are densely peopled with the hyphae of basidiomycetes, living on humus. Leguminous trees (Locust, Kentucky Coffee tree, etc.) by their root-bulbs increase the fertility of the soil, and the Alders seem to act in a similar manner. On abandoned fields in Pisgah forest the soil is improved by 


\section{THE ART OF THE SECOND GROWTH}

Sumac, Sassafras, Locust, etc. These species act as ushers for more exacting forest growth, improving the physical conditions of the soil. Little is known about the nature of the improvement.

\section{Paragraph IV. The North American sylva.}

The northern limit of the forest coincides with the isothermal line of 30 degrees Faht., which lies on the west side of the continent at 65 degrees latitude in Alaska (under influence of the Japan current), and on the east side at 57 degrees latitude in Labrador and at the Hudson Bay.

The tropical forest shows no seasons. Its species are evergreen. In the United States it is found at the extreme southern point of Florida and of Texas.

The sub-tropical forest is characterized by the evergreen broadleaved trees, and is the zone of rice and oranges, extending in eastern North America to 35 degrees, in western North America to 40 degrees, latitude.

The moderately warm forest region is the zone of the broadleaved deciduous trees, of corn, vine and wheat.

The moderately cold forest region is that too cold for the production of corn.

In North Carolina a trip from the coast to the high Balsams leads the traveler from the northernmost limit of the sub-tropical through the moderately warm forest region into the southernmost limit of the moderately cold forest region which sets in at about 4,000 feet elevation.

The following table shows the composition of the forest of the United States and of Canada, under the influence of the climate:

Percentage of forest area occupied by:

In United States. In Canada.

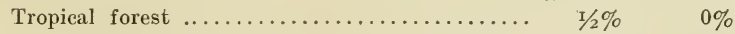

Sub-tropical forest $\ldots \ldots \ldots \ldots \ldots \ldots \ldots \ldots \ldots \ldots \ldots \ldots$

Forest of the moderately warm zone........ $75 \% \quad 10 \%$

Forest of the moderately cold and alpine zone... $\quad 91 / 2 \% \quad 90 \%$

The United States contain two big and one minor forest region, namely the

Atlantic forest region;

North Mexican forest region;

Pacific forest region. 
The Atlantic and the Pacific forest join under the influence of the Hudson Bay winds in the provinces of Saskatcliewan and Alberta. There are no prairies proper north of 52 degrees latitude.

\section{A. The Atlantic forest.}

I. Eastern tropical forest. Mahogany ocenrs only as a small tree, Palms and other typically tropical orders (Sapotaceae, Ebonaceae, Euphorbiaceae, Verbenaceae) compose the forest. It must be remembered that Southern Florida exhibits but the extreme northern occurrence of the tropical forest.

II. Eastern sub-tropical forest. It shows evergreen Oaks, Magnolias, Persea, etc., besides the Pines, the soil being too poor for the formation of a large wintergreen broad-leafed forest. The winter temperature averages 53 degrees Faht; precipitations are heary; relative humidity is 75 degrees. Sabal palmetto is a characteristic weed. Bald Cypress and Cuban Pine are characteristic trees of the region. Among the other Pines, the Long Leaf Pine is the most important, associated in the north and west with Pinus clausa, echinata, taeda, serotina, glabra. Liquidambar, Nyssa and Fraxinus platycarpa occur in swamps at the edge of which Southern White Cedar appears frequently.

III. Eastern winter bald forest of the moderately warm zone. It is fringed at the south, north and east by a broaci belt of Pines, which belt connects this region at the south with the sub-tropical forest, at the north with the Fir and Spruce forest of the moderately cold zone. It is divided into a northern and a southern half by the 39 th degree of latitude. Each half shows an Atlantic, a central and a prairial sub-region.

a. South Central Sub-region. Traversed by the Mississippi, the sub-region is characterized by high temperatures, large precipitations and fine soil, which allow of the best development of broadleaved woods found in the world. Twenty-three Oak species, eight Hickory species, two Walnuts, Buckeyes, Chestnut, Gums, Cottonwoods, Yellow Poplar, Sycamore, Beech, Maple, Elm, Red Cedar, etc., stand in a dense undergrowth formed by Dogwood, Kalmia, Rhododendron, Hazel, Hawthorn, Buckthorn, Witch Hazel, etc.

In this sub-region the heavy seeded broad-leaved trees obtain the maximum of size, quality and number of species at altitudes running up to 3,000 feet. Higher up the number of species diminishes. At 5,000 feet only Red Oak, Chestnut, Beech, Buckeye, Sugar Maple (resembling north central subdivision) are found, and 


\section{THE ART OF THE SECOND GROIVTH}

at 4,000 feet the Spruces and Firs (southernmost sentinels of moderately cold zone) set in.

b. South Atlantic Sub-region. It comprises the Eastern foothills of the Alleghanies (Piedmont Plateau) and part of the Coastal Plain. Temperature $3 \frac{1}{2}$ degrees Faht. less, soil poorer, precipitations less abundant than in the South Central sub-region, hence much Pine (taeda, mitis, rigida, virginiana). Only ten Oak species; White Cedar swamps; broad-leaved flora otherwise as in South Central, but of rather inferior development.

c. South Prairial Sub-region. Extending from the 92nd to the I02nd degree of longitude, the forest appears poorer than the annual temperature and the annual rainfall seem to indicate; a discrepancy between cause and effect, possibly due to forest fires. West of the 95th degree of longitude, Oak, Ash and Walnut occur along rivers, especially on Eastern banks. Oak also appears scattered through the depressions.

d. North Central Sub-region. Precipitations coming from South as well as from North very abundant. Average winter temperature 30 degrees Faht. Quick change of temperature. The light-seeded, broad-leared species reach maximum in this section. White Pine and Hemlock, six Maples, five Birches, Elms, Lindens, Ashes, Butternut, Red and White Oak compose the forest.

e. North Atlantic Sub-region. Plenty of moisture, the mountains being close to the seashore, but not so much as in Lake states. Average winter temperature 34 degrees Faht. at seashore. Pinus rigida and echinata, Beech, Birch, Chestnut, Maples, often replaced by Poplar and Willow. Spruce sets in at altitude exceeding 1,000 feet, accompanied by Hemlock, White Cedar, Red Cedar, White Pine and Tamarack.

f. North Prairial Sub-region. Dry summers, blizzardy winters and more sandy soil. No Hemlock. Red Pine and Jack Pine intruding from North. Scrub Oak openings. On best soil still good development of Linden, Maple, Elm and Birch. White Pine of poorer quality than in sub-region " $d$. "

\section{- IV. Eastern Evergreen Forest of the moderately cold zone.}

The majority of this zone lies in Canada, in the northern Lake states and in Maine. It occurs in North Carolina at 5,000 feet elevation; in the Adirondacks at 2,000 feet; in Maine at sea level.

The region occupies a big belt stretched across the continent, so that the western and eastern flora join hands in it. A typical tree of this region, the White Spruce, often forms large pure forests. 
Other species of the zone are Red Spruce, Black Spruce, Balsam-fir, Cotton-woods, Canoe Birch, Hemlock, White Cedar and Tamarack, the latter here obtaining its optimum.

\section{B. The North Mexican forest.}

The North Mexican flora intrudes, coming from Mexico, the states of Arizona and New Mexico. It is small in area, but interesting botanically. Forest not possible save at altitudes excceding 5,500 feet. Forest proper-dense forest-but at 8.000 fcet.

\section{North Mexican sub-tropical forest.}

Characterized by Cactus, Yucea, Agave and Mesquite (Prosopis). Evergreen Oaks in moist valleys. Madrona (Arbutus), a beautiful tree, on sunny slopes often mixed with Manzanita (Acrostaphyios pungens).

\section{North Mexican forest of the moderately warm zone.}

This zone, very narrow, should contain winter-bald broad-leaved species. The dryness of the soil and of the air, however, does not allow of their occurrence save on moist ground along rivers. Western Walnut, Mexican Ash, Poplars and Willows. The Pines are the leading species of the zone, forming huge forests at altitudes exceeding 6,000 feet elevation. Some of these Pines are northern sentinels from Mexico, others outposts from the States. Important is Pinus Chihuahuana, in Mexico largely used for timber, up to 80 feet high, three feet in diameter, three needles. Pinus Arizonica, a five-needled Pine, occurs at 6,000 feet elevation. Pinus reflexa, locally known as White Pine, occupies moist dells at 8,000 feet elevation. Nut pines at lesser elevations as low brush, notably Pinus edulis, monophylla, osteosperma.

\section{The Pacific forest.}

Typical difference from Atlantic forest lies in the relative lack, not in species but in area, of broad-leaved woods. Tropical forest is absent, possibly due to lack of moisture at low elevations in Southern California.

\section{Pacific sub-tropical forest.}

Occupying Southern California. This zone is devoid of dense forests, the northern edge excepted. Evergreen Oaks, or rather Winter Green Oaks (Pasania densiflora is leafless during dry sum. mer) dot the ground in park-like groves. California Laurel (Umbellularia californica) is a characteristic tree of this region, growing up to 100 feet high. Impenetrable bush thickets cover hot aspects, formed by Leguminosae, Labiatae, Compositae, Rosaceae, etc. The rare and beautiful Montery Cypress along the seashore. 
Sequoia sempervirens in the Coast Range is the biggest tree of the zone, found at its edge. Pinus insignis, known as Montery Pine, is valuable on sand dunes.

Pinus tuberculata (attenuata) occurs most frequently in evenaged woods. Pinus sabiniana, Nut or Digger Pine, valuable for the Indians, of Olive-like appearance, is mixed in the Oak parks and in the Chaparal thickets. Another Nut Pine is Pinus parryana, growing 30 feet high. Pseudotsuga macrocarpa on St. Bernardino range. Eucalyptus and Accacia from Australia, Oranges and Figs from the Orient, were successfully introduced.

II. Pacific forest of the moderately warm zone.

This zone covers the major part of the forests of Oregon, Washington and Northern California. It is characterized by an even annual temperature and high precipitations. The winter bald Oaks are represented in Oregon by Quercus garryana (White Oak), in California by Quercus kellogii (Black Oak). Fraxinus Oregona, Acer maerophyllum, Populus trichocarpa (the biggest Cottonwood of the world) occupy the bottom land along the rivers; further Sorbus, Amelanchier, Crataegus, Prunus, Salix, Aesculus, Alnus, Acer, Negundo, Platanus, Betula. All of these latter species unimportant commercially.

In strict contrast with the Atlantic forest of the same zone, the conifers rule in importance, foremost among them the Douglas Fir (Pseudotsuga taxifolia) which stands temperatures of 15 degrees Faht. easily. Best development on west siope of Coast Range. In the Rockies, it forms short boles, owing to shorter growing season and lack of atmospheric moisture. In Colorado, Arizona and New Mexico occurs a gray variety. In the Sierras it appears as a dependent species. On the Fraser river, a fourth race of Douglas Fir is distinguished.

Pinus ponderosa ( Hellow Pine, Bull Pine). Height and timber quality depend on proximity to Pacific Ocean. Optimum in Sierra Nevada, where trees 300 feet high are frequently found. Very heavy sap-wood. Name ponderosa undeserved. No tree species of the United States occupies a larger territory or shows greater adaptability.

Chamaecyparis lawsoniana (Port Orford Cedar) occupies a small territory close to the Pacific Coast. It does not ascend the mountains to altitudes over 1,500 feet. Heavy shade bearer, splendid reproduction.

Thuja plicata (Red Cedar of the West) up to 170 feet high. Rare in California. Best development in Oregon and Washington 
and Northern Idaho, where it occupies the moister coves. Boles very tapering; shade bearing.

Libocedrus decurrens (White Cedar, Bastard Cedar) on west slope of the Sierras at medium elevations, where the tree is mixed with Abies concolor, Yellow and Sugar Pine. Regeneration eass, often in places previonsly occupied by the Pines.

Pinus lambertiana (Sugar Pine), with five needles in a sheath, specific gravity less than that of Eastern White Pine (Pinus strobus). The biggest Pine of the world. Very large cones. Optimum in Sierras at 5,000 feet elevation; occurs often with Sequoia, Libocedrus, Abies concolor, Yellow Pine, Pinus jeffreyi. The latter, a very close relative of ponderosa and distinguished from it by bluish shoots and needles bent towards the shoots, occupies the lower Sugar Pine belt. It prefers moist ground and reaches but one-half the size of ponderosa.

Mayr groups the above trees as follows, according to their demands on moisture:

Demands on soil moisture:

1. Libocedrus decurrens,

2. Pinus jeffreyi,

3. Abies concolor,

4. Pinus lambertiana,

5. Pinus ponderosa.

Demands on air moisture:

1. Abies concolor,

2. Pinns lambertiana,

3. Pinus jeffreyi,

4. Libocedrus decurrens,

5. Pinus ponderosa.

Abies grandis (White Fir of Northern Pacific Coast). The only fir on Vancouver Island. Optimum at coast in Oregon where it grows up to 300 feet high, standing alongside gigantic Cottonwoods; extends eastward across the Northern Rockies, and is the first Pacific fir met by the traveller going west on the Northern Pacific. Requires moist soil.

Abies concolor (White Fir of Colorado and of the Sierras). Running south to the San Bernardino mountains, where it occupies elevations of up to 10,000 feet. Traversing Nevada, it occurs in Colorado (gardener's variety glauca). It accompanies Sugar Pine and Bigtree. After Muir, always mixed with Abies magnifica, occurring at altitudes ranging between 5,000 feet and 8,000 feet.

Abies bracteata (Santa Lucia fir of high mountains) occurs in Southern California in moist cool dells. 
Tsuga heterophylla (Black Hemlock of low elevations). A fine tree, the progeny of which forms a dense undergrowth underneath Douglas fir. Heavy shade bearer, requiring plenty of moisture, occurring in Alaska, Coast Range and Cascades.

Picea sitchensis (Tideland Spruce). Along coast on moist soil in Washington and Oregon, on dryer soil in Alaska, shade bearing and branchy. Stinging needles. Up to 200 feet high.

Sequoia washingtoniana (Bigtree). Occurring in the Sierras in scattered groups at elevations ranging from 4,000 to 7,000 feet. Enormous seeding capacity and sprouting capacity. Average diameter 20 feet, height 275 feet, age up to 4,000 years.

\section{Pacific forest of moderately cold zone.}

This zone is economically of little importance, although it is the forest zone proper, owing to the impossibility of agriculture within this zone. It is "The Canadian Forest Zone." It lies in the Sierras at 8,000 feet, in the Cascades at 4,000 feet, and in Alaska at seashore. The forests of the Northern Rocky mountains belong to it preferably.

Pinus murrayana (Lodgepole Pine). Shade bearing, in close stands, very branchy, very sappy, retaining cones, easily destroyed by fire, closely related to the Jack Pine of the east. Frequent on old burns, typical for Yellowstone Park, going south to Arizona.

Larix occidentalis (IVestern Tamarack). Splendid lumber tree, often in pure forests, optimum in Idaho, natural regeneration easy, rapid height growth, little sap wood, timber equal to that of Long Leaf Pine.

Pinus flexilis (Limber White Pine). More branchy and much shorter than eastern White Pine; forms open forests on south slopes of Sierras and in Nevada at 7,000 feet elevation; it extends from Montana southward to Colorado.

Pinus monticola (Western White Pine). In Cascades, British Columbia, Idaho, Montana, in the latter state more on slopes draining westward.

Abies nobilis, amabilis, magnifica, the Red Firs of the west. Magnifica known in California as Larch. The two first named of ten associated with Abies grandis and more frequent in Washington and Oregon than in California. Amabilis extends into Alaska. Red Firs are lacking in the Rockies. Needles are dark.

Picea engelmanni (White Spruce). At home in middle and southern Rockies, on northern slopes at altitudes averaging 10,000 feet.

Picea parryana (Colorado Blue Spruce). Needles very pointed and stinging, of a bluish tint. Occupies moist ground. 
IV. Pacific forest of the Alpine region.

Typical trees are:

Pinus albicaulis (Dwarf White Pine), occurring in the Cascades and the Northern Rockies.

Pinus balfouriana and aristata (Fox-Tail Pine), White Pines found in California at 8,000 feet to 12,000 feet elevation; twigs thin, retaining needles for many years.

Abies lasiocarpa (Balsam). At edge of iree growth but a shrub. In Colorado at lower, warmer situations a valuable tree. Occurs in all states of the west.

Larix lyallii (Larch of British Columbia). Oceurs here and there in Washington, Idaho and Montana, at very ligh altitudes.

Tsuga mertensiana (Hemlock). A storm-battered Hemlock, at high altitudes in Sierras, Cascades, Montana. A branchy tree up to 100 feet high, inaccessible and hence of no value.

\section{Paragraph V. General definitions and explan- ations.}

A. By the term "wood" is understood an aggregate of trees of such uniform eharacter that it can be subjected to the same manner of treatment. In the American virgin forests, "woods" are rare. As a matter of fact the term "woods" as well as the term "forests" has no definite meaning in America. A forester should keep in mind, however, that a plantation or a natural regeneration, whatever its age and its condition, must be elassed under the heading "forests."

A "group" of trees consists of even-aged specimens of the same species and is larger than a bunch, clump, or cluster. No recognized definitions of the term "group" and "clump" are at hand, unfortunately, based on the space or the acreage covered by them as units. Groups, as understood in the following pages, are distinct aggregates of trees covering $\frac{1}{10}$ to 4 acres.

Seed forests, or high forests, are forests composed of specimens originating from tree seeds.

Sprout forests, or coppice woods, are forests composed of specimens originating from sprouts, stoolshoots, rootsuckers, layers, cuttings, and not from the seeds of the trees.

Composite forests are forests recruited from tree seeds as well as from stumpsprouts. The composite forest is a mixture or a zombination of the seed forest and of the sprout forest. 
B. Pure forests, pure woods, pure groups or bunches are such as contain one timber species only, 5 per cent. admixture being permissible. Species able to form.pure forests are termed gregarious or ruling species, sub-divided into distinctly ruling species, which are usually found in pure stands, and conditionally ruling species, which are occasionally found in pure stands.

I. After Drude, the participation of a species as a mess-mate at the forest table is expressed by the following terminology:

a. Social species, denoting the main character, the striking feature (in numbers and volume) of the forest; the rank and file of the forest; like;

b. Gregarious species, occurring in clumps and groups, island

c. Copious species, interspersed with others, the degree of frequency being interpreted by exponents, e. g., eopious ${ }^{3}$, copious ${ }^{2}$, copious $^{1}$;

d. Sparse species, occurring isolated and in single specimens;

e. Solitary species, very isolated and very rare.

II. The ratio of the participation might be expressed in per cent., as follows:

Social, forming $60 \%$ and over of growing stock.

Gregarious, forming $40 \%$ and over of growing stock.

Copious, forming $20 \%$ and over of growing stock.

Sparse, forming $1 \%$ and over of growing stock.

Solitary, forming less than $1 \%$ of growing stock.

Intermediate stages might be indicated by a combination of the given designations, e. g., "social-gregarious."

III. The configuration of the ground and the rapidity of its change influence vitally the possibilities of a species as a component of the forest.

IV. Species which are not "ruling," or which are locally not "ruling," are called "dependent" species.

A species might be ruling in North Carolina, while it is dependent in South Carolina. The distribution of the species is limited by its demands on soil and climate. Far away from its center of distribution, a species is likely to be dependent.

V. The ruling species in the south are: Long Leaf Pine, Bald Cypress, Loblolly Pine, Short Leaf Pine, Sweet Gum, Post Oak, Cottonwoods, Chestnut.

The ruling species in the west are: Lodgepole Pine, Pinus ponde- 
rosa, Douglas Fir, White Fir (Abies grandis), Engelmann's Spruce, Western White Pine, Port Orford Cedar, Redwood, Sitka Spruce.

VI. The meek species are those that conquer the globe. With the inroads of civilization on the fertility of the soil, and especially on the water capacit $\dot{y}$ of the soil, these meek species obtain additional chances to supersede the exacting species.

\section{Weapons of the species in the struggle for exist- ence are:}

I. Shade-bearing qualities.

II. Modesty as regards the fertility the depth, and the aeration of the soil, further as regards the moisture and the heat during the period of vegetation.

III. Power of resistance to storm, sleet, snow, late and early frosts, droughts, fire, etc.

IV. Immunity from forest insects and forest fungi. of all.

V. Longevity.. Oak lives longer than Beech; Sequoia longest

VI. Reproductive power, especially reproductive power from stumps or roots, frequency and richness of seed years.

VII. Portability and sensitiveness of seeds; number of enemies of seeds; germinating percentage of seeds.

VIII. Rapidity of height growth in early youth.

D. Density of stand. Every ruling species shows a particular density of cover and a particular ramification during every stage of its life, when grown in pure forests.

I. Density of leaf cover overhead.

a. The form of the crown of the individual depends on sideshade, topshade, neighborly friction and quality of soil.

b. Natural regeneration causes a greater density of cover than artificial regeneration, certainly during the thicket and pole stage. Other influencing factors are: quality of the soil, age of the forest, inroads by snow break, wind fall, fire, deer, fungi, insects.

c. A dense canopy overhead produces clear-boled timber and allows of a heavy layer of humus on the ground. The method of regeneration distinctly influences the value of the timber to be formed.

\section{Number of trees per acre.}

Under normal conditions an acre of pure forest contains the more specimens of equal height or diameter, the hetter the quality of the soil and the better the climate; and the more specimens of 
the same age, the poorer these factors are. For example-Yellow Pine Forests:

Number of trees per acre.

Soil. Boles 75' long. Diameter 12". Age 60 y's.

$\begin{array}{rrrr}\text { I quality . . } & 320 & 240 & 380 \\ \text { II quality . . } & 240 & 215 & 469 \\ \text { II quality . . } & 190 & 190 & 540\end{array}$

During the pole stage and tree stage, shade bearers exhibit per acre of ground about $50 \%$ more trees than light demanders.

The following eurve illustrates the interdependence between age and number of trees per acre:

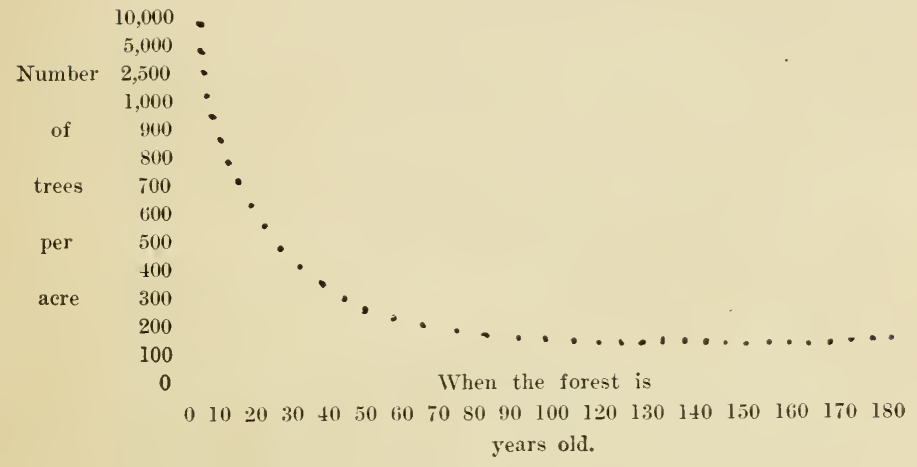

III. Growing space of a tree.

In their earliest youth all species stand or even desire a dense cover overhead. When the food supply stored in the seed shell is consumed, however, the seedling requires light to digest its food. With increasing age, the tree boles getting longer, the crowns rub and beat one another intensely, oscillating in the wind. As a consequence each crown is surromnded with an air space, the relative width of which depends largely on the length anil the flexibility of the bole. It might be stated that the growing space of a tree is a function of the square of the gradually lengthening bole.

Trees differ in the ease with which warring neighbors lose their buds and shoots. Oak, for example, loses its May shoots easily, whilst Beech, struggling with Oak, loses but a few leaves along its 
flexile swaying twigs. In heary storms Yellow Pine often loses whole branches. White Pine, on the other hand, does not lose its shoots (topshoots) easily, unless they are whipped in the wind by the stiff branches of Black Locust, Beech, Maple, Aspen, etc., forming a superstructure above it. The top shcots of the taller individuals are inmmne from harm. Thus a tree, once in the lead of its competitors, has a good chance to retain the lead over them.

IV. Grades of density of cover are: Pressed cover, Close cover, Light cover and Open cover. No strict definition of these terms can be given. Obviously the number of stems under pressed conditions is very large, and under open conditions very small.

Indications of a normal cover are:

a. Relation between length of crown and length of bole.

b. Normal diameter growth and height growth.

c. Proper participation of the various diameter classes in the volume of wood at hand. The normal participation in a pure, evenaged wood is for the

1st. Diameter class, $40 \%$ of total volume.

2nd. Diameter class, $24 \%$ of total volume.

3rd. Diameter class, $17 \%$ of total volume.

4th. Diameter class, $12 \%$ of total volume.

5 th. Diameter class, $7 \%$ of total volume.

If cover overhead is too dense, the first diameter class shows over $40 \%$ of volume and vice versa.

V. In nature, the same causes necessarily hav the same result. The causes of timber prodnction are soil and atmospheric food "falling" onto the soil in the shape of sunshine, moisture and air. Hence, whatever the species are, it seems as if the acre of ground, fully stocked, mnst produce on the annual average the same weight of timber, though not the same volnme of timber. Thus, ceteris paribus, species of light specific gravity are the best volume producers. Since, however, shade-bearing species arc better digestors of atmospheric and terrestrial food, the largest growth per acre per annum is obtained from shade bearers and "intermediates" of light weight (Hemlock, Spruce, Fir, Douglas Fir, White Pine, etc.).

In the virgin forest the annual production of wood fibre is exactly offset by the annual death and decay of wood fibre. The virgin forest is a forest seemingly in economic stagnation.

VI. The sectional area of a tree usually measured chest high $\left(4 \frac{1}{2}\right.$ feet above ground), inclusive of bark, is the area of the circle corresponding with the diameter measured chest high. 


\section{THE ART OF THE SECOND GROIVTH}

The sectional area of an acre of forest is the sum total of the sectional areas of the trees standing thereon. It rarely exceeds onehalf per cent. of the acreage of the ground, or 218 square feet per acre. On the Pacific Coast, more than twice this figure is reached by the Douglas Fir.

\section{E. Rotation.}

By rotation is understood the number of years which a seedling requires to reach maturity. For a second growth in America, rotations will vary in length from 60 years to 160 years, according to the species and local conditions. During a rotation a wood lot may pass through the cleaning stages, thinning stages, the stage of preparatory cutting, the seed-cutting stage and the stage of final removal. Out of thousands of specimens borne, but a few dozen persist to the end of the rotation.

\section{F. Size classes and age classes.}

I. Pinchot adopts the following seven age classes or size classes of trees in his "Primer:"

a. Seedlings, up to 3 feet high.

b. Small saplings, from 3 to 10 feet high.

c. Large saplings, 10 feet high to 4 inches diameter.

d. Small poles, from 4 inches to 8 inches diameter.

e. Large poles, from 8 inches to 12 inches diameter.

f. Standards, from 12 inches to 24 inches diameter.

g. Veterans, over 24 inches diameter.

II. During the sapling stage, the specimens form a thicket; during the pole stage, they form a polewood; and during the standard and veteran stage, a tree forest.

III. During the thinning stage (pole stages) of trees in an evenaged wood, the following classes of mess-mates might be distinguished:

a. After Schlich, "Dominant," "Dominated," "Suppressed, yet alive," and "Dead."

b. After Pinchot, "Dominant," "Retarded," and "Overtopped."

c. The usual classification, adopted by German foresters after Krafft is :

1. Predominating trees, having crown strikingly well developed.

2. Dominating trees, with well-developed erowns, forming the main cover overhead.

3. Condominating trees, with crowns of a fairly normal form, but of somewhat poor vigor, earrying, however, their crowns within the level of the main canopy. 
4. Dominated trees with erowns more or less arippled or pressed from the sides, subdivided into two sub-elasses, viz.:

a. Most of crown free from cover overhead.

b. Nost of erown underneath cover overhead.

5. Trees absolutely suppressed, standing entirely under the cover of others.

\section{G. Even-aged woods:}

Woods, the components of whieh difler in age by less than 25 years, are called "even-aged wooks." The strugrgle for existence between even-aged comrades can be alleviated readily by the forester's interforence.

In America, even-aged woods may be formed:

I. By Long Jeaf and by Cuban Pine.

11. By Jack Pine and Lodgepole Pine.

11I. By Bald Cypress.

1V. By Douglas Fir.

V. By Pinus echinata, taeda, strobus, ponderosa, virginiana on abandoned fields.

\section{H. Distribution of species.}

The vertieal distribution of the species depenis on the latitude and the proximity of the ocean, or better on sea winds. In the neighborliood of Biltmore, the following altitudes may be given:

spruce and Fir $-5,500$ feet.

Beech $-3,000$ to 6,000 feet.

Hemlock-3,000 to 3,800 feet.

Chestnut $-2,000$ to 5,000 feet.

( hestmut ()ak-2,000 to 4,000 feet.

Pignut Hickory-3,000 feet.

Bitternut Hiekory-3,800 feet.

Black Cherry-3,500 to 5,000 feet.

Pinus virginiana-2,000 to 2,500 feet.

Pinus strobus $-2,000$ to 3,500 feet.

Vellow Poplar-2,000 to 4,000 feet.

Buckeye-4,000 to 6,000 feet.

Red Oak-2,000 to 5,500 feet.

White Oak-2,000 to 5,000 feet.

Spanish Oak-2,000 to 3,800 feet.

Post Oak-2,000 to 3,000 feet.

l3ack Oak-2,000 to 3,600 feet.

Echinata-2,000 to 2,600 feet.

Rigrida-2,000 to 3,500 feet.

pungens-4.500 feet. 
Locust $-2,000$ to 5,500 feet.

Black Gum-2,000 to 4,000 feet.

Every species thrives best in certain centers, which are few in the case of the exacting and numerous in the case of modest species like Yellow Pine, both east and west.

Aside from vertical and horizontal elevation, the influence on distribution exercised by storm, snow and sleet is very marked.

\section{Paragraph VI. Light demanders and shade bearers.}

A. A plant is termed the more shade bearing or tolerant of shade, the less light it requires for the functions of assimilation, breathing, perspiration, flowering and fruiting. Only parasites live without light, and hence without chlorophyl.

B. The following characteristics, in their aggregate and not singly, may lead the observer to elassify a tree as a shade bearer:

I. Dense leaf canopy.

II. Leaves thin, dark, flat, numerous, not glossy, not downy, not bunched at the ends of the branches, with blades spread horizontally, withering quickly after separation from the branch.

III. Thin bark.

IV. Thick sapwood.

V. Branches persistent, spread flat or pointing downward, comparatively thin and interlacing. Crowns long.

VI. Little live soil cover, and a heavy layer of dead humus underneath leaf canopy.

VII. Dense stand of trees.

C. Factors influencing the relative demand for light within one and the same species are:

I. Latitude and hence intensity of insolation.

II. Site, which may be in the heart of a continent, or else at the edge of an ocean.

III. Exposure.

IV. Fertility of soil, and hence digestive power.

V. Age of plants.

VI. Distance between the crown levels of the shaded and of the shading trees.

Instances for I and III: 


\section{A IIERICAN SYLVICULTURE}

White Pine is, in the Soutl, almost shade bearing; in the North, it is almost light demanding.

Yellow Poplar stands heavy shading overhead on fertile soil.

D. The woody species, in their relative order of resistance against heary shading, might be arranged as follows:

I. Relative order for the Southern Appalachians:

Vitch Hazel.

Dogwood.

Fir.

Hemlock.

Hard Maple.

Chinquapin.

Black Gum.

spruce.

Linden.

Soft Maple.

White Pine.

Pinus virginiana.

Chestnut.

Red Oak.

White Oak.

Chestnut Oak.

Ash.

Spanish Oak.

Black Oak.

Finger Oak.

Post Oak.

Pinus rigida.

Black Loeust.

Poplar.

Hickory.

Pinus echinata.

Sassafras.

Unfortunately, at Biltmore, shade bearers are usually weeds interfering with the valuable species.

II. Pinchot gives the following schedule for the Adirondacks: Hard Maple.

Beech.

Hemlock.

spruce.

Balsam. 
Soft Maple.

Birch.

White Pine (intermediate).

Black Cherry.

Black and White Ash.

Bird Cherry.

Cottonwood.

Tamarack.

The trees above White Pine, Pinchot calls "tolerant" and those below White Pine, "intolerant of shade." Species neither tolerant nor intolerant are "intermediates."

III. The leading species of the United States, classed according to light or shade-demanding qualities are:

a. Eastern Conifers:

Long Leaf Pine-distinctly intolerant of shade.

| Echinata-light demander.

\& Taeda-intermediate.

7) Virginia-intermediate.

Rigida-not so tolerant as Virginiana.

Bald Cypress-light demander.

4 Chamaecyparis spheroidea-shade bearer.

5 spruce-fair shade bearer.

Balsam-intense shade bearer.

2 Hemlock-intense shade bearer.

14 Tamarack-light demander.

3 Arbor vitae-shade bearer.

White Pine-intermediate.

Jack Pine-light demanding towards intermediate.

1) Norway Pine-light demander.

b. Eastern hardwoods:

Beech-shade bearer.

Hard Maple-shade bearer.

Silver Maple-shade bearer.

Red Maple-sliade bearer.

Black Gum-shade bearer.

Sourwood-light demander.

Locust-light demander.

- Yellow Poplar-light demander.

Chestnut-intermediate.

14 Oaks-light demanders (White and Red Oak stand shade when young).

Elm-shade bearer. 


\section{A IIERICAN}

Birch-light demander or intermediate.

Black Walnut-intermediate.

Linden-shade bearer.

Cmbrella tree-less light demanding than Yellow Poplar.

cuemuber-less light demanding than Yellow Poplar.

ficamore-medium shade bearer.

Willows and Cottonwoods-light demanders.

Liquidambar-light demanter.

Ifickories-light demanders.

c. Western Conifers:

Donglas Fir-intermediate.

Ponderosa-light demander.

Nint l'ines-intense light demander.

Lodgepole Pine-intermediate.

Singar Pine-intense light demander.

Lawson Cypress-intense shade bearer.

Tide-land sprnce-shade bearer.

Redwood-shade bearer.

Western Hemlock-intense shade bearer.

Western Firs-intense shade hearers.

Larch-intense light demander.

Englemann's Spruce-slate bearer.

Colorado Blue Spruce-shade bearer.

\section{Paragraph VII. Pure versus mixed woods.}

\section{A. Conditions inviting pure woods and mixed woods.}

Conifers are more apt to grow in pure forests, owing to their greater modesty. Abroad, nj to a very recent time, the desire of the forester was to raise mixed woods, but quite recently the "Danish propaganda" has turned the minds of some foresters back to pure woods.

Severe climatic conditions and poor soil conditions invariably give one species the preponderance; for example: Bald Cypress rules in the swamps of the south, Tamarack in those of the North; Nut. Pines prevail in the semi-arid regions of the Southwest; Long Leaf Pine on poor sand in the South; Cuban Pine in half swamps of the Sonth; Red Spruee on the "Blaek Slopes" of New England; White Spruce in Northem Canada; Lodgepole Pines on old burns; Jack Pine on poor sand in the Lake States.

I'ure forests are sometimes in the interest of the owner, for 


\section{THE ART OF THE SECOND GROIVTH}

example: Pure Spruce near paper mills; Hickory near carriage works; Tan Bark Oak near tanneries.

A long rotation often leads to a pure forest, a short-lived admixture being gradually pressed out.

Abroad the forester is required to maintain the fertility and prodnctiveness of the soil. Since light-demanding species allow the soil to be baked by the sun during the pole and tree stage of the forest when grown purely, an admixture of shade bearers is advisable and is obtained by underplanting.

\section{B. Kinds of mixture.}

A mixture may be temporary or permanent; a mixture may be even aged or uneren aged; the species may or may not differ in height growth; the mixture may be composed of single individuals; or of strips, rows, bunches, groups; or it may show an irregular character.

In the course of time the original character of the mixture can be changed entirely by the forester or by nature.

\section{Advantages of mixtures.}

Mixed forests take advantage of existing differences of soil qualities; the moisture-demanding species gradually claiming the dells and the more modest kinds obtaining preponderance on the dry plateaus or spurs.

A mixture may form a preventive against late frost.

A mixture is better protected against damages by fire, insects, fungi, storms, snow, etc. At Biltmore, White Pine protects the Shortleaf Pine admirably, where the two are raised in alternating rows, during the thicket stage against damage by snow.

A mixture produces a better quality of humus (Pine and Oak humus is better than pure Oak humus or pure Pine humus.)

A mixture produces a larger quantity of timber for the above reasons in addition to the fact that a mixture allows its components to more fully utilize the productive factors of the air as well as those of the soil through

a. Difference of crown formation, crown levels, crown density;

b. Difference in root system (tap and flat-rooters mixed);

c. Difference in mineral and light requirements.

A mixture also tends to produce cleaner timber,-certainly so for the benefit of light demanders when placed in mixture with shade bearers.

For all these reasons a mixed forest may be said to produce a larger and safer revenue than a pure forest. 
Valuable species might be raised beyond the limits of their labitat in mixed forests.

\section{Objections to mixed forest.}

The administrative and the sylvicultural management of mixed woods is more difficult and hence more expensive than that of pure woods.

In America logging expenses are much increased where only one species can be utilized in mixed forests. Logging for Spruce on "Black Spruce Slopes" in the Adirondacks is relatively cheaper per thousand feet board measure than logging for spruce where spruce forms but one-third of the growing stock. This objection does not hold good, of course, where all species are marketable at the same time. Still, the logging, milling and marketing of numerous kinds is more difficult than that of a few.

E. Rules governing the composition of a mixture and rules for treating mixed forests (holding good for artificial and semi-artificial forests):

I. Species selected for a mixture must improve one another.

II. Each species should oceupy that section of ground on which it thrives best.

III. The mixture should at least maintain the productiveness of the soil.

IV. A light-demanding species mixed with a shade bearer must either be given an advance in age or else must naturally possess an advantage in rapidity of height growth; otherwise it soon disappears. This relative height growth is not a fixed quantity; it usually differs according to the soil and to the elimate.

$v$. The denser the forest cover is, the earlier and the more intense must be the help given to the species likely to be suppressed (Sassafras and Locust in mixture with Chestnut).

After Henry Mayr, species which are botanically different, form the most natural mixture (Oak and Pine at Biltmore; Birch and Spruce in Balsams; White Pine, Linden and Elm in Michigan). The number of exceptions to this rule is great (Norway and Jack Pine in Michigan; Red Firs and White Firs in the Pacific Coast States).

\section{Paragraph VIII. Dr. Henry Mayr's fundamental principles of Sylviculture.}

A. Forest is possible only where the mean temperature of the four months of most active growth averages 50 degrees Faht. or over. 
B. A mean summer temperature (May to August) of 53 to 59 degrees Faht. produces the Fir and Spruce zone of Europe, Asia and America. A mean summer temperature of 59 to 64 degrees is productive of Beech, also of White Oak, Maple, Hemlock and Chamaecyparis. A knowledge of the summer mean is essential when introducing exotics. A knowledge of the possibilities of forest growth in a given country implies a knowledge of the mean summer temperature.

Some very modest trees are unreliable as indicators or thermometers (e. g. Pinus echinata, Pinus ponderosa).

C. A species may be grown far from its original habitation, provided that the local climate of the new region is analogous to that of the old. If the exotic eomes from a warmer climate, it should be placed on south slopes with plenty of sun; if it comes from a colder climate it should be placed in moist soil and on cool aspects. There is no such thing as adaptation of trees to a different climate, or as acclimatization of trees. Walnut, Peach, and Black Locust have been grown in Germany for centuries, because the climate of naturalization was and is essentially identical with that of the natural habitat of the trees.

D. Tree specimens of a cold climate do not possess in themselves any special power of resistance to frost. It is useless to import seeds from colder climates in the hope of obtaining greater hardiness.

E. Species of trees growing in hot localities or else in open stands place comparatively small claims on the fertility of the soil. All species bear shade better when brought to a warmer climate and require more light when brought to a colder one.

F. In level countries, at not over 500 feet elevation, the habitation of a species depends on latitude considerably modified by sea winds. In many countries, away from the ocean, that modification is so strong as to create a dependence of the babitation more on longitudes than on latitudes. In high mountain regions, altitude may produce effects similar to those of latitude: it is, therefore, a mistake to label one species as a mountain species and another as a plains' species. In Eastern North America Picea rubens, in Western North America Douglas Fir, also Abies grandis and amabilis, bear witness to this truism.

G. The climatic needs of a species are better characterized by the forest zone than by the latitude or the altitude at which or up to which it grows. Even a knowledge of altitude and latitude 
combined furnishes insufficient information relative to such elimatic needs.

H. If there are found two neighboring species of the same genus in a gircn climatic zone, it is safe to assume that these two species were not mixed originally, but that each had its distinct habitation and that the mixture is due to the action of man.

I. In primitive forests, the species which harmonize are those which differ botanically.

J. When two kinds are so alike as to be almost varieties but isave, nevertleless, different climatic needs, then they are, in reality, true and distinct species (Douglas Fir in Colorado and Oregon).

K. Frost injury is always due to the death of the plasmodium killed by the direct action of the frost. The plasmodium is most sensitive during the time of cell formation and of active growth. The plasmodium in the inert stage, as in seeds, is actually insersitive.

L. All species become more hardy as they grow older. This is simply due to the trees rising above the cold layers of temperature near the gromnd and to the greater thickness and mass of the trunk, resisting rapid changes of temperature.

M. The degree of moisture in the air required for forest growth is $50 \%$ relative humidity during the growing season. The broad-leaved trees and the two and three needled Pines are the species best adapted to regions of extreme dryness or of sudden changes in atmospheric moisture.

N. The association of trees into a forest has the effect of increasing the relative humidity by not to exceed $10 \%$. Hence the necessity of maintaining forest in regions where the tension of watery vapor is close to $50 \%$. The partial destruction of a forest may entail the death of the remainder rendering reforestation impossible unless it is started from the nearest adjoining forest. Inside a forest the greater atmospheric humidity acts as beneficially as a moist ocean wind, lacking, however, the latter's violence.

O. It is in moist, cool localities (mountains and northern climate) that climate variations are the least extreme during the growing season. It is here that the annual rings are equal, the grain fine and regular, and the timber of the greatest commercial utility. 
P. The moister the climate, the easier becomes forest culture, and the forester is apt to make the least mistakes in thinnings, regeneration fellings, etc. Air moisture seems to exercise a favorable influence on the straightness of the stems.

Q. A failure of rain for several days may be fatal to young plants. The faculty of persistence increases with age, and the grown trees can endure long periods of drought. If, however, the lack of rain is such as to bring the sum total of precipitations during the four months of the growing season below the two-inch mark, then the forest disappears, even if the humidity of the air remains above $50 \%$. Exception: Immediate neighborhood of lakes and rivers with their sub-soil percolation.

R. A fairly moist soil is the best for all species in their optimum climate. In hotter places the locality must be more damp, while in colder ones it may be dry withont hiudering growth (White Pine in the Southern Appalachians in swamps, in Canada on dry soil; Sitka Spruce in Washington on wet land; In Alaska on dry land).

S. Snow protects those parts of a plant which it covers; it increases the danger, however, for the parts just above the snow level. Snowy winters are, therefore, useful to low plants, but harmful to trees.

T. As regards the winds, the most dangerous are those following the direction of the barometric minima, which travel in North America and in Europe from west to east; in East Asia from south to north. Next dangerous are the winds traveling in the opposite direction, whilst those from other points of the compass are more harmless. Every mountain, however, creates a deflection of the current and possibly a return in the opposite direction.

U. In their youth, the trees are almost indifferent to the quality of the soil; with increasing age their exigencies increase. Thus plantations on poor soil may thrive well for a number of years, to be suddenly arrested at the begimning of the pole stage.

V. In their most suitable situation (natural optimum) a species succeeds on soil of any mineral description. In a less favorable climate the soil requirements of the species increase.

w. The light most favorable to activity of the chlorophyl is not the light of the blazing sun, nor is it the diffused light coming through rain or fog, but that light which is reflected by 
brilliant white clouds. Leaf cover overhead is favorable when it filters the rays of a burning sun and unfarorable when it excessively reduces the intensity of insolation. Under a continental climate, clondles days are more numerous than near the coast. The influence of thinnings and removal cuttings on the remaining growth, consequently, depends on the continental position of a forest,-not solely on species and soil.

$\mathbf{x}$. The regeneration of forests approaching exploitable age is easiest in their optimum climate. If the climate is too warm, seed will be more abundant, and the young plants will endure cover better. The moisture of the air, however, is wanting, and the denser cover overhead may intercept too much of the needed rainfall.

If the climate is too cold, the moisture of the air indeed increases; but the production of seeds and the persistence under cover decrease.

Y. In mixed forests, artificial regeneration is more difficult than natural regeneration. A clean felling results in a capricious complication of natural laws and phenomena whose contrary actions are not easily understood. Natural regeneration, a mixture of species suitable to the locality, a crop resembling as elosely as possible the primitive state, such are the conditions which the forester should seek to realize for the avoidance of dangers as well as for the greatest possible yield of the most valuable produce. No method of treatment harmonizes better with nature's laws than the so-called selection system, when each tree is placed in a condition most favorable to its development, and when no single tree is removed for a purpose other than that of regeneration or improvement of the crop. 


\section{CHAPTER II}

\section{THE SEED FOREST}

\section{Paragraph IX. Genesis of the seed forest.}

A second growth can be started or born either naturally (from stump shoots, root suckers and self-sown seed) or artificially (by planting seeds, seedlings or cuttings). Forests born from stump sprouts, root suckers and cuttings are called "coppice forests" or "sprout forests." Forests born from seeds or seedlings are termed "high forests" or "seed forests."

\section{A. Planting in Europe.}

Prior to the year 1830, the European foresters did not know, practically speaking, of forest nurseries. The forests were regenerated by Natural Seed Regeneration (N. S. R., pronounce "enesar"), where seed forests were desired, or else were raised by planting the tree seeds directly on the site where the second growth was intended to stand.

Since the year 1830, seedlings, raised in forest nurseries, were planted on an increasing scale. Now-a-days, in central Europe, the forester bent on artificial regeneration of his stand of timber prefers planted seedlings to seeds directly planted, especially in the case of Yellow and White Pine, Spruce, Ash, Maple and Larch. Beech and Fir are invariably regenerated abroad from self-sown seed; also Oak in France, while in Germany acorns are planted usually.

\section{B. Advisability of planting in America.}

Excepting the case of the prairies and, possibly, the case of fields abandoned by farmers in the Eastern States, the idea of artificial propagation of forest crops (by planting) seems preposterous in America. As long as an acre of virgin forest can be bought for a lesser sum of money than is required, in the same locality, for the successful re-forestation of an acre of ground, the chances for a remunerative outcome of planting seem slim. However, the following points should not be lost sight of :

I. The stumpage prices apt to prevail in America in the rear 1960 are likely to equal those now prevailing abroad. Hence the 
same practice which is now remmerative abroad must prove paying in this country; possibly more paying for the reason that the value of the soil on which the growing (rop must yield an anmual dividend is abroad about ten times as high as it is in the United states.

II. An expense for taxes and administration is incurred annually lyy the forest owner, whether the ground is kept fully or only partly stocked; hence it seems a remunerative venture to-at leastreinforce natural regeneration by artificial planting.

1II. The growth of weeds naturally plentiful in primeval conditions cannot be orercome unless radical artificial remedies are adopted.

C. On the other hand, the following objections to planting must be considered:

I. As long as the American forest is much endangered by fire, it is unwise to invest any money in young growth for which the danger of de-truction by fire is excessive.

I1. Trees of a condition now considered "weeds" may gradually attain a -tumpage value (as (hestmut at Biltmore).

II1. Even European forestry is now reverting to a natural propagation of forests owing to the dangers usually inherent to artificial planting.

\section{Definitions.}

The word reforestation is used if the area to be planted has been previously occupied by tree growth.

The word afforestation is used if there was no tree growth on the plot for a number of years beforehand.

The term "direct seeding" is applied, by the Forest Service of the Inited States, to reforestation in all cases where the seeds are planted precisely on those sites in which the trees are meant to be raised.

Direct seeding is distinguished from indirect seeding or seeding in nurseries. In the latter case, the seeds are planted within forest nurseries, on seedbeds. The seedlings raised in the murseries are planted ("outplanted") on those sites which the trees are meant to re-stock.

\section{Paragraph X. The Seed.}

The quality of seeds is shown by their size, weiglit, color, scent. A tree standing in an open position, not too young and not too old, produces the best seeds. 


\section{THE ART OF THE SECOND GROWTH}

\section{A. Seed years:}

The atmospheric condition of the year or years during which the seed is formed influence the quality of the seed. Drought in summer and early frosts in fall cause the seeds to drop immature. Black Oaks and Pines require two years for the formation of seeds. Juniper three years. It seems as if all trees require a number of years for the preparation of seeds, inasmuch as the medullary rays before a seed year are found full of starch, and after a seed year devoid of starch. This phenomenon may explain the periodical occurrence of seed years in Bamboo and Canebrakes, in Chestnut, Oak, Beech, Pine, etc.

The length of the period elapsing between seed years depends on the local climate and the position of the trees, being short for trees standing in orchard-like positions on warm and sheltered ground where abundant heat allows of the rapid accumulation of starch.

\section{B. Rest:}

After dropping from the tree, all seeds undergo a period of rest in our climate. This rest is very short in the case of Cottonwood, Willow, Elm and Soft Maple. In the majority of eases, in Eastern North America, it lasts from November to April. In rare cases (German Ash, German Linden, Red Cedar, Hornbeam) the period of inactivity covers about seventeen months. Seeds which get too dry while stored, often show a prolonged period of rest. For White Oak acorns the period of rest is but one month; for Red Oak acorns five months. The assumption that frost is required during the resting period for the benefit of the seed is erroneous. The germinating percentage is greatest inmediately at the conclusion of the period of rest.

\section{Tests:}

Germinating tests are made with from 50 to 200 grains.

I. Water test applicable to large seeds. Thrown in water, the good seeds will sink, and the bad seeds will float.

II. Cutting tests, made with a knife, used for testing acorns, chestnuts, nuts of Nutpines, also seeds of Ash, Yellow Poplar, Beech, etc.

III. Hot-pan tests for conifers, which causes good seeds to jump and burst, poor seeds to burn and char.

IV. Pot tests made in the following manner: Fill the lower half of a flower pot with sawdust, the upper lalf with sand in which the seeds are imbedded. Place the pot in a basin partially filled with water, in a warm room. 
V. Flannel test: Place the seeds between two strips of flannel kept moist by running their ends into a bowl of water standing at a lower level.

VI. Test in the commercial-test apparatus, which consists of a bottom plate (glass or china), a bell-shaped top (same material) and a clay disk containinng 100 small grooves, which fits into the bottom plate. All three parts are open in the center. The clay disk is burned in such a way as to retain good hygroscopic qualities, and is boiled for a number of hours (in water) before using, to kill adherent spores of fungi. Moist sand is kept between the disk and the bottom plate. The grains of seed are inserted into the grooves.

\section{Paragiraph XI. Preparations for direct seeding.}

The germinating bed must offer the seed a proper, constant and equal supply of heat, oxygen and moisture. The actual amount of heat, oxygen and moisture required has not been ascertained scientifically. Observation in the woods is the best teacher of the conditions securing the largest possible germinating percentage for any given speeies.

The preparation for seed-planting may extend over the entire area to be planted; or over certain strips which may be interrupted or continuous; or it may merely involve the grubbing of plots, or the stirring of spots. Where the ravages of game are feared, it is advisable to work the soil irregularly, and not in a geometric order.

A. Removing the soil covers, such as briars, Kalmia, Chinquapin. mosses, dead leaves, humus. A plow and grubber (cultivator) or a harrow ean not be used usually for the purpose; the hoe (a strong make) is largely used abroad; weeds are removed with brush hooks or scythes or machetes or are, if possible, killed by deadening. In certain cases, an iron rake might do. Often it is necessary to remove the cover by fire; fire, however, produces a heavy growth of weeds on fertile soil (in Pisgal forest).

B. Loosening the soil. Just after logging, the soil has enough porosity to allow of the development of a second growth. On abandoned fields or in prairies, thorough working with the plow, often continued for a number of years, may or must precede the act of planting. 


\section{Paragraph XII. Securing and preparing the seeds.}

A. European tree seeds are usually bought from reliable dealers, who rival in furnishing the best seed at the lowest price, guaranteeing a certain percentage to germinate. In America, the forester must secure seeds himself, collecting them by contract, or preferably, by day work. Some European sylviculturists insist that seeds should be taken from the best and strongest trees exclusively. Mayr consider's special care superfluous.

The experiments conducted at Trippstadt, Germany, in connection with this problem, are of intense interest: Seeds of Pinus sylvestris were obtained from Finland, Belgium, Hungary, France, and Bavaria; were planted in the same nurseries; and were outplanted on the same planting site, by the same workmen and at the same time. After seven years from the time of planting, the plantations made with the various local strains or varieties of one and the same botanical species, Pinus sylvestris, exhibit very striking contrasts in their respective rates of growth, in their ranification, in their endurance of atmospheric calamities, in the ease of subduing the weeds surrounding the young plants, etc.

B. By " coning" is understood the extrication of coniferous seeds from the cones encasing them. "Coning" of Spruce, Pine, Fir and Larch on a commercial scale is practiced in Europe by Henry Keller, Appel \& Co. and A. Lecoq, all of Darmstadt, Germany.

Certain Pine species (Nutpines) have wingless seeds. The wings of other Pine seeds hold the grain in a claw.

The seed of Spruce lies in the wing as in a spoon; the seed of Larch and Fir is attached to the wing and is not easily separated.

Among the broad-leafed "cone bearers"-Alders, Birches and Magnolias-the "coning" of Magnolias alone offers some difficulties.

I. The methods of "coning" are as follows:

a. Coning by insolation, the oldest and safest method. Trays, the bottoms of which contain open lath work or wire netting, are placed in the sun and removed to a slied if rain threatens to fall. The cones are spread on the trays in layers not over two cones deep and are stirred with a rake. In place of trays, drums might be used to good advantage. In New Mexico, the cones are spread on beaten clay soil. At Biltmore, flat barn roofs have answered the purpose. In a cold climate the sun process allows the seeds to be obtained but at a time too late for seed planting. The germinating percentage of seeds obtained by the sun process is, otherwise, superior to that of seeds coned by other methods. 
b. Coning by stove heat.

It is essential that the heat in the coning room slould not reach 110 degrees. Thorough ventilation is required to prevent sweating and moulding of cones. The cones are spread in the coning-room in thin layers on shelves or screens, through the interstices of which the seeds drop. The cones are stirred three or four times a day.

It is mwise to have the stove in the coning-room. An American liot-air furnace in the basement is well adapted to furnish the heat.

Many of the large European forest administrations have such or similar arrangements for coning.

c. Commerical method.

In the commerical establishments, heat is supplied by steam pipes, controlled by automatic devices. The trays or drums are kept in a rocking motion by machinery. The seeds, after falling through the interstices of the trays, are at once conducted to a cool room.

II. Separating the seeds from their wings.

In the case of Pine and spruce seeds, flailing is sufficient. It is not advisable to wet the seeds before flailing. For Larch, rubber millstones are used, the distance between the stones being equal to the smallest diameter of the seed.

III. Cleaning the seed from dust, needles and wings. The seeds are freed from admixtures by fanning, shoveling, centrifuge or any grain-cleaning machine. The large commercial establishments drop the seeds on endless rolls of cloth, which are moving on an incline. The heavy seeds slide down, whilst dust and wings are carried uphill.

\section{Work of the U. S. Forest Service:}

a. Extracting seeds: The Forest Service obtains the seeds of Douglas Fir, of Spruce, and of Pine in the West by dreing the cones on canvas. The canvas is raised above the ground during wet spells and rolled up into a sack if need be. The cones of Lodge Pole Pine can be collected in summer. The Lodge Pole cones might be soaked before drying, to facilitate opening. Twelve square feet of canvas are required, on an average, per bushel of cones. Temperatures of 140 degrees rednce the vitality of the seeds.

b. Cleaning: For the cleaning of seeds are used:

(a) Fanning mills.

(b) Corn shellers.

(c) Two boards, in the case of Juniper berries, between which the berries are rubbed. 
c. Results of Forest Service seed collection:

\begin{tabular}{|c|c|c|c|c|c|}
\hline Species & $\begin{array}{c}\text { Germi- } \\
\text { nating } \\
\text { percent- } \\
\text { age }\end{array}$ & $\begin{array}{l}\text { No. of } \\
\text { lbs. } \\
\text { per } \\
\text { bushel }\end{array}$ & $\begin{array}{c}\text { Seeds } \\
\text { per lb. }\end{array}$ & $\begin{array}{c}\text { Cost } \\
\text { per lb. }\end{array}$ & $\begin{array}{c}\text { Commer- } \\
\text { cial } \\
\text { price } \\
\text { per lb. }\end{array}$ \\
\hline 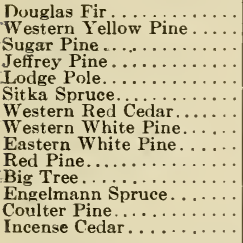 & $\begin{array}{l}55 \\
75 \\
51 \\
86 \\
83 \\
51 \\
67 \\
57 \\
55 \\
89 \\
18 \\
60 \\
\cdots\end{array}$ & $\begin{array}{l}1 \frac{1}{4} \\
1 \frac{1}{2} \\
1 \frac{1}{2} \\
\cdots \\
1 \frac{1}{5} \\
1 \frac{1}{4} \\
1^{\frac{3}{4}} \\
1.1 \\
1 \\
8 \\
\cdots \\
\cdots\end{array}$ & $\begin{array}{c}43,000 \\
9,000-13,500 \\
2,400 \\
3,100 \\
120,000 \\
400,000 \\
400,000 \\
28,000 \\
26,000 \\
55,000 \\
75,000 \\
175,000 \\
\ldots \ldots . \\
\ldots \ldots\end{array}$ & $\begin{array}{r}\$ 1.20 \\
0.80 \\
0.50 \\
4.00 \\
2.00 \\
1.25 \\
\cdots \\
\cdots \\
3.00 \\
1.50 \\
1.20\end{array}$ & $\begin{array}{c}\$ 2.50 \\
2.25 \\
\cdots \\
3.00-7.00 \\
4.00 \\
3.00-4.00 \\
\ldots \\
\cdots \\
4.25 \\
3.00 \\
\ldots\end{array}$ \\
\hline
\end{tabular}

All of the data tabulated refer to cleaned seeds, free from wings, dust and dirt.

V. Statistical notes.

a. Spruce in the Adirondacks (after Clifford R. Pettis).

1. Cost of picking cones 50 cents per bushel (green).

2. One bushel of green cones yields two bushels of dry cones, containing $17 / 8$ pounds equal to $1 \frac{1}{2}$ quarts of Spruce seeds.

3. One bushel of cones weighs 60 pounds, one bushel of seeds 40 pounds.

4. One pound of seed contains 150,000 grains.

5. It costs 95 cents to collect, cone and clean one pound of seeds.

b. White Pine at Biltmore.

1. 100 bushels of cones will weigh 2,200 pounds (a "long ton").

2. One bushel contains 600 to 700 cones, and yields, on an :average, $1 / 2$ pound of absolutely clean, wingless seeds.

3 . One pound of such seed contains 25,000 to 30,000 grains.

c. Yellow Pine (ponderosa) in New Mexico (after Wm. H. Mast).

1. One bushel of cones yields 1.55 pounds of clean seed.

2. The expense of collecting, coning and cleaning averages -23 cents per pound.

d. Colorado Blue Spruce in New Mexico (after Wm. H. Mast).

1. One bushel of cones yields 1.2 pounds of clean seeds.

2. The expense of coning, collecting and cleaning averages 23 cents per pound.

e. Shortleaf Pine (Pinus echinata) at Biltmore.

One bushel of cones yields one pound of clean, wingless seeds at an expense of $\$ 1.00$ per pound. 
C. Seeds stored beyond the duration of their natural period of rest show a reduced percentage of germination. The percentage might be increased by the use of slightly acid solutions, lime water or hot water. Coniferous seeds are often placed in cold water for three to seven days previous to planting; seeds thus treated, however, must be supplied after planting with moisture artificially if dronght sets in.

The United States Forest Service, under the guidance of Mr. Raphael Zon, has made extensive experiments concerning the best conditions for the storage of seeds. Seeds were stored at thirteen different locations, so as to get the influence of the locality on retention of vitality. At each locality one part of the seeds was kept in the office above freezing, another in an outside barm, and a third in a cellar. Storing in basements has proven best so far. Seeds stored in Colorado and New Mexico were best as to locality. In Washington City, seeds stored at 6 degrees $F$. gave the best results.

Tests are now being made showing the influence of the container on vitality; amongst these are tested "manila" containers, bags soaked in paraffin, oil-cloth bags, and sealed glass containers. The best results were obtained so far in sealed glass containers, and the poorest in oil-cloth bags.

D. The "malting" of seeds (placing the seeds in heaps, moistening them and stirring them in a warm room) is a rather dangerous procedure. After Weise, Donglas Fir and White Pine seeds should be mixed with moist and fertile soil and stable manure, to be then exposed to a hot-house temperature unti! the germs begin to show. S. B. Green recommends to pour boiling water on the seeds of Locust, Honey-Locust and Coffee-tree, and to allow the seeds to remain in the water until it is cold, planting immediately thereafter.

\section{Paragraph XIII. Direct seeding.}

Seeds should not be planted on rainy days, especially not on clay soil. For broadeast planting, the area to be planted and the seed are divided into equal lots. The quantity of seed allotted to the unit of space is divided into halves. Each half is sown separately by going over the ground crosswise.

Broadeast planting is rare nowadays.

Rough nursery beds, (either ruming full length of the area or interrupted beds), furrows or banks are frequently proviled. Nar- 
row trenches may be pressed into the beds or banks with the help of a board, a hoe handle or a wheel.

The seed is usually sown by hand, possibly with the help of a beer bottle, a so-called seed horn, or with a seed-planting machine. The machine should be used on ground as well prepared as a seedbed in a nursery.

"Covering" purports to place or rather press the seeds into contact with the mineral soil on all sides; to prevent sudden changes of air temperature from striking the seed; to prevent the seeds from drying out under excessive exposure to the air. The eover must be such as to allow a young germ to push its cotyledons through the eover easily. The seeds keeping their cotyledons below ground (Oaks, Sassafras, Chestnut) allow of a heavy cover.

In the case of eoniferous seeds, a proper eover is secured with the rake or with a brush drag; or by marehing the planters, a band of sheep or a herd of cattle orer the plantation. Heary seeds are often strewn on the ground without any preparation and then eovered with a shovelful of dirt. In America seed-planting in the open is unadvisable as long as the prices of seeds maintain their present level.

"Planting of eones" was the leading method used a hundred years ago by European foresters. The cones were strewn on the ground and stirred periodically, by sheep, with good results.

Seeds more than one-quarter inch thick, especially nuts, are usually dibbled with a dibbling hammer, wedge, knife, hoe, spade, etc. The hole made should place the seed at the best depth. The hole is closed by side pressure, by the foot or the hammer, or by allowing a lifted sod to drop back into place. The common plant. ing sparle puts the seeds too deep.

A. The quantity of seeds used per acre depends on:

Price of seed.

Density of stand desired.

Tenderness, sensitiveness and rate of growth of species.

Local damage from late frost, drought, weeds, insects, mice, squirrels, rabbits, game, birds, ete.

Quality of both soil and seeds.

Fineness of prepared soil.

Method of planting by hand or machine, regular or irregular, broadcast or in patchwork. Planting seeds in bands or strips requires two-thirds or three-fourths of broadcast amount; planting in patches one-half, in seedspots one-fomth of the quantity required for broadcasting. 


\section{B. Figures adopted at Biltmore for broadcast planting} are, per acre:

White Oak and Chestuut Oak, $12 \mathrm{bu}$.

lied Oak and Black (Oak, s bu.

Ash, 40 llss.

Beech, $130 \mathrm{lbs}$.

Maple, $40 \mathrm{lbs}$.

Elm, 24 lbs.

Birch, 32 lbs.

Firs, $4.5 \mathrm{lbs}$.

spruce, $10 \mathrm{lbs}$.

Larch, $10 \mathrm{lbs}$.

Yellow Pine, 8 lbs.

White Pine, 12 ibs.

C. Small seeds: Number of seeds in one pound (approximater, all coniferous seeds without wings):

\begin{tabular}{|c|c|}
\hline Ash $\ldots \ldots \ldots$ & 6,200 \\
\hline 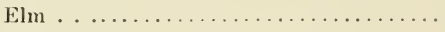 & 55,000 \\
\hline Silver Fir $\ldots \ldots \ldots \ldots \ldots \ldots \ldots \ldots \ldots \ldots \ldots \ldots \ldots \ldots \ldots$ & 9,000 \\
\hline Tamarack . . . . . . . . . . . & 70,000 \\
\hline White Pine $\ldots \ldots \ldots \ldots \ldots \ldots \ldots \ldots$ & 30,000 \\
\hline 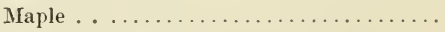 & 5,000 \\
\hline Birch . . . . . . . . . . . . . & 80,000 \\
\hline European Spruce $\ldots \ldots \ldots \ldots \ldots \ldots \ldots$ & 56,000 \\
\hline Seoteh Pine $\ldots \ldots \ldots \ldots \ldots \ldots \ldots \ldots \ldots \ldots \ldots \ldots \ldots$ & 70,000 \\
\hline 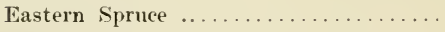 & 150,000 \\
\hline Western Yellow Pine ............... & 12,000 \\
\hline
\end{tabular}

D. Large seeds: Number of seeds in one bushel are:

White Oak ................. 8,000

Red Oak ................... 3,000

Walnuts . . . . . $8 \ldots \ldots \ldots \ldots \ldots \ldots \ldots . \ldots \ldots$

E. Work of the Forest Service: The Forest Service has tried direct seeding-first in 1905 , with phenomenal suecess, in the Black Hills of South Dakota. Since that time the success obtained has been more limited. In 1910, approximately 14,000 acres were planted by direct seeding in the National Forests. Seventy-five per cent. of all Service planting is seedspot work.

After Raphael Zon, U. S. Forest Service, the following quantities of seed should be used for direct seeding in the National Forests: 


\begin{tabular}{|c|c|c|}
\hline \multirow{2}{*}{ Species of Trees } & \multicolumn{2}{|c|}{ Pounds per Acre } \\
\hline & $\begin{array}{l}\text { Broadcast } \\
\text { method }\end{array}$ & $\begin{array}{c}\text { Seedspot } \\
\text { method }\end{array}$ \\
\hline 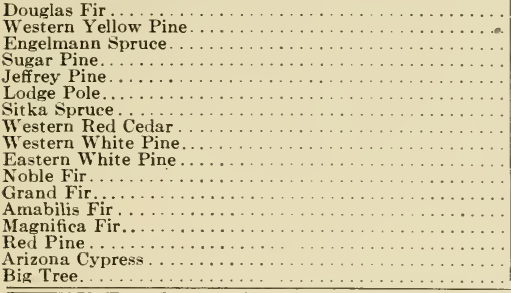 & $\begin{array}{l}3-5 \\
5-8 \\
1 \frac{1}{2}-3 \\
6-10 \\
8-12 \\
1 \frac{1}{2}-3 \\
1 \frac{1}{2}-3 \\
1 \frac{1}{2}-2 \frac{1}{2} \\
6-8 \\
5-7 \\
8-10 \\
8-10 \\
8-10 \\
8-10 \\
\cdots \cdots \\
\cdots \cdots\end{array}$ & $\begin{array}{l}1 \\
2 \frac{1}{2} \\
3 \\
3 \\
3 \frac{1}{5} \\
1 \\
1 \\
1 \\
1 \\
2 \frac{1}{2} \\
2 \frac{1}{2} \\
3 \\
3 \\
3 \\
3 \\
1 \frac{1}{2} \\
3 \\
2 \\
\end{array}$ \\
\hline
\end{tabular}

In the case of seedspots, Mr. R. Zon figures on spots 12-20 inches square, with the sod thrown on the South side, or else below the spot, the spots to be spaced 6 by 6 feet, and 12 seeds (only) to be used per spot.

The cost, per acre, incurred by the Forest Service for direct seeding in the National Forests depends on the character of the land, the method used, and on the species of trees to be raised. Mr. R. Zon gives the following figures for three different classes of land seeded directly:

\begin{tabular}{|c|c|c|c|c|}
\hline & & \multicolumn{3}{|c|}{ Cost per Acre } \\
\hline & & $\begin{array}{l}\text { Norway } \\
\text { Spruce }\end{array}$ & $\begin{array}{l}\text { Yellow } \\
\text { Pine }\end{array}$ & $\begin{array}{c}\text { Douglas } \\
\text { Fir }\end{array}$ \\
\hline \multirow{6}{*}{$\begin{array}{r}\text { 1st Class: } \\
\text { (a) } \\
\text { (b) }\end{array}$} & $\begin{array}{l}\text { Level and open country, light soil, no } \\
\text { debris. }\end{array}$ & $\$$ & $\$$ & $\$$ \\
\hline & Seed-spot method: Spots 12 in. sq.. & & & \\
\hline & $\begin{array}{l}6 \mathrm{ft} \text {. apart, } 12 \text { grains per spot:- } \\
\text { Double furrows } 8 \mathrm{ft} \text {, apart, } 8 \text { seeds }\end{array}$ & 2.10 & 3.70 & 2.49 \\
\hline & per foot of furrow, harrowed be- & & & \\
\hline & $\begin{array}{l}\text { tore and atter seeding:- } \\
\text { Broadcasting, without soil prepara- }\end{array}$ & 3.75 & 13.03 & 5.79 \\
\hline & tion, 100,000 seeds per acre:- & 1.52 & 12.62 & 4.22 \\
\hline \multirow[t]{5}{*}{ 2nd Class: } & New burns on moderately level & & & \\
\hline & $\begin{array}{l}\text { ground, large quantities of down } \\
\text { timber; soil, clay-loam. }\end{array}$ & & & \\
\hline & Seedspots 12 in. sq., $9 \mathrm{ft}$. apart, $10-15$ & & & \\
\hline & $\begin{array}{l}\text { seeds per spot:- } \\
\text { Broadcasting without soil prepara- }\end{array}$ & 1.86 & 2.55 & 2.00 \\
\hline & tion:- & 1.65 & 12.75 & 4.35 \\
\hline \multirow{2}{*}{$\begin{array}{r}\text { 3rd Class: } \\
\text { (a) }\end{array}$} & $\begin{array}{l}\text { Steep slopes, down timber, loose rock, } \\
\text { debris. }\end{array}$ & & & \\
\hline & $\begin{array}{l}\text { Seedspots, } 12 \text { in. sq., } 6 \mathrm{ft} \text {. by } 6 \mathrm{ft} . \\
\text { ground dug up } 4 \text { in. deep, } 10-15\end{array}$ & & & \\
\hline \multirow[t]{2}{*}{ (b) } & $\begin{array}{l}\text { seeds per spot:- } \\
\text { Broadcasting without soil prepara- }\end{array}$ & 2.20 & 3.89 & 2.59 \\
\hline & tion:- & 1.85 & 12.95 & 4.5 .5 \\
\hline
\end{tabular}




\section{Paragraph XIV. Season for direct seeding.}

For Cottonwoods, Elms (execpting Red or Slippery Elm), Soft Maple and Mulberry, the best time of planting is nature's time,immediately after the fall of the seeds-in early summer. In the case of the species enumerated, the period of rest is very short and the seedlings starting rapidly have time to lignify before winter. In all other cases the forester may plant either in fall or in spring. Planting in winter is usually prevented by the condition of the soil.

\section{A. Planting in fall invites:}

I. Inroads of animals in winter.

II. Washing of seed when snow melts.

III. Damage from late frost, since planted seeds sprout early in spring.

\section{B. Spring planting necessitates:}

I. Expense for seed storage over winter.

II. Checks during storage, injurions to germinating percentage.

III. Higher expense for planting, the work taking place at a time when labor is scarce.

Spring planting forms the rule, except with Fir, Beech, Chestnut, White Oak.

In semi-tropical regions or places of periodical drought, the best planting time is the fortnight preceding the rainy period. On dry soil sceds are planted as early in spring as possible so as to profit from the moisture left by melting snow.

Seeds which maturally germinate 18 months after maturity (Red Cedar, Hornbeam, some Ashes, some Basswoods) require stratification: Place seels, in dry soil, in a ditch ten inches deep and ten inches wide, to a depth of five inches. Cover seeds with straw and dry weeds, and finally with dirt. After the lapse of a year the seeds are ready for planting.

In the Rockies, and also on the Pacific Coast, fall seeding is preferable to spring seeding. It has been found, however, that for Wyoming and Eastern Montana the early spring, and that for Arizona and New Mexico the summer are the most desirable periods for direct seeding (R. Zon).

\section{Paraǵraph XV. Auxiliaries to direct seeding.}

A. Means to protect species needing shade in earliest youth.

I. Plant seeds with oats, barley or summer rye, planting the grain in quantities not to exceed $75 \%$ of the normal. Cut grain 


\section{THE ART OF THE SECOND GROWTH}

crops high. This method was used regularly 100 years ago, for European Pine and White Oak, possibly with a view to eariy returns, possibly to avert ravages of field mice and birds.

II. Certain species, tender and shade demanding in early youth like Beech and Fir, cannot well be raised in the open, unless an usher growth 12 to 15 years older (of Yellow Pine, Sassafras, Black Locust, Birch) is previously started on the ground. The usher growth is gradually removed when the seedlings underneath want "skylight." In semi-arid parts such usher growth is perhaps doubly advisable; further in prairies, where Poplars and Willows, Box Elder and Soft Maple might serve as ushers.

\section{B. Means to protect the seed plantation from animals} and weeds.

I. Against seed-eating animals. Planting in late spring offers some protection. Planting in sprouting condition protects heavy seeds from rodents; slight coating of red lead protects conifers from birls. A watchman might be kept on large plantations, to scare the birds away. By coating large seeds with tar, crows might be kept away.

On wild land the damage by rodents is much greater than it is on land in enltivation or on large burns. Tree seeds are more liked by birds than are farm grains. In the West, rodents must be poisoned prior to any direct seeding. The United States Biological Survey, on the basis of extensive investigations, recommends different poisons for the different rodents, as follows:

(a) Formula for poisoning chip-munks and ground squirrels:

Strychnia sulphide, one ounce, and saccharine, one teaspoon, are dissolved in water by boiling. Add one-half cup of laundry starch, one quart of water, and boil till the mass thickens. Then mix the poison with 20 pounds of barley, securing a thorongh coating of the grains of barley. The best season is spring and early summer.

(b) Formula for mice:

Heat 16 quarts of wheat slightly; sprinkle thereon one ounce of acid, alcaloid, or sulphide of strychnia and one teaspoonful of saccharine; that done, mix the poisoned wheat with one pint of melted tallow.

(c) Formula for rabbits:

Use the twigs of fruit trees in lieu of barley; otherwise proceed as for chip-munks.

One bushel of poisoned grain will serve 40 acres thoroughly. 
II. Against weeds. Light covers of weeds are no disadrantage. Where weeds are heavy, seedlings should be planted, rather than seeds. Mowing (with seythe) weeds and crushing briars-preferably before weeas are seeding-is recommended. Where seeds are planted in rows or furrows on abandoned fields, cultivation checks weeds.

III. Against domestic animals. Pasture is not permissible in seed plantations before the thicket stage is past.

C. Reinforcing. Bare spots where the seeds have failed are usually reinforced by planted seedlings. The latter are taken from adjoining dense spots. In broad-leaved species, the blanks where seeding has failed, had better be marked during the preceding summer.

\section{Paragraph XVI Direct seeding of the broad- leaved species.}

\section{A. Acorns.}

The germinating acorn leaves the cotyledons below ground. If the first shoot is killed another forms at once. A shelter (or usher) growth to husband a plantation during its first years is hardly needed. Still plantations of Yellow Pine made to protect the Oaks planted between the Pines are often found abroad. Its long tap root prevents the Oak from being lifted by frost.

The soil cover given varies between one and three inches, according to the looseness and porosity of the soil. In case of spring sowing, germination requires from five to six weeks.

White Oak and chestnut Oak acorns planted in fall are often found sprouting before Christmas. The blumula in such eases, however, does not appear above the ground. Red Oak and Black Oak seem to sprout only in spring.

Acorns may be sown broadcast, especially on abandoned fields, or may be planted with oats and barley or summer rye. The cover is given with a larrow in ease of broadeast planting.

More often acorns are planted in furrows from two to seven feet apart. It is better to plant acorns closely within furrows far apart, than sparingly in furrows near together. The cover is given either by a second furrow or by hoe or rake.

Cultivation between rows (during summer) is practiced abroad, in the Rhine valley, for three or four years. On abandoned fields, 
cultivation seems required for the purpose of checking mice, squirrels, rabbits and weeds.

Where acorns are planted for mixture merely with Beech, Pine and Chestnut, irregular patches are planted or else "oversoiling" is used. In the latter case, a handful of acorns is roughly covered by a shovelful of dirt.

The usual method adopted abroad for raising Oak is dibbling. Care should be taken to prevent dibbled acorns from being placed too deeply.

The answer to the question whether spring or fall planting is better, depends on the number of enemies preying on the acorns in winter. Since the Black Oaks are not much molested, it might be as well to plant them in fall. Black Oaks suffer little in germinating percentage during winter storage. White Oak acorus, however, are much eaten by mice, squirrels, turkeys, hogs, etc., and would be planted in spring if winter storage did not invite a large loss of germinating percentage. For wintering White Oak acorns, it is best to place them (imitating nature) in sliglit layers under a cover of leaf-mould on fairly dry soil.

After Charles Heyer: Large baskets are roughly made on dry soil, the bottom and walls lined with moss; within are placed alternate layers of moss or sand and acorns. The basket is roofed with straw.

After Von Alemann: Ditches 8 feet wide by 10 inches deep are made on dry soil. The acorns must not be too wet when put into the ditch. The cover consists of a layer of vegetable matter. A rough hut is made all over the ditch, out of slabs, bark, twigs, etc. The acorns are stirred up twice a week during winter.

Heyer's method also requires a steep-walled ditch around the place of storage to keep mice out. Possibly it might be wise to keep soaked acorns submerged in rumning water.

After Hillerich (Forstmeister at Mitteldick) frost-proof cellars are constructed, some 6 foot deeper than the surface of the soil, stone-walled and stone-floored. The roof, straw-covered or tilecovered, is made fairly airtight. The acorns are spread on the floor in layers up to 2 feet deep, and are stirred over from week to week.

\section{B. Chestnuts.}

Chestnuts require more fertile and hence better-prepared soil than acorns. The nut has still more enemies than the White Oak acorn. Its germinating power is much reduced by dry storage over winter. The devices for storing acorns might be used as well for 
chestnuts. Possibly storage in the husk is preferable. Small quantities are stored in bran. At Biltmore the planting of Chestnut on abandoned fields is very unsuccessful, owing to enemies and poorness of soil. Abandoned fields in Pisgah Forest often show fair growth of chestnut-on better soil, especially on moister soil. No experience is at hand relative to nut-plantations on good land newly cut over. Chestnuts dibbled in at Biltmore to form a lower story beneath Yellow Pine are always eaten by squirrels.

\section{Walnuts.}

Walnuts, both Black and White, can be held over winter like potatoes, without loss. Yet fall planting is better where squirrels do not endanger the nuts.

Walnut has done well planted in furrows on abandoned fields at Biltmore where soil was good, without cultivation; on poor soil the weeds are choking it to death. The dibbling of walnut into woods just cut over lias been badly handicapped in Biltmore and Pisgah Forest by squirrels. Otherwise dibbling is the best method in the woods. Possibly the attacks of squirrels might be prevented by late-spring dibbling of nuts in sprouting condition.

\section{Birch.}

Birch seeds are very small, two-winged. European price for Betula lenta, lutea and nigra, $\$ 2.50$ per pound; Betula papyrifera, 62 cents per pound; for European White Birch (Betula alba), 8 cents per pound. Germinating percentage is bad, especially if seeds are not kept in loose stórage. The soil requires little preparation for seed planting. A large layer of mould must be removed. Seed can be planted any time from fall to spring. The old foresters used to plant the seed on the snow-so as to have the seeds washed into the soil by the melting snow.

The southern Birches, being solitary, might be planted in irregular patches or trenches, or in places where the mineral soil is exposed by the fall of trees whirled out of the ground with stumps and roots. European Birch is very modest, thriving well on dry soil.

The seedlings are very hardy. They suffer, however, from weeds, grass or leaves blown over them and depriving them of air and sunlight. Betula lenta, at Biltmore, is apt to "damp off."

\section{E. Beech.}

Nuts appear every three to seven years in the woods. In Michigan, the fall of 1911 brought a full mast. The nuts ripening in October had better be planted at once after ripening, though much endangered in winter by mice. Storage over winter, possible 


\section{THE ART OF THE SECOND GROWTH}

as in White Oak acorns, requires still more care. If spring planting is resorted to, nuts germinate within five or six weeks. Beech seedlings must have a shelter growth, and cannot survive in the open (excepting moist mountain slopes). The preparation of the soil is made with hoe or spade roughly, to a depth of three inches. Abroad, Beech is often used for an undergrowth in pole woods of Pine, Oak, Tamarack, Ash, etc., with a view to improving the humus and, indirectly, the boles of the trees forming the upper story. "Beech is the mother of the soil," because it furnishes the best humus. Beech is exacting; it requires strong and moist soil. Pure forests of Beech are found in the Southern Appalachians at 4,000-4,500 feet, with Poplars as standards in an upper story; pure beechwoods are frequent near Lonisville, Ky., in the Adirondacks and in Michigan. The price of German Beechnuts is two pounds for five cents.

\section{F. Alders.}

The Western Alder, Alnus Oregona, and the European Alder are valuable, while the Eastern Alder is only a shrub lining the creeks. European Alder is invaluable as a swamp tree and for plantations on very binding soil (clay pits). The seed of the European species is worth 10 cents per pound. Seeds ripen in October and are best kept over winter in the cones. The small seedling is not sensitive to heat and cold, but suffers under the heavy grass usually found in swamps. Since swamps are inaccessible in early spring, planting of seedlings is preferable to direct seeding. The Western Alder is the common usher for Lawson's Cypress.

\section{G. Ash.}

Seeds are abundant, showing about $70 \%$ germination. The seedling, in the first year, derelops to a length of eight or ten inches, from seeds covered with three-eighths inches of dirt. Little preparation of soil is needed. During the first two years, on good soil, a heavy shelter overhead is easily borne. American IIThite Ash may be grown on soil subject to long inundations.

White Ash is exacting. Within one and the same acre planted in White Ash, where the eye can scarcely perceive any undulations of the soil, the plantation may do excellently in slight depressions, and miserably on slight elevations.

Prices of Ash seeds: European Ash, 4 cents per pound; White Ash, 25 cents per pound.

At Biltmore, White Asli seeds planted in rows six feet apart have done well when the soil cover was not too heary. 


\section{H. Maple.}

Hard Maple seeds ripen in September. Silver and Red Maple seeds in Jume. It is wise to plant the seeds just when ripe. Price of seeds: Acer rubrum, $\$ 3.00$ per pound; Silver Maple, $\$ 1.00$ per pound; Sugar Maple, 80 cents per pound; European species, 4 cents to 5 cents per pound. The green germ of Amerisan Maples is said to die if the seeds are not planted at once. Soft Maples develop the seedling in the year of the seed. For seeds to be planted in the woods, the soil is prepared with the rake, and the seeds covered with one-half inch of soil. Maple planted on abandoned fields on Northern slopes, well watered and well drained, is likely to be successful. The young seedlings are sensitive at the time, when the cotyledons first appear above the ground, anil a cover overhead is advisable, where late frost prevails. On rocky soil in Northern coves, Maple seed is often strewn on the rocks, the rain being expected to wash the seeds into the crevices. Sugar Maple is more exacting than Soft Maple. It does not grow so well in damp soil as Soft or Red Maple. Acer negundo (Ash Leaf Maple) does well in the northern prairies. Seeds ripen in fall.

\section{Elms.}

Seeds flat, roundish, winged, the wing surromnding the seeds. Seeds, ripening in June, must be planted at once, since they eannot be kept in dry storage (except Slippery Elm). Germinating percentage is always small. Elms require such good soil that they cannot be raised except on strong, northern, moist soil of agricultural value. Elm seed is never planted broadcast; in suitable localities, seed might be planted in patches on soil roughly prepared with rake. Very little cover must be given.

Seeds cost: Ulmus americana 22 cents per pound. Ulmus campestris 6 cents per pound.

\section{J. Buckeye.}

The Asiatic species is valuable in game parks, its fruit being eaten by deer and boar. The American species are poisonous (flava and glabra). Seeds ripen in Octoler, are stored without loss, but can as well be planted in fall. After Weise, the seeds should be planted with the navel down. First class soil (Ohio) is required, or at Biltmore strong North coves at higher altitudes, where Buckeye is sometimes found in small groves. Planted in furrows on ahandoned fields (Biltmore), Buckeye has shown rapid progress during the first year, but has since made but small shoots. Seeds of the Asiatic species cost $21 / 4$ cents per pound. 


\section{THE ART OF THE SECOND GROITH}

\section{K. Black Locust.}

The seeds ripen in fall and are easily kept over winter uninjured by mice, birds or insects. To prevent seeds from lying over, S. B. Green advises to pour boiling water over them just before planting, a treatment causing many seeds to sprout at once. The fleshy, oval cotyledons and the primordial leaves are not pinnate. The tree is an exception to the rule of optimum depth of covering (the depth of long diameter of seed) since it does best when covered 2 to 3 inches deep. The seedlings are sensitive to late frosts. The planting had better be delayed until the danger of frost is past. The price of seeds, 5-10 cents per pound, renders Locust seeds the cheapest seed obtainable since the germinating pereentage is high. The seedlings grow until late fall, when they reach nearly two feet in height. At Biltmore, Black Locust is planted into Oak coppice on raked patches, with the rake, and on abandoned fields in furrows 5 to 6 feet apart. Five pounds per acre is enough. Plantations suffer from ground mice and, later on, from insects (Cyllene, Ecdytolopha). Locust thrives on agricultural soil; it is used in Europe to réforest the Hungarian prairies; further along railroad cuts. Forest-grown Locust is superior to field-grown Loeust.

\section{Hickories.}

The nuts of the thin-shelled species (ovata and minima) cannot be held over winter and require fall planting. Seed plantations suffer from mice and squirrels, and especially from voles, which bite-off the seedlings below ground, row after row. Bitternut seems exempt from such attacks. The seedling, in the first years, spends all its energy in developing a large tap root. The plantations at Biltmore made in furrows on abandoned fields might have succeeded better had they been cultivated continuously to check the mice and voles. Hickory needs fertile, fresh soil; the "Hickory flats" in the virgin forest are convertible into superior farm land. Hickoria ovata, 13 cents per pound; Bitternut, Pignut or Mockernut, 15 cents per pound.

\section{Linden or Basswood.}

Seeds falling in early fall are always poor. The ripe seed (in bunches, attached to wingbracts) falls in late fall or winter. Linden is very exacting and pure woods are very rare. Planted in the forest, it serves but as an admixture. Seeds are planted in spring on soil roughly prepared with rake or hoe. The cotyledon is typically five-pronged, hand shaped. The young plant is so sensitive that cover overhead is strongly advisable. 


\section{N. Cucumber tree.}

Seeds ripening in cones late in fall are removed, with great trouble, by hand. Many seeds lic over. The seedling develops on good soil a very long and strong shaft. For forest planting, Cueumber is used but in patches, mixed with Chestnut and Yellow Poplar.

\section{O. Yellow Poplax or Tulip Tree.}

Seeds appear annually; of very low germinating percentage. Nature plants the seed between October and May, slowly dismembering the cone. Seeds may be planted in spring after loose storage. The cones are apt to heat and mould, if tightly packed. The cotyledons (size of a nickel) do not show the typieal lack of the tip of the leaf blade. They drop off (in strong seedlings) before July 15th. Seedlings do not suffer from mice. Heary rains, however, are apt to wash them out of the gromud. The young seedling stands a good deal of shade. If deprived of light entirely, it is certain to be killed by the first frost. Seeds cost 15 eents per pound. Large quantities are required for planting, say 50 pounds per acre. The seedling grows fast, at the age of two rears it is three feet high, on good soil. Where seeds are planted in the woods, it is necessary to eheck the weeds, especially on north slopes.

\section{P. Sassafras.}

It might be planted on poor abandoned fields as usher growth. At Biltmore, seeds gathered in late summer have failed to sprout, whether planted in fall or spring. The fleshy cotyledon is kept below ground at a depth of one and one-half inches. Possibly, the seed must pass through a bird before it ean sprout, or the flesh must be removed by hand or by malting.

\section{Q. Black Cherry.}

Primeval trees are found on fairly rich soil. The Cherry, however, can be easily raised on abandoned fields not better than those at Biltmore. During early youth, until pole stage, mice and rabbits peel the bark badly. The end of the annual shoot is almost always killed in winter. The small purple fruits ripening in early autumn are eagerly eaten by birds. The seeds, after passing throngh the bird, are scattered all over the woods. The seeds are easily kept over winter, but lie over if kept in a dry condition. A hot-water bath before planting might eause the seeds to germinate speedily. In woods, Cherry should be planted urider one-half inch dirt eover, irregularly, with full enjoyment of light. Seed 50 cents per pound. The seeds might be planted in rows on abandoned fields in mixture with Pines more cheaply than the seedlings. 


\section{R. Black Gum.}

Nyssa sylvatica nas never been raised on a large scale, owing to the low value of its timber. As an undergrowth or admixture with Hickory, Ash, Oak, etc., it might prove, however, a valuable tree, owing to its dense leaf canopy and owing to its shade-bearing qualities. The seeds, cherry-like, dark blue in fall, of acid taste, seem to appear anvually, and old trees are often surrounded by an abundance of seedlings; the latter, very light colored, are four inches high by July, showing two heavy oval entire cotyledons, whilst the primordial leaves show the proper fo:m. Seedlings do not seem to suffer from frost, heat or animals. On abandoned fields, however, Black Gum scems to come up from sprouts and not from seeds. The seed is not on the market.

\section{Paragraph XVII. Direct seeding of the conif- erous species.}

\section{A. Firs.}

Very intensive shade-bearers, the Firs eannot be raised without shelter overhead. The young seedling suffers much from frost and heat. Its six to ten cotyledons show two white stripes on the upper side. The young plant is apt to die from leaves smothering it. Its height growth, to the seventh year, is small whilst the seedling tries to establish a root system and to cover its growing space by long side branches. Fir is usually planted in irregular patches as an admixture, moss and mould being raked away. The seeds losing vitality quickly when winter-stored (unless stored in the disintegrating cones) are usually planted in the fall, in spite of impending ravages of mice and birds. The covering is from onefifth to one-third of an inch. Since the cones begin to dissolve in November, they must be gathered in early winter. Abies concolor, $\$ 3.00$ per pound; Abies fraseri, $\$ 3.50$ per pound; Abies amabilis, $\$ 4.50$ per pound; Abies balsamea, $\$ 1.00$ per pound; Abies grandis, $\$ 3.00$ per pound; Abies magnifica, $\$ 5.00$ per pound; Abies nobilis, $\$ 2.00$ per pound; Abies pectinata, 5 cents per pound.

\section{B. Spruce.}

Seeds ripen in the year of the flower and are enitted from the cones, which have become pendulous, between November and April. The seeds are easily wintered either within or without the cones; after some authors, preferably in the cones. Seed years occur at intervals of about five years. The germinating percentage is high. 
The seeds are usually planted late in spring after bird migration, either broadeast on ground roughly raked, or more of ten on interrupted beds from one to two feet wide, prepared with hoe and slightly raised over the general ground level. It is said that a man can plant one acre of ground in eight hours, using the rake. Previous to planting it is wise to moisten the seeds for three to five days in cold water, especially if the seeds are planted in late spring. The cover should be one-fifth inch. Germination takes place after four weeks with from six to eight cotyledons, serrate on the upper side. Young plants are sensitive to drought and readily raised by the frost. Spruce suffers from suppression by weeds and leaves. Its height growth is more rapid than that of Fir. Prices of seeds: Picea canadensis, $\$ 1.10$; excelsa, 13 cents; engelmanni, $\$ 5.50$; rubens, $\$ 4.25$; pungens, $\$ 5.00$; sitkaensis, $\$ 5.50$ per pound.

\section{Yellow Pines.}

On dry sandy soil, it is wise to plant in early spring, so as to find a moist seed bed. The young seedlings do not suffer from late frosts and are not apt to be lifted by winter frosts. The removal of stumps stops the attacks of stump-breeding bark beetles and snout beetles (weavils). Intensive loosening of the soil invites the attacks of junebugs, wire worms, etc., and is not needed on sandy soil. Broadcast seeding is advisable on soil slightly covered with grass; the cover should just be scratched with the harrow. The seed, unless planted with the rake, is embedded in the soil by driving sheep, cattle and hogs over it. Before planting it might be wise to fire the ground, notably so in the case of Jack Pine, Lodgepole Pine and Norway Pine. Yellow Pine is never planted in seedspots, since it comes up in larger groups, of even age. Planted under shelter it would not obtain enough sunlight. The seeds are often planted on long strips two or three feet wide, separated by trenches, the weeds and dirt removed from the trenches being heaped on the strips. On the very driest soil, Jack and Red Pine will do in the north; in the south, Long Leaf Pine. The moisture demands of Pinus taeda exceed those of Pinus mitis. Wet ground is required by Cuban Pine. Pinus ponderosa may grow on any soil and aspect, north and south. European Pine should not be tried in places where snowfall is heavy. The sand dunes at San Francisco are planted in Monterey Pine. A method much used abroad some 80 years ago was the planting of Pine cones (eight bushels of cones per acre). The cones were turned from time to time by a brush drag. Another old method for raising Pine consisted in planting the seeds on top of oats, barley or summer rye. 
The cover given should be one-fifth of an inch. The seeds are mulched for three to seven days, before planting, in cold water. old seeds are apt to lie over for a whole year. Germination occurs in from three to four weeks. The first leaves stand singly, and not in sheathed bunches. The primordial leaves are strongly serrate. The germinating percentage is high, say seventy to ninety per cent. The seedlings of Pinus rigida creep on the ground the first two years as if dwarfed. Prices: Banksiana, $\$ 5.00$; murrayana, $\$ 100.00$; inops or virginiana, $\$ 1.10$; jeffreyi, $\$ 4.00$; mitris, $\$ 10.00$; ponderosa, $\$ 2.50$; pungens, $\$ 4.50$; resinosa, $\$ 9.00$; rigida, $\$ 2.50$; European Scotcl Pine, 50 cents; tuberculata, $\$ 4.50$; taeda, $\$ 10,00$; palustris, $\$ 4.50$ per pound. In Jack Pine, Lodgepole Pine and Table Mountain Pine the seed is not emitted for a number of years from mature cones. At Biltmore, mitis drops the seed between November 1 and December 15; Palustris seeds seem to drop before December 15, since seedlings appear by middle of January.

In the arid West, and notably in the National Forests of Arizona, the Forest Service has met with unexpected difficulties in the afforestation of its lands with Western Yellow Pine. There are dry winds in spring; and September already brings heavy frosts which are more disastrous than is drought. The seedlings, nurseryraised, and kept in cold storage till the rainy season begins, are killed by the early frosts. Transplants, with deep-going roots, three years old, supposed to be drought-resisting, have died.

The Service has now adopted the following recipe: The nurseries are neither shaded nor are they subirrigated. Sprinkling must be light; if there were no sprinkling, the roots would go too deep; if there were heavy sprinkling, too much foliage would develop. Continuous cultivation is absolutely essential. The nursery is ploughed to a depth of eight inches; the manure is kept at a depth of three inches.

\section{White Pine.}

White Pine seeds cannot be kept so easily over winter as Yellow Pine seeds. The seed matures at Biltmore about September 15th, and falls at once after maturing. The European recipe, "to gather the seeds when drops of rosin appear on the cones," is misleading. After gathering, the cones should be fully matured by exposure to sunlight. Cones placed in heavy layers-over six inches-after gathering are apt to mould, when the seeds will be destroyed. White Pine cones placed in light layers on wire netting emit the seeds easily, when heat is applied, and when the cones are stirred several times a day. The rooms in which the coning takes place 
must be well ventilated. Seed years oceur in the South every three years-in the North, say, every seven years. Mulehing before planting, in case of direct seeding in spring, is absolutely necessary. Germination after three to four weeks; seven to ten eotyledons, primordial leaves singly. Seedlings suffer still more from fungi (honey fungus) than Yellow Pines. Owing to the high priee of seeds of White Pine, the seed is usually planted in murseries, and not in the woods. At Biltmore, planting of seed in patches with the rake without preceding preparation of soil, under light cover, has proven a failure. White Pine does well on abandoned fields after fires,--except on East and Sontheast slopes where flat-rooted plants are apt to be lifted by frost. Germinating pereentage up to $90 \%$. Seeds cost abont $\$ 1.50$ per pound.

\section{E. Hemlock.}

Seeds mature toward the end of September, are very small and easily remored. Seedlings are very shade bearing and minute. Hemlock cannot be grown in the open. Price of seed being high and natural regeneration being easy, seed plantations will not be made on a large seale. Price of seeds: canadensis, $\$ 3.50$; heterophylla, $\$ 8.00$; mertensiana, $\$ 5.50$ per pound.

\section{F. Larch.}

The cones are very tough and not easily opened by heat. It is hard to separate the wing from the seed. The germinating percentage is low. The seed is planted in spring on open ground, usually in patches, mixed with Pines, Spruces or Hardwoods. The planting of seed of northern Tamarack in northern swamps is out of the question. The height growth in early youth is rapid. Lareh puts heary demand on light. Cotyledons, five to seven in number, appear four weeks after planting. The seeds are mulched in cold water for at least a week before planting. The primordial leaves stand singly; brachyblasts are formed from the third summer on. Young shoots never show brachyblasts. Price of seeds: European Larch, 50 cents per pound; Japanese Larch (leptolepis) $\$ 2.50$ per pound.

\section{G. Douglas Fir.}

It had better be ealled Pseudoabies than Psendotsuga. Cones are ripe in Oetober; bracts are twice as long as seales; seeds fall immediately after maturing in fall. Germinating percentage is 20 to 30 per eent.; seed received from dealers is apt to lie over. Thorough mulehing or hot-house treatment (after Weise) increases the percentage and the rapidity of sprouting. Germination takes place 
after five to seren weeks. The five to seven cotyledons are pointed and show two white stripes and a raised midrib above.

Two distinct varieties of Douglas Fir:

a. Pacific Coast Douglas Fir, growing rapidly, foliage bluish, large cones, often two top shoots during summer, the second one usually from a side bud.

b. Rocky Mountain Douglas Fir, known as varietas glanca, owing to its grayish foliage, of very slow growth, greater hardiness, smaller cones, developing but one shoot amnually. Price of seeds: $\$ 3.75$ per pound.

\section{H. Lawson's Cypress.}

Cones blue brown, globular, only six scales, small, three seeds under scale, seeds two winged. Wing one-twenty-fifth inch wide. Seeds mature in September and October, falling at once. 150,000 grains per pound. Sprouting with two cotyledons only, one-fifth to one-third inch long. Foung seedlings stand the densest shade, notably of Alder. In the sapling stage, fungi seem to play havoc in the plantations, a fact which may explain the small range of the species. Seed 60 cents per pound.

I. Western Red Cedar (Thuja plicata).

Scales of cones oval and upright, covering pairs of seeds. Seeds two-winged; wings one-quarted inch long, elliptical, drawn in at top. One pound contains 300,000 grains. Two cotyledons only. Seedlings stand heavy shade. Seed costs $\$ 2.25$ per pound.

\section{Paragraph XVIII. Actual planting of seedlings: Introductory remarks.}

A. The forester uses seedlings one to ten years old or, better still, one to five years old. The planting expenses increase at a cubic ratio with the increasing weight of the plants.

B. Seedlings are planted either with or without "balls" of dirt. They are taken from the nursery or from the woods. Yellow Pines over three years must be planted as "ball plants." Ball planting is always safer, as it prevents a ioss of root fibres. Under any circumstances, it is wise to leave some dirt attached to the roots, preventing the roots from drying and allowing them to quickly re-establish their sucking contact with the pores of the soil.

C. The small stemlet of young seedlings might be cut off before planting (stump plants). Advantages of planting stumps: 
I. In case of Locust, etc., lack of thorns.

II. In ease of tap rooters (Walnut, Hickory, Oaks where loss of root fibre is great), rapid re-establishment of the equilibrium previously existing between water-sucking power and evaporation.

III. Certainty of planting the seedlings neither deeper nor higher than they were in the nursery.

Conifers eannot be stump planted.

If stump plants of Ash or Maple are to be used, stumps one and one-half to two inehes high sliould be left. In the case of Oak, the stemlet should be eut off just above the point of differentiation. Stumping seems praetieable in the case of Chestnut as well, and is often applied to Catalpa, Loeust and Honey-Locust. Stumping is objectionable on aecount of the rabbits eating the new shoots, or where weeds are rank.

D. Bunch planting is often practiced where very small seedlings, eleaply raised and not transplanted in the nursery, are thereafter exposed in the woods to atmosplierie hardships or to damage by animals. From two to thirty seedlings form a bunch planted into one hole. Bunch planting, although losing favor with the foresters abroad, is applied to German Spruce and Beech.

E. Plants may be planted irregularly or else in triangles, squares, rectangles. The advantage of an exact geometrical arrangement, which may be obtained with the help of long planting strings, bearing blue and red marks, are:

I. Saving of time and expense. Each workman is kept busy by the work of his neighbor, and none ean fall behind. Supervision by rangers is faeilitated.

II. The number of plants needed is easily found and the probable expense is more aecurately estimated.

III. Small seedlings ean be foumd easily thereafter in high weeds or grass.

IV. A regular plantation may be opened to pasture at an earlier date.

V. A mixture of species, and, later, underplanting are more readily obtained.

VI. The eleaning, thinning and pruning of the plantation is facilitated.

VII. Possibility of cultivation between the rows in prairies and on abandoned fields.

The triangular form gives at a given planting distance the largest number of plants per aere, distributes the growing space equally, and is therefore said to raise cleaner stems. The arrange- 
ment in squares allows for a given planting distance $15 \%$ less plants per acre than the triangular system.

The rectangular system, though scientifically objectionable, practically prevails over the others. The plantlets standing close within a row assist one another from early times on. Planting between the rows and the cultivation of slopes are facilitated within rectangles. It is said, however, that the saplings form large side branches and retain the same for a longer period of years. Rectangular plantations are known to suffer less from snowbreak.

F. Usually it is best to make the holes for the plants before planting,-unless, on clay soil, the holes are apt to collect water. The making of holes takes more time, in many a case, than the planting itself. It should not be done during the few spring days favorable to tree planting.

G. The rangers should make all needful preparations for planting several days or weeks before planting, securing the seedlings, "heeling them in" close to the plantation and getting the implements and tools in proper condition.

\begin{tabular}{|c|c|c|}
\hline $\begin{array}{l}\text { Planting } \\
\text { distance. } \\
\text { I foot }\end{array}$ & $\begin{array}{l}\text { No. of plants } \\
\text { per acre in } \\
\text { squares. } \\
43,560\end{array}$ & $\begin{array}{l}\text { No. of plants } \\
\text { per acre in } \\
\text { triangles. } \\
50,650\end{array}$ \\
\hline I foot & 43,560 & $\begin{array}{l}50,650 \\
12,674\end{array}$ \\
\hline$\ldots \ldots \ldots \ldots \ldots \ldots \ldots \ldots \ldots \ldots \ldots$, & 10,900 & 12,674 \\
\hline 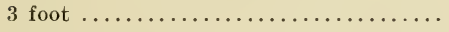 & 4.850 & 5,640 \\
\hline 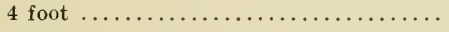 & 2,725 & 3,168 \\
\hline 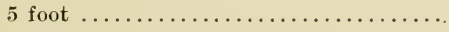 & 1,750 & 2,034 \\
\hline 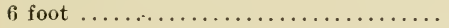 & 1,210 & 1,407 \\
\hline
\end{tabular}

\section{Paragraph XIX. Criteria of good seedlings.}

\section{A. The root system:}

The root system should be as compact as possible and as rich in fine hair fibres as possible, qualities which are obtained in a well-fertilized nursery. It must be rememberci that the small hair fibres are the feeders of seedlings, and that the stronger roots act merely as the skeleton giving the plant a firm anchorage in the soil.

A short exposure to sunlight and to dry winds kills the root hairs. Roots cannot live in air any better than fish, though requiring oxygen like fish (compare paragraph XXII). Toumey claims that "many successful planters never set evergreens until the root 
tips show signs of growth." This experience is entirely at variance with the universal European experience. Conifers are very sensitive against loss of root fibres. Fresh tips, evidently, are most apt to be injured in handling or by drought.

The pruning of the root system is a necessary evil in the case of very long tap roots. Conifers do not allow of it. Badly damaged roots may be clipped with a sharp knife just above the damaged point.

B. The shaftlet: Crooks are not injurious, the plant healing them quickly. Slender plants are not desirable, partly becanse they sway badly in the wind, thus getting loose in the soil; partly because slender shafts are due to an excessively close position in the nurseries. In the ease of broad-leaved seedlings one or two years old the shaft of spindling specimens may be cut-off without lasting injury (not in conifers).

C. The buds: The buds must have a healthy color, a large size and a goodly number. Small buds prove the plant to be weak; so that it lias a poor chance to withstand the hardships of transplanting. In conifers, the condition of the buds is especially telling. Poor and few buds in hardwoods render it advisable to lop the stemlets.

\section{Paragraph XX. Age, size and number of seed- lings used.}

A. Young plants are more easily transplanted than old plants, the loss of roots being smaller. Large saplings (10 feet high to 4 inches in diameter) are transplanted at great expense and great risk. They must be transplanted with big balls of dirt attached.

B. The number of plants used in Europe varies between 1,000 and 40,000 specimens per acre in case of Pines, Spruces and Beeches. The advantage of a large number of small plants is:

I. Better chance for nature to select the fittest.

II. Less reinforcing required.

III. Even unexperienced planters can be used.

IV. Plant material is very cheap.

$V$. Larger returns from first thinning and clearer boles.

On the other hand, the advantage of planting stronger seedlings, especially transplants three to six years old, lies in the following points :

VI. On poor soil, strong plants have a better chance.

VII. Older plants have already overcome the "measles" of childhood (-fungi, insect diseases-) to a large extent. 
VIII. Such plantations suffer less from snowbreak.

IX. The rotation is shortened by a number of years. In a White Pine plantation made with seedlings seren years old, instead of seedlings two years old, the rotation is reduced from fifty to forty-five years; and the original cost of planting may be $2 \pi \%$ higher, figuring at $5 \%$ interest; $22 \%$ higher, figuring at $4 \%$ interest: $13 \%$ higher, figuring at $3 \%$ interest.

C. Generally speaking, Oak, Hickory and Walnut should be planted one year old on account of the large size of the tap roots. Spruce, Fir and Hemlock should be planted three to five years old, after previous transplanting in the nursery. Ash should be planted six years old when used in moist sites having a luxurious growth of weeds. Yellow Pine must always be planted one or two years old, unless ball planting is resorted to.

After Toumey: For the prairies, yearlings are best in case of Cottonwoods, Box Elder, Soft Maple (Soft Maple sprouts in Junc and is very small in fall), Russian Mulberry, Catalpa, Walnut, Black Cherry, Locust and Honey-Locust. At Biltmore, Black Cherry transplants three years old do very well. Locusts two years old are clipped back. Maple and Ash are transplanted and used three to four years old; Yellow Pines used one or two years old; White Pines two, three or four years old; Catalpa one year old, etc.

\section{Paragiraph XXI. Lifting seedlings from nursery beds.}

It is not advisable to plow the seedlings out of the ground or to tear them out with tongs. In the case of species having small reproductive power (Conifers, Beech, Birch) additional care is needed. The spade should be used; and the plant should be lifted together with large clumps of dirt which, thrown on the ground, collapse and allow of the safe extrication of the plants contained in the clumps.

It is wise, carriage charges permitting, to allow some dirt to stick to the roots. On more binding soil the hollow cylinder spade might be used for lifting small plants. Plants should be well covered with burlaps, wet moss, dirt, etc., at once after digging. Plants left unearthed for a number of days should be heeled-in thoroughly, shinglelike, one row covering the other, in a shady place.

A machine lifting the seedling from (sandy) nursery beds securely, row by row, is used in the state nurseries of Hessen. It is constructed by Forstwart Jaudenburger. 


\section{Paragraph XXII. Transportation of seedlings.}

If the roots are thoroughly protected, a voyage from Europe to Biltmore, though it may take six weeks, will not injure the plants. Plants are loosely put together in bunches of one hundred to two hundred, are plaeed in baskets or open crates, the roots in the center, the tips at the cireumference: Layers of plants alternate with layers of damp moss. Seedlings packed tightly, especially in boxes, are apt to mould.

Plants merely taken to a nearby plantation on wagons should be well covered with branches, moss or sacks, and sliould be sprinkled during transportation. Ball plants do not need paeking unless balls are very loose, when burlaps are necessary. One hundred Yellow Pine ball plants, with balls ten inehes square, make up a two-horse load. Fifty thousand seedlings without balls and well watered, or eighty thousand seedlings slightly dampened, usually make a wagon load.

Under adverse elimatic conditions, the use of plants planted in minute paper bags-like those used in raising Eucalypts-is highly advisable.

Experiments made at Biltmore with one-year White Pine seedlings are to the effect that seedlings having the roots exposed to air and wind

for 10 minutes, had a death rate of $5 \%$
for 20 minutes, had a death rate of $10 \%$
for 30 minutes, had a death rate of $70 \%$
for 45 minutes, had a death rate of $90 \%$
for 60 minutes, had a death rate of $100 \%$

'The experiments prove that the utmost care is necessary, under adverse conditions, to preserve the vitality of the roots during the act of transportation.

\section{Paragiraph XXIII. Common methods of plant- ing seedlings.}

\section{A. Planting in furrows.}

The furrows should be made deeply with a sub soil plow. The plants are distributed, at proper distanees in the furrows. Then another furrow is at once given with a turning plow, throwing the needed dirt over the plants, which are thereafter adjusted by hand and pressed into proper position.

This is a quick method of planting, but is practical only on 
prairies or on abandoned fields. It involves the langer of reckless spreading of roots and of loose imbedding of the plant in loose soil. The plants are also apt to be placed too deep and to be shaken badly by wind. The method, however, yields good results in case of

I. Stump planting (Oak, Locust, Catalpa).

II. Planting many one-year-old seedlings (so that a large percentage might be lost without great damage in the end).

III. Plants not injured by deep planting (not for White Pine and Spruce). Plants placed too deep form a second root system close to the surface and develop a bushy bole, useless in forestry, pleasing in a garden.

At Biltmore, the furrow method was used by Pinchot at the Shiloh Crossing plantation. A modification of the furrow method was used at the Rice farm in 1903, where deep furrows were drawn, the plants inserted by hand, covered by hand and adjusted by hand. A planting machine (Dr. Fernow's and Rodman's), resembling a tobacco planting machine, is not used.

B. Planting in holes. The holes are either holes dug with the spade, or clefts wedged into the soil. Most planters mulch the roots in loamy water so as to increase their weight and so as to reduce their spread before insertion into the hole. The root fibres suffer from this mulching, however, being braided unnaturally. The root tips should not be bent upward. The depth and width of the hole should correspond with the actual size of the root. Several plants might be placed in the same hole to save expense. Theoretically it is best to place each plant in the center of its hole. At Biltmore, however, planting in the lower edge of the hole is preferred because:

I. No root is bilaterally developed.

II. Planting at the edge is the best preventive against deep planting, the planter holding the plant with the left hand at the point of differentiation against the edge of the hole, when drawing with the right hand the dirt required to fill the hole.

III. Such plants are firmly imbedded and are less shaken by the wind.

On forest soil it is wise to place the top dirt dug from the hole around the root tips, and the bottom dirt of the hole close to the surface. The workmen should be shown daily by the forester how to plant. It is of the utmost importance to pulverize and loosen the dirt first, and to then press and beat it tightly with fist, heel or mallet around the roots. Some planters give a trifle of forest humus into the hole; others carry fertile garden dirt in baskets to the plantations. The placing of stones on the hole (as 
refrigerators) is recommended. One man's work at hole digging per day is 300 to 3,000 according to root-size and conditions of soil.

\section{The seedling must stand, after planting:}

I. Firmly, the dirt being tightly packed around its roots, so that it cannot be shaken and so that the roots may establish their sucking contacts.

II. Naturally, the roots retaining the same manner of spreading and ramifying which they had in the nursery.

III. Erect and just as deep as it stood in the nursery (exception: barren sand).

\section{Paragraph XXIV. Special methods and tools used for planting seedlings.}

A. Biermans spiral spade, costing $\$ 2.00$, is pointed parabolically, the blade being $7 \frac{1}{2}$ inches long and 5 inches wide. When used boringly, this spade forms a parabolic hole and loosens the soil. With the left hand the seedling is pressed against the side of the hole, while the right hand places some sod ashes (See Par. XXIX, D. VI.) immediately over the fine root fibres. Then the best part of the soil is used to fill the near half of the hole, and the poorest for filling the far half. The instrument is adapted to hardened soil. On wet and binding soil, the dirt clogs in the curves of the spade. Capacity per hand per day in Germany 320 plants.

B. The Planting Dagger is used for Yellow Pine seedlings one or two years old, to be planted on sandy soil. The dagger is three inches longer than the longest root. It is made of wood, iron shod at the point. It makes a narrow, funnel-shaped hole, which is closed by pressure from another hole made a few inches from the first. On loose, sandy soil it is wise to plant Yellow Pine seedlings deeply-up to first needles-since lellow Pine is not affected, in that soil, by deep planting. Daggering is the cheapest possible method for planting Long Leaf Pine, Jack Pine, Lodgepole Pine, etc. Capacity 800 to 900 per day and hand.

C. The Buttlar Iron, one much used for thrusting holes into the soil, is now in disfavor since it causes the seedlings to be inserted into holes having walls as impenetrable as those of a flower-pot. Only plants one or two years old can be thus planted (" cleft planted"). 
D. The Wartenberg Iron consists of a sword is inches long, attached to a heavy handle. Price $\$ 2.25$. Similar irons were made at Biltmore out of three-inch wagon tire, at a small cost. A deep cleft is made by the iron in which tap-rooted seedlings are readily inserted. On binding soil, however, or in a broomsedge field, the use of this iron cannot be recommended.

E. The planting hammer is used to make small holes for small roots. The iron part of the hammer is about five inches long. The planting hatchet, a similar make, may be used to advantage for planting one-year-old plants. The holes are closed by beating the dirt round the holes with the back of the hammer or with the hatchet.

F. Von Alemann constructed a very heavy square spade which is pushed and drawn in a particular way, like the lever of a handcar on the railroads, so as to make the lower part of the hole wider than the middle part, the cross-section of the hole forming an $\mathbf{X}$. If Oaks are planted, an extra hole is made at the bottom of that made with the spade, by means of a long dagger in which the tap root of the oak is to be imbedded. The hole is closed by pressure from above. It seems doubtful whether the soil will close entirely over the roots unless it be sandy. One man plants 580 Oaks two years old or 1,270 Yellow Pines two years old with this instrument on plowed ground.

G. The Planting Beak, constructed by Barth, makes and empties a triangular hole, removing the dirt filling the hole. Plants one or two years old are placed along the vertical side of the hole. Then the dirt kept in the beak is filled in. The instrument is $31 / 2$ feet long and weighs 15 pounds. It is said to be superior to all cleft planting tools, whilst it works just as cheaply on loose soil.

H. Planting under sod cover. (Von Alemann). Two sods are turned over, like the covers of books, and laid back, upside down, without loosening the "hinge" of the sods. The soil in the hole is deeply worked with a spade. In the middle of the hole the plant is placed, with the roots spread as much as possible within the entire hole. Then the two sods are turned back into their original position, so that the seedling stands between them. This is a good method on ground where frost is to be dreaded, and is used for Ash, Alder and Water Birch one to three years old.

I. Mound Planting (Manteuffel). Small mounds are made consisting of rich nursery soil to be carried in baskets to the plantations. The plant is placed into the mound, its roots touching 


\section{A IERICA I S IL VICULTURE}

the regetable mould underneath. The mound is covered with sods to prevent erosion. The method works well on very dry and hard ground. About 100 plants are planted per day and per man after this method. Its advantages are:

I. The vegetable eover of the soil, by its disintegration, furnishes food for the rootlets.

II. The quality of the soil surounding the roots is very good.

III. The soil in the mounds is kept moist with condensed atmospheric vapor, owing to its greater porosity.

IV. The planter is not likely to plant the seedling too deep.

The method is also applied on very wet soil. The mounds may be replaced by ridges. Experiments have shown that planting in mounds does better in years of drought than planting in holes.

Modifications of the Manteuffel method are in common use. Ordinary soil dug out at the planting site may be used to make the mound; or, where there are heary sods, a sod is turned upside down and left to rot for a year. The mound thus made is rich in plant food resulting from the disintegration of root fibres and vegetable matter.

Disadvantages of mound planting are:

a. The mounds are easily washed away on slopes unless under cover of mother trees.

b. The best soil is washed out if the mound is not covered with sods, stones or brush.

c. Insects and mice find hiding and breeding places in the sodcovered mounds.

d. Mound planting is very expensive.

J. Ballplanting, with Charles Heyer's hollow cylinder spade.

The cylinder spade can be used to best advantage on binding soil. It lifts the plant (seedlings, notably conifers one or two years old) from the nursery without loss of roots and prepares for it a hole on the ground to be planted having the exact form of the ball of dirt adhering to the roots.

The method is particularly safe and scems particularly adapted for prairie planting since it protects the seedling before, during and after the act of planting; since it prevents the seedling from loosing its foothold in the soil under the influence of high winds; since it allows of planting at almost any season of the year.

On stony soil, the cylinder spade cannot be used. Edward Heyer's "cone spade" facilitates the transfer of larger seedlings with heavier balls of dirt from the nursery or from the woods to new plantations. 


\section{Paragraph XXV. Season for planting seedlings.}

Factors influencing the season are:

Local climate.

Labor available.

Time available.

Species planted.

Theoretically, seedlings should be planted during the period of inactivity of roots and buds, or in mid-winter. This theoretical demand, however, in a Northern climate, canmot be carried out, the ground being frozen at that time. Hence the choice remains between planting in late fall and planting in early spring. After Engler, roots show two periods of active growth, viz.: a spring-andsummer period inlluenced by soil moisture, and a fall period inlluenced by soil heat. The growth of the roots during August and September, between the two periods mentioned, is very weak.

In spring, the growth of the roots starts in March and April and shows the highest activity in May, June and July.

\section{A. Spring Planting.}

The seedlings are planted before the opening of the buds. The moisture left in the soil by the melting snow is very favorable to their growth. Objections to spring planting are:

I. Scarcity of labor, unless forest planting begins at a time at which fields are too wet to be worked.

II. Larch, Maple, Cherry, Tulip tree and Birch sprout so early in spring that it is impossible to adopt spring planting in their case.

III. Moist ground, hummocks and swamps are not accessible in spring.

IV. The soil is not packed as tightly around the roots on the arrival of spring as is the ease in fall planting.

\section{B. Fall Planting.}

Fall planting is preferred on wet areas and in the case of early sprouting species. The disadvantages of fall planting otherwise outweigh the benefits combined therewith.

I. Seedlings planted in fall are apt to be heaved up by the winter's freeze.

II. The severe winds of the winter loosen the foothold of conifers planted in fall.

III. Fall-planted seedlings are more subject to late frost, opening their buds some ten days earlier than spring-planted seedlings.

IV. On weedy soil, fall-planting is handicapped by the presence of a rank growth of weeds which has rotted down at the arrival of spring. 
In the Southern states, even at Biltmore, planting in January and February is very feasible, perhaps advisable in average years.

Ball plants can be planted at any season of the year.

In countries of periodical rainfall (California, Oregon, India and Porto Rico) it is best to plant just before the beginning of the rainy season.

In swamps, summer planting or early fall planting is a necessity.

\section{Paragraph XXVI. Cultivation of plantations.}

A. Practice: The European forester cultivates his plantations but rarely for the reason that his plantations are made immediately after lumbering, when the rootwork and the stumps on the ground render eultivation difficult. Under the prevailing conditions of soil (humus, porosity), cultivation is usually not required for the success of a plantation. Irregular plantations cannot be eultivated.

The forester afforesting sand lands obviously objects to cultivation.

The forester afforesting swamps finds cultivation impracticable.

B. Advisability: Cultivation is advisable:

Where there is neither humus nor rootwork in the ground;

Where the soil, like prairie soil, is compact and hard, lacking in aeration, porosity, eapillary power, hygroscopicity;

Where competing herbaceous weeds threaten to smother small seedlings;

Where mice or soil breeding insects prevail, which are disturbed, exposed or killed by continuous cultivation.

\section{Frequency.}

The forester may cultivate up to three times per annum, during one, two or more years-sometimes till the leaf canopy overhead secures for the soil a solid layer of humus by dense shading.

\section{Tools.}

A bull-tongue plow is used, on rough ground, for plant rows placed less than thee feet apart.

Cultivators are used, as in agriculture, where the soil is loose, and where the rows are far enough apart and the ground is free from stumps or roots or boulders.

Hoes are used, where but a plant here and there requires culti- 
vation, where labor is cheap and where the soil does not allow of using teams and machinery.

Mules and horses are muzled to protect broad-leaved seedlings from being browsed.

\section{Paragraph XXVII. Prairie planting in particular.}

A. The prairie exhibits climatic differences as marked as those prevailing between the State of Georgia and the District of Labrador.

"General preseriptions for prairie planting" are impossible, owing to these climatic diversities.

B. The species used must be adapted to the quality of the soil, the intensity of summer heat, the duration of the summer, the soil moisture, the air moisture. Native trees should be given the preference in case of doubt.

C. Prairie plantations are meant either for production of farm timber (ties, posts, etc.), or for shelter to stock, house, orchard and field.

D. Species recommended for prairie planting are:

I. For Canada:

White Spruce, Cottonwood, Balm of Gilead, Box-elder, Green Ash, Russian Poplar; further Yellow Pines.

II. For Minnesota and Dakota:

Cottonwoods, Soft Maples, Willows, Ashes, Box-elder, Tamarack in swamps, Bur Oak along rivers.

III. For Nebraska and Iowa:

'The same species and Red Cedar, Russian Mulberry.

IV. For Kansas, Arkansas, Oklahoma and Missouri:

Osage Orange, Black Loenst, Hardy Catalpa, Post Oak and White Oak.

E. Naturally we should expect the Xerophytic species, like Yellow Pines, to do best in the prairies, and the old stumps found buried in the ground bear testimony to their possibilities. Being evergreen, the Pines protect the farmers best from blizzards. Still, just Pines are most apt to meet with distress previous and after the act of planting. Ball planting should be tried. The European Pinus montana resists wind particularly well.

F. Preparation of soil: It is best to prepare the soil thoroughly by several years' field crops. Deep plowing is required 
(Toumey) in the fall previous to planting and in the spring of planting.

G. Treatment of plants: The seedlings arriving at the farm should be removed from the package; heeled in under shade, protected from winds and sprinkled if frost is not to be feared. Toumey wishes to puddle plants before heeling, and desires to plant the conifers invariably after the broad-leaved kinds.

H. Planting: The planter must wait patiently for proper weather. Thorough protection of the roots during every moment of the act of planting is essential. Each individual must be planted by itself,-no dozen methods! The plants should be set closely within the rows; the soil must be packed tightly around the roots. Reversed sods or stones may be used to ballast the roots and to prevent the wind from shaking them loose.

I. Cultivation: Cultivation is necessary up to the time when the trees cover the ground fully, littering it with humus. Where barefrost is dreaded, cultivation should end in late summer.

\section{Paragraph XXVIII. Methods of obtaining plants for planting.}

A. Seedlings are obtained frequently from the woods nearby, a method which seems to recommend itself as cheap and natural. It is a fact, however, that the roots and the buds of wild seedlings are badly adapted for the purpose of planting. The former are far-spreading; the buds are weak and few. In addition it is risky to take plants from the shelter of mother trees suddenly onto open ground. The use of wild seedlings over two years old is particularly unsuccessful. The failure of the timber culture act to prove efficient is largely due to the use of wild plants in prairie plantations.

At Biltmore, seedlings of Yellow Poplar, Yellow Pine, Ash and Maple are often picked up in the woods, on logging roads, with a spade and removed to the nurseries. Such seedlings are taken at a very young age, without loss of dirt, to murseries placed under lath screens. They are never removed directly to open plantations, with the exception of ballplants of Yellow Pine.

\section{B. Purchase of plants from commercial nurseries:}

During the last twenty-five years, a number of financially strong commerical nurseries have arisen abroad which, buying seed 
cheaply, located on suitable ground at good shipping points, enjoying many year's' close acquaintance with the needs of Sylviculture, have supplied the varions German forest administrations with eheap plants of a superior grade. The Biltmore Estate has often obtained plants raised by Heins Sons, Halstenbeek, near Hamburg, notably White Pines, which have been very successful in spite of a sixweeks' voyage. On the other hand, American tree nurseries usually prepare plants but for ormamental purposes and not with a view of fostering the development of the tree bole.

Since the rangers and the helpers in forest planting should know the sylvicultural needs of the seedlings, it is surely wise to offer them object lessons at home through self-administered nurseries.

\section{Nurseries proper, in charge of the ranger.}

Where mice are much feared the nurseries should be surrounded by a deep, straight-walled ditch. Fences are made of wire, lath, rails, ete., differing in material, strength, height and fineness of mesh according to the enemies locally dreaded.

Proper nurseries yield the largest percentage of seedlings from a given quantity of seeds. The seedlings raised therein have a better, more compact and more fibrous root system than wild plants. Expensive and exacting species should always be raised in "forest gardens."

There may be distinguished:

Nurseries under tree cover.

Shifting nurseries.

Permanent nurseries.

I.. Nurseries under tree cover form the exception, being required only for the production of seedlings of tender species; notably of Hemlock, Hard Maple, Beech. The mursery is formed by a polewood heavily thinned and dug over with the spade. Here Beechmuts are planted broadcast or in furrows and the seedlings removed when two years old, without transplanting. Hard Maple and Hemloek should be raised as in open nurseries.

It is a noteworthy fact that broad-leaved kinds often thrive best under conifers (Oak and Beech under Pine) and conifers best under broad-leafed kinds (Spruce best under Beech, Maple, Bireh). None but theoretical explanations can be given for this observation, the best explanation being the difference in the enemies attacking such spècies.

Objections to nurseries under tree cover:

a. Soil preparation is costly and insufficient. 
b. Plants raised cannot be planted in the open without loss.

c. Nurscries under tree cover suffer badly from mice and squirrels and obtain insuflicient rainfall. On the other hand, weeds and grasses are kept down by the shelter overhead.

Nurserie under tree cover form the exception, not the rule.

II..Shifting versus stationary nurseries.

The adrantages of stationary forest nurseries over shifting forest nurseries are:

a. Reduced cost of tilling.

b. Reduced cost of fencing.

c. Reduced cost of supervision.

On the other hand, stationary nurseries suffer from:

1. Excess of weeds.

2. Higher cost of transportation of seedlings.

3. 'Large needs of artificial fertilizing.

4. Danger from mice, insects and fungi for which such nurseries act as ineubators.

For raising ball plants, the shifting mursery is undoubtedly best; otherwise the selection between shifting and permanent nurseries depends on local conditions, such as the price of manure and of fencing, eharges for transportation, etc. Seed plantations made on open ground are often used as shifting nurseries-especially so in the case of Yellow Pines.

\section{Paragraph XXIX. Permanent nurseries in par- ticular.}

A. The size of "forest gardens" (the German word for permanent nurseries) depends upon the quantity, the age and the size of the seedlings annually needed; further, on the presence or absence of transplanting beds, fallow beds and patlis between the beds. A regular forest management employs forest gardens fitted with:

I. Transplanting beds, their total size being equal to transplanting space by number of plants yearly needed by number of years which the transplants are left in such beds.

II. Seed-beds, their total size being equal to one-fourth of size of transplanting beds for one age class by number of years which the seedlings are allowed to stand untransplanted.

IJI. Foot paths and roads equaling $30 \%$ of I and II.

IV. Fallow beds equaling $100 \%$ of I, II, and III, if seedlings 
and transplants are left for one year in their beds; $50 \%$ of $\mathrm{I}$, II and III, if left for two years; and $33 \%$, if left for three years.

B. Form of beds. Beds are usually four to six feet wide, separated by paths one or two feet wide, the beds preferably elevated over the paths by from three to twelve inches, so as to eheck the migration of insects, mice and moles; and so as to allow of better aeration of the soil. Sometimes the beds are kept in board frames, an expensive though useful arrangement.

C. In selecting the site of a nursery the following factors must be considered:

I. Soil: A sandy loam or marl is best for seedlings. The correct degree of looseness is secured by mixing sawdust, spent tan, humus, ashes and weeds with the mineral soil. The soil should have no stones, in order to allow of proper seed planting and in order to facilitate the treatment of the plants.

II. Exposure: The best exposure is a gentle northwest slope. The bottom of a valley is too frosty in spring. Southwest and southeast slopes are subject to rapid atmospheric changes. Eastern aspects invite damage by frost.

III. Proximity to water and possibility of irrigation.

IV. Accessibility for laborers and distance from ranger's house.

D. Fertilizing: Stationary forest gardens require continuous fertilizing. Crops of seedlings exhaust the soil like crops of grain.

The following table exhibits, in pounds per acre, the amounts of fertilizing matter aunually consumed by Pine seedlings, Pine poles and erops of rye.

\begin{tabular}{|c|c|c|c|}
\hline Fertilizing matter. & $\begin{array}{l}\text { Yellow pine } \\
\text { one year old. }\end{array}$ & $\begin{array}{l}\text { Yellow pine } \\
\text { eighty years old. }\end{array}$ & $\begin{array}{l}\text { Crop of } \\
\text { rye. }\end{array}$ \\
\hline Phosphorie acid & 9.8 lbs. & $1.7 \mathrm{lbs}$ & $16.7 \mathrm{lb}$ \\
\hline Potash ...... & 20.7 lbs. & $2.8 \mathrm{lbs}$. & $24.2 \mathrm{lb}$ \\
\hline Calcium ............. & $17.2 \mathrm{lbs}$. & $10.1 \mathrm{lbs}$. & $9.7 \mathrm{lb}$ \\
\hline Magnesia . . . . . . . . & $3.0 \mathrm{lbs}$. & $2.0 \mathrm{lbs}$. & 4.21 \\
\hline Sulphuric acid .... & $0.0 \mathrm{lbs}$. & $0.3 \mathrm{lbs}$. & $1.1 \mathrm{l}$ \\
\hline
\end{tabular}

The following fertilizers are used in forest gardens:

I. Animal manure, which is considered best. Cattle manure is preferred to horse manure; on clay soil, however, horse manure is better. Heavy weeds come up from stable manure which has not had time to fully decompose.

II. Commercial fertilizers: Experiments conducted with superphosphate, bone meal and so on have failed to yield conclusive 
results. The best kalium fertilizer seems to be kainit (kalium chloride); the best nitrogen fertilizer is saltpeter.

After Ton Schroeder, the following quantities of phosphates, potash and nitrates are needed to raise $4,000,000$ plants on an acre of nursery:

520 lbs kainit.

60 Ibs. superphosphate.

320 Ibs. whale guano.

III. Humus, the natural forest manure, is the cheapest fertilizer obtainable in the woods. Mould of Pines mixed with that of broad-leaved species is best. Mould just one year old is said to be richest in the bacilli favorable to tree growth, and to be devoid of filiform fungi disastrous to plants.

The weeds removed from nurseries furnish, through their decomposition, a valuable humus.

A mixture of humus with street sweepings, kitchen refuse, loam, burned lime, etc., is often placed in heaps near the nurseries. The heaps are kept in a rotation so that the heap made in 1913 is used in 1916. The heaps are stirred up repeatedly so as to be acted upon by the air.

IV. Vegetable matter other than humus. Vegetable fertilizer may be obtained by raising, on the fallow beds, during the fallow year, cowpeas, clover, lupine (the latter on sandy soil) and other leguminous plants, all to be plowed under in fall.

Leguminous plants increase the nitrogen in the soil.

V. Wood ashes: Excessive use of wood ashes is disastrous to sprouting plants, especially oh sandy soil. Besides kalium, wood ashes contain from $5 \%$ to $20 \%$ of phosphoric salts. Wood ashes should be used, however, moderately in Yellow Pine nurseries.

VI. Sod ashes are recommended where other fertilizers are too costly. Sods of grass, of weeds or of huckleberries are dried and the majority of the dirt is removed. From the sods is constructed a kiln resembling a charcoal pit, wherein layers of sod alternate with layers of brushwood, waste, thimnings, etc. The kiln is coated with sods and wet dirt. Kilns burn, according to size, for from two days to two weeks. The sod ashes contain all mineral fertilizers needed; have great hygroscopicity and are free from insects, fungi and other bearers of plant diseases.

Sod ashes should be exposed to the atmosphere for a year before use, and shonld then be well mixed with the top layer of nursery dirt. 


\section{Paragraph XXX. Seed planting in seed beds.}

Seedbeds: Prescription for preparation: Plough and erossplough to a depth of one foot; mix manure well with soil; heap the dirt taken from the paths on top of the beds; remove stones.

Seeds are planted either broadcast or in drills to a depth generally equaling their longest dimensions.

A. Broadcast planting is always used in commercial nurseries while the sylviculturists use it merely for sceds of small germinating percentage (Birch, Elm, Beech, Alder and Yellow Poplar) or in case of light grained seeds which do not allow of any eovering.

Broadeast planting is permissible if seedlings are kept in the bed one year only. Economy in size of nursery and less weeding are the advantages of broadeast plauting.

Witl the lielp of a roller or, better still, of a heary plank, the surface of the seed bed is pressed down until an even surface is obtained. Then the seeds are planted, dirt or fertilizer or sod ashes sifted on top, and the surface of the bed again pressed down as before. To prevent the formation of a crust, a cover of moss or leaves is often given, to be removed before the time at which the cotyledons are expected to appear. Better than moss or leaves are coverings consisting of Pine branches (exception: on Pine seeds).

B. Planting in rills. The rills are from one-fourth to three inches wide; made with a "rill board," a plank well seasoned to which mouldings are nailed. These mouldings may either be square or triangular in their cross sections.

The rills are from five to ten inches apart. Double rills are preferred, lately, in Germany. In order to economize in the use of fertilizer and in order to obtain a compact root system, trenches are sometimes made and filled with particularly fertile soil, at a distance apart equaling that of the rills. These trenches are made with a special "trench hoe," triangular in shape. The seed is put in the rill with the hand, with the help of a reduplicated playing card, a bottle of seed or, better, a stick $2^{\prime \prime} \times 4^{\prime \prime}$ grooved on one side and as long as the width of the bed, or, best of all, a hinged gutter into which the seeds are filled by "thimblefuls" or "spoonfuls," evenly distributed in the base of the gutter. The gutter is placed over the rill and opened by pressing the two sides together, when the seeds drop through the "slot." To insure an even distribution of the seed in the gutter, small niches may be provided at short, equal intervals at the base of the gutter, the 
aggregate size of the carities corresponding with the quantity of seeds to be planted in each rill.

Hacker's seed planting machine is used, in German forest nurseries, on an increasing scale for the seeding of coniferous seeds, be it broadeast, or in rows: A wedge-shaped trough receives the seeds; beneath the wedgepoint is an opening allowing the seeds to drop into the horizontal grooves of a metal wheel; the grooves may be closed, and the dropping of seeds into them thus prevented partially, by a series of brass rings fitted over the wheel; the machine is pushed over the seedbed, the wheel is caused to rotate, and the seels are conveyed by the grooves into the top layer of the soil; two small brushes prevent the seeds from escaping too readily, and also keep the wheel free from dirt. To the right of the seed wheel is a small roller, which presses the seeds into the ground, or else levels the surface of the bed to be planted.

Advantages of rill planting:

I. Economy in seed.

II. Stronger plants of more compact form grown at proper intervals apart.

III. Economy in manure.

IV. Seeds put at proper depth.

$r$. The foot of plantlet can be easily covered with moss or leaves.

VI. Weeding is made easy.

Unless experienced help can be had, rill-planting is certainly preferable to broad-casting. Undoubtedly, howerer, insects, mice and moles following the rills do greater damage in rill than in broadeast planting.

The quantity of seed per square foot of seed bed Aepends on the number of seeds in a pound; the germinating percentage; the quality of soil; the number of years which the seedling is meant to stay in the beds; rapidity of growth. Oak $2 \%$ of a quart; Beech and Chestnut, $4 \%$ of a quart; Locust, Ash, Maple, Elm, Birch, 30 grains; Alders, 45 grains; Fir, 150 grains; Yellow Pine, 15 grains; Spruce, 20 grains, 'l'amarack, 30 grains; avoirdupois-all per square foot.

The figures given are illustrations, not preseriptions.

Heary seeds (nuts) are usually dibbled in, with a "dibbling board." 


\section{Paragraph XXXI. Transplanting in transplant- ing beds.}

A. Transplanting is expensive. It must be done at a time when forest-labor is anyhow fully occupied. Transplanting is, therefore, resorted to only

I. In case of expensire seeds or seedlings.

II. In case of slow growing seedlings.

III. In case of plants exposed in the open to severe dangers (drought, frost, game, mice, insects, weeds).

B. To avoid transplanting, the following alternatives are used:

I. The offspring of very cheap seeds (German Spruce) is " $\sin$ gled out," weaklings or individuals standing crowdedly being pulled out by hand, or being elt out by scissors.

II. "Root pruning" is used to enforce a compact root system by cutting off, with a sharp spade, far-spreading roots, or long tap roots.

The transplanting distance is, at least, three by six inches and is governed by rapidity of growth expected and by the number of years which the transplant is to be left in the transplanting bed.

Transplants are set in clefts in the transplanting bed made with the help of a transplanting dagger, or are placed into trenches made with a hoe or spade. So as to regulate the operation, planting boards are often used, along which the seedlings, whilst pressed into equidistant slight grooves, are held in proper position.

Professor Toumey's planting board, used in many American nurseries, catches the seedlings to be inserted between the upper and lower lid of two timbers, the lids holding the tops of the plants, with the roots hanging free, as if they were pressed between the covers of a book.

Forstwart Schlag's planting board holds the seedlings between two timbers connected by iron pins. Strong rakes, with oblique handles, are used to make the trench receiving the seedlings.

Forstmeister Hacker's planting board is similar to Schlag's.

Transplants are often left for but one year in the tramsplanting bed, although the act of transplanting weakens the plant temporarily, thus checking the first year's growth in the transplanting bed. Conifers should not be transplanted more than once. Hardwoods are rarely transplanted for forest purposes more than once, excepting the Ash, saplings of which are used for planting in inundation districts along rivers. 


\section{Paragraph XXXII. Protection of nurseries.}

A. Against drought: Lath covers, cloth covers, branches, cornstalks, top covering of slabs, laths, ete.; eultivating rows of plants; watering which must be continued if once begun.

B. Against frost: Same measures as in "A" inclusive of watering; smoking fires; pressing seedlings lifted by frost back into the bed; no weeding from September on.

C. Against excessive rain (which washes the plants out, or splashes them with mud-pants, or incrusts the surface): Top dressing of leaves, moss or Pine branches; "combing" mud-pants off the seedlings; lath or brush covers.

\section{Paragraph XXXIII. Nursing in nurseries.}

A. Weeding: Weeding is facilitated in nurseries by a regular arrangement of the plants and by narrow beds. Tools are: Knife, fork, hoe or speeial weeding wheels. Weeding should be stopped a month before frost occurs. The purpose of weeding is not only the removal of competitors; it is also the aeration of the soil.

Weeding can be dispensed with in dense, broadcast seed beds; in thinly stocked beds planted broadeast it is most necessary and most diffieult.

B. Cultivation: Cultivation in the transplanting beds of the commercial nurseries is done by eultivators drawn by a horse. Cultivation in forest nurseries proper purports to break the crust forming under the influence of heavy rain. Usually the act of weeding cultivates the soil as well. Cultivation is most easily effected by drawing some strong nails driven into a stick along each rill. This cultivation, at the same time, disturbs and seares away mice, voles and insects.

C. Carpeting the intervals between rills or rows.

Reversed moss, spent tan, sawdust, straw, hay, twigs (always of another species), poles (not fresh cut pine poles, which are ineubator's to snout beetles) are often laid between the rills or rows so as to preserve the moisture, to prevent mud-pants from forming on the stemlets and to check weeds. These earpets, however, harbor mice and insects. Large leaves in the carpet threaten to smother young seedlings if blown upon them.

D. Trimming. The top shoot when killed by early frost or drought might be cut off. In no other case must it be touched. 
The side branches of broad-leafed species and of winterbald conifers might be clipped before or after planting and transplanting so as to reestablish the previous equilibrium existing between water sucking power of the roots now checked by transplanting and water evaporation from the crownlets left unchecked by planting. Species having a heavy central pith column should not be trimmed too close to the stemlet (Ash, Catalpa, Maple). Ash and Catalpa are apt to form forks which may be prevented by timely trimming.

Large broad-leaved plants planted in furrows often die, when shaken loose by winds. They may be saved if cut to the ground previous to June 15th.

\section{Paragraph XXXIV. Special nursery methods proclaimed by renowned sylviculturists.}

A. Biermans' method: Peel the soil cover from an area four times the size of the seed bed and burn the sods thus gotten into sod ashes. Leave them over winter. In spring, mix one-half of the sod ashes with the stirred-up top dirt of the intended seed bed. Spread the other one-half pure on top of the bed. Smooth the surface of the bed and press it with a board. Spread seeds broadcast as close together as possible, so that the soil is hardly visible between the grains. Cover seeds with sod ashes sifted on top, and press the cover down with a board. Transplant the young germs in June. Shorten the taproot of Oaks by eutting with a sharp knife. Oak nurseries should be underlaid with impenetrable soil. Yellow Pine and Larch should be used in the open when one year old; all other species two to three years old.

This method yields very well rooted seedlings. The use of sod ashes is, perhaps not an essential feature of the method; fertilizer or manure might be taken instead. The striking point is the transplanting of germs in June.

B. Von Buttlar method: Von Buttlar wants to raise long roots, not compact roots, for use in sandy soil. The nursery is worked to a depth of three feet, the bottom soil being brought to the surface. Larch, Fir and Elm seed are planted broadcast; all other species in rills. No transplanting. All species are used one or two years old.

C. Von Manteuffel method: The plants required by Manteuffel must have short, flat roots. Consequently, the best soil in the nursery should be the top soil, and the ground underneath should not be worked to any depth. 


\section{A IERICAN SYLVICULTURE}

Remove the top layer of the soil, by peeling, and beat the dirt out of the peeled sods onto the seed beds. Mix it with the dirt of the underground in fall. In spring, burn the sods and other vegetable matter at hand on the leeds, mixing the wood ashes thus obtained with the top soil. Fipruce shall not be transplanted and is to be used when two years old. Fir and all broad-leafed species must be transplanted.

D. Von Ueblagger method: Regardless of speeies and age and size, all seedlings are dug from all beds, before the frost sets in, and are kejt in a heeled-in position, duly covered, all winter long. The beds free from seedlings are impregnated and fertilized by the atmosplere during winter. The seedlings are ready to outplant or transplant at once in spring. The results obtained are excellent.

\section{Paragraph XXXV. Raising and planting hard- wood seedlings.}

Beech: U'sual age of plants fit for use, two to five years. Transplants rarely used. Ball plants very successful. Bunch planting best, especially for underplanting. Do not cut stemlet to the ground and avoid pruning. Planting in open elearings hardly successful. Beech best for underplanting. Instruments used are: boe, spiral spade, deft irons. Almost light demander on poor soil. Beech is exacting (good soil and moisture).

Black Locust: Seeds should be planted two to two and onehalf inches deep, an exception from the usual rule as to the depth of planting, considering the small size of the seed. Drills eight inehes apart. Germinating pereentage of seeds very high. Seedlings are fit for planting when one year old. Uslally, however, they are left in the.seed bed for two years, and are then planted directly in the open. The planting of stumps and fall planting are strongly recommended. Plantations handicapped by twigboring moth (Eedytolopha species) and by voles. Loeust grown in the open is inferior to forest grown Loeust.

Linden: Is usually planted in the open as a transplant three to four years old, or as a ball plant two or three years old. Spring planting. Good soil required. Pruning of branches a necessity. Plantations in Biltmore made in '98 on splendid soil, but without cover overhead, were slow to develop. 
Oaks: The nursery treatment differs greatly according to local likes and forestry authorities relied upon. The treatment of the tap root is a continuous point of dispute. Manteuffel cuts the tap root one and one-half inches below ground (just as the voles did in Biltmore nurseries). Buttlar ties a knot into the root. Alemann forbids any erippling of the tap root, making an extra cleft in the planting hole to receive the tap root. Levret prevents the development of a tap root by placing the acorns on macadam, covering them with one inch of dirt. The ground underneath the macadam must be hard.

Large areas of Oak planted in Northern Germany with the tap root removed prove the success of Manteuffel's method. The hollow borer eamnot be used. Trimming of branches is all right. Roots should be prumed, after Fiirst, with a sharp spade at six inches below ground in the second spring. Spring planting is best. Some planters remove the first germ of the acorn ("offgerming") with a view to stopping the development of the tap root. Stump plants do very well, especially in the coppice woods. Usually seedlings one and two years old are planted. The use of saplings, transplanted repeatedly, is not advisable. Cleft planting of seedlings on broomsedge fields at Biltmore proved umsuccessful; the weeds choking and the rabbits eating the seedlings. Cleft planting in eutover woodlands, however, on fairly loose soil is a method to be strongly endorsed. In France the clefts are made inclined, not vertical; saplings 20 years old do not show any crooks due to the method. Planting of scedlings or of young transplants in spade holes, in furrows or in clefts made between the lid and the pit formed by reversed sods prove successful at Biltmore. Young plants are not subject to lifting by frost nor do they suffer from drought. The nursery should not be worked deeper than one foot while the success of the final plantation largely depends on looseness of ground at a greater depth. Generally Red oak is more vigorous in early youth than White Oak. At Biltmore, Chestuut Oak is the best species for abandoned fields. The Yellow Pines are valuable as nurses or ushers, when planted with or in advance of the Oaks.

Chestnut: Soil well worked to a depth of sixteen inches, potash a necessity, lime disastrous. Seedling planting (plants one or two years old) forms the rule; planting of stumps is also good.

Since Chestnut is very sensitive under changed conditions of growth, ball planting is probably the best method. Seeds are often kept in the burs over winter, or in layers alternating with layers of dry sand. Immediate fall planting, however, is best. Nuts are 
planted in drills two inches deep two inches apart, the rows of drills six to twelve inches apart. At Biltmore planting of seedlings has met with continuous failure. Planting under cover or under an usher growth is probably advisable. Chestnut is exacting, needing atmospheric as well as soil moisture.

Tree Alder: It is usually planted as a transplant three to five years old. Yearlings are too small; seedlings two years old can be ball planted. Trimming allowed. Seeds planted broadeast on the beds, one-fourth inch of dirt on top. Sprinkling necessary. No protection against atmosphere needed. On swampy ground, fall planting of transplants is best. Since Alder is particularly well adapted to thrive on non-aerated soil, it should be tried for prairie planting.

Birch: Seeds very poor in percentage of germination. Seeds must be covered very slightly or better perliaps, must be beaten with a shovel into the nursery soil after broadcasting. Formation of crust over seeds is best prevented by a cover of Pine branches. Under lath screens, the germs are apt to damp off. Seedlings are planted either as two year olds, with or without balls, or as trans. planted stumps three to five years old. Birch is sensitive to deep planting; is not affected by heat, frost or drought.

Ash: The easiest species among hardwoods to raise, plant and transplant. Planted as a seedling one year old or transplanted up to three times. Plants as old as eight years can be planted successfully without balls. Seed is placed in rills seven to twelve inches apart. Where soil is very weedy, large and strong transplants must be used. Planting in noles, on mounds or in furrows. The cleft spade is also permissible in planting yearlings. Trimming is not advisable, except to prevent formation of forks. Transplanting of germs, in June, is quite successful.

Elm: Seeds to be planted in summer (excepting Slippery Elms), just after ripening, in rich nurseries, and to receive very light cover of sand. Seed beds must be sprinkled, and the formation of a crust must be prevented. Seedlings cannot penetrate a layer of one-half an inch of dirt. Usually, transplants three to five years old are used. Fall planting is preferred. Elms stand trimming easily.

Maple: Drills three-fourth inches deep, one inch wide, eight inches apart. Transplanting takes place when seedlings are one or two years old. Seedlings grow rapidly. Fall planting is preferable. Planting in large holes is best, since Maple eannot form 
a compact root system. Sugar Maple planted four years old at Biltmore on abandoned fields did very well on Nortlı Slopes, in pure stands as well as mixed with White Pine. Maple is easily out-planted, and even yearlings or two year olds might be planted in the open on good soil. In swamps, Red and Soft Maple are preferable. Sugar Maple requires well drained soil.

Yellow Poplar: Very poor seeds, hence broadcast planting. Covering with spent sawdust, instead of dirt, seems advisable. Seedlings transplanted either as germs in first summer or when one year old. Very rapid growth in first and second year. Easily transplanted in holes on suitable soil. Seedlings can be taken in June and July from wood roads to the nurseries, with balls of . dirt. Abandoned fields at Biltmore, planted with four year olds did poorly except in northern depressions or in mixture with White Pine. Strong soil needed. Compact soil not unfavorable.

Catalpa: The favorite liansas prairie tree. Very high germinating percentage. Tery fast growth in first year. Rills one inch by one inch by twelve inches. Seedling plants one.year old are strong enongh for planting. Stump plants are preferable. At Biltmore the top shoot is often killed by frost; it should certainly be cut off after planting. Catalpa requires wheat soil in order to form proper bole, and does not answer in a cold climate. Spring planting in holes or furrows.

Walnuts: The planting of seealings is not permissible except where mice, squirrels and hogs are sure to get the nuts. Very long taps make planting difficult. Best soil needed. Small seedlings are choked out by weeds. Plants one to three years old to be used, and pure plantations to be avoided. Cover in the nurseries three inches, distance apart four tc ten inches.

Hickory: To be treated like Walnuts; during the first years, the stems remain very minute while a large tap root forms. Voles follow along the rows of plants and cut off the roots at a point abont one inch below ground. Loose, porous soil is needed.

Cherry: Planted in rills one-half inch deep and eight inches apart. Transplants two or three years old, transplanted when one year old are best for use in the open. Protection from rabbits pecling the stumps is required. Rapid growth in nurseries. Twig tips are usually killed by the first frost since the twigs grow during the whole summer and fall. Pruning required, Black Cherry does well on abandoned fields mixed with White Pine, Pine, Ash, Maple. 


\section{A IERICAN SYLVICULTURE}

Sassafras: Planting of sced in nurseries at Biltmore has been an entire failure. The seeds lived through the first summer but did not begin to sprout. Deep cover required, since cotyledons are kept underground. The removal of the flesh enwrapping the seed (by malting, etc.), is required before planting.

\section{Paragraph XXXVI. Raising and planting soft- wood seedlings.}

Yellow Pines: Seeds are covered two-fifths to three-fifths inches deep. Nursery soil to be pressed thoroughly before and after seed planting. Planting of yearlings (from 5,000 to 40,000 per acre) forms the rule. The roots of such yearlings are ten inches long. On sandy soil, cleft planting is universal (with planting dagger). On binding soil, ball plants one or two years old are best.

Recently some foresters recommend transplants two years old which more readily overeome the infantile diseases. No mound nor bunch planting. On very sandy soil Yellow Pines are planted deeper (up to first needles) than they stood in the nursery. A plantation ten years old should densely cover the ground.

Jack Pine (Pinus divaricata) does very well on the poorest sand. Tery rapid growth. Pinus rigida crawls on the ground during the first and second year, putting up a strong stem thereafter. Pinus sylvestris (Scotch Pine) is the cheapest that can be planted and the most successful species in the Adirondacks. At Biltmore it does exceedingly well on dry south slopes..

White Pine: Quite different from Yellow Pine is the ease with which it is transplanted. Seedlings one year old are very small and apt to suffer from leaves smothering them. Seedlings two years old have been planted at Biltmore on abandoned fields (in holes) very successfully. Transplants three and four years old are usually used. Owing to its greater shade bearing qualities White Pine may be used also for temporary underplanting. Seedlings suffer badly from fungi. White Pine is subject to damage from too-deep planting. In the Adirondacks, the best and strongest individuals form a second summer shoot, the buds of which are killed by early frost, so that no top shoot grows in the ensuing year. At Biltmore, the second shoot seems to be safe from frost.

Spruce: Nursery rills one inch wide, five inches apart. Transplanting distance usually four to six inches. Slow growth at first. Smallest size that may be used are seedlings two years old. Ball 


\section{THE ART OF THE SECOND GROIVTH}

planting best, bunch planting frequent in mountains. Transplants three to five years old are preferable. Plant in holes, never in clefts. Badly affected by deep planting. Spring planting forms the rule except in high mountains. High atmospheric moisture is a prerequisite for Spruce. Do not trim. Number of plants per acre from 1,500 transplants to 10,000 seedlings. Picea excelsa might replace $P$. rubens (the former being cheaper), if the resistance to snow-breaks shown by rubens were equalled by excelsa. Plantations twelve years old should fully cover the ground.

Firs: Seed should be planted in fall. Rills close, say four inches; cover, one-half inch. Early growth very slow; lath screens very essential, owing to sensitiveness of youngsters to heat and cold. Transplants five years old are best. Planting on open ground is dangerous; underplanting is very advisable. Species most planted are Abies pectinata, balsamea, concolor.

Larch or Tamarack: The European and Japanese Larch are scattering species, doing badly in pure stands. Growth in early youth is rapid. Seedlings two years old and transplants three years old are preferred for forest planting. The distance of the rills, and the transplanting distance must be comparatively wide. Seedlings might be eleft planted; but hole planting forms the rule. Fall planting necessary. Larch permits of heavy trimming. Nulch seeds for one week before planting. European Larch does well at Biltmore and in the Adirondacks.

Hemlock: Grows very slowly in youth. Seedbeds require heavy sheltering (umder cloth screens). Transplant the two year olds, and plant the five year olds under cover in the woods.

Douglas Fir: Seeds are still expensive; hence transplants four years old are usual, though seedlings two years old are certain of success. Hot-house treatment of seeds secures early and simultaneous sprouting. Plant seedlings in open ground, not under cover. Plantations made near London, England, lose the long top shoots by sea winds; in the Adirondacks; they suffer from frost; at Biltmore, the growth is strikingly poor, possibly due to the defieiency in atmospheric humidity. Plants fourteen years old are hardly chest high; plants eleven years old only knee high. In all eases the Washington variety is used. Varietas glauca, of Colorado, grows slowly, and is more hardy.

Red Cedar (Juniperus virginiana): Seed lies dormant for one summer. Seedlings two years old are ready for planting. High lath screens in nurseries advisable (Green). Very slow growth. Shade bearing. 


\section{A MERICAN SYLVICULTURE}

Lawson's Cypress: Stands intense shade, resists frosts, suffers from fungi; is well adapted to underplanting.

\section{Paragraph XXXVII. Results of planting experi- ments with American hardwoods.}

For many years, the govermmental forestry bureaus of the Gexman States have been examining the merits of some leading American tree species.

Locust and White Pine have been planted so extensively that they are considered as "naturalized forest citizens."

In a number of instances, the European views fail to tally with the results of American investigations made with reference to the sylvies of our leading species.

A. Fraxinus americana: Requirements as in excelsa; stands inundation better. Germination in first spring. Plant seeds in fall, or else in early spring after three days soaking. One year old, one foot high.

Use transplants two or three rears old.

Root is a tap-root with many side roots.

Mayr does not advocate its propagation anywhere in Germany.

B. Catalpa speciosa: Suffers from short summers, often freezing down to ground. Hence frequently spreading growth.

Seeds of high germinating percentage.

Use either seedlings or transplants two years old.

Light demanding, but fond of side shade.

Mice peel at point of differentiation; all game is fond of Catalpa.

C. Juglans nigra: Mild, fresh soil required, and long warm summers.

When one year old, strong tap-roots over one foot long; root fibres at end of tap-root tip.

When two years old, the tap-root is over two and one-quarter feet long.

Height growth: 5 years old, 5 feet.

10 years old, 13 feet.

20 years old, 35 feet.

Decidedly light demanding; fond of side shade in early youth.

Yellow Pine shelter wood is very good: More shade prevents lignification. In close stands, it is free from branches. 
Nuts spronting late (being dried out) cause shoots to be killed by early frost: Hence pre-germination advisable.

Frost hard in sapling stage.

No game or mice enemies.

Plant nuts or yearlings on well-plowed ground, and cultivate. Plant close together, so as to aroid branchiness. Prune none but lignified branches, owing to heavy pith column.

D. Prunus serotina: Modest, provided soil is moist.

Light demanding, but does well under slight Pine cover.

Roots many tapped, strong.

Height growth better than that of any European hardwood, save Ash.

5 year's old, 6 feet high.

10 year's old, 13 feet high.

15 years old, 22 feet high.

Proof against all effects of frost.

Rabbits ent and peel (also mice) young plants.

Seed-beds: Plant in fall, to avoid lying over, or else soak in water for three days previous to planting in spring.

Use transplants three years old; plant close, to avoid side branches.

E. Acer saccharum: Fresh, sandy loam, or fresh sand; forming stool-shoots on dry soil, and no stem.

Growth quick; light demanding; strong root system.

Forms forks frequently fifteen feet above ground.

Height 35 feet, when twenty years old.

Most frost hard of all Maple species. Game and rabbits (?) despise it.

Seeds mature in June, and can be planted at once, but are just as well preserved and planted in spring.

Use seedlings two years old, or transplants, four years old.

F. Acer negundo: Requires strong soil; does not do on dry soil. Growth very quick to start with, in two years up to six feet, in twenty years fifty feet.

Development of low, branchy crown.

Light demanding, frost proof.

U'se seedlings one year old.

Damaged by game and rabbits.

G. Acer saccharinum: Requires strong soil; not clay.

Growth slower than in other Maples, up to fifth year; 20 years old thirty-five feet high.

Apt to form forks. 


\section{A MERICAN S Y L I ULTURE}

Sensitive against frost and drought; requires shade; does best when used for underplanting.

Use transplanted small saplings.

Aroid planting on open ground.

Mayr recommends it for sugar orchards, not for timber production.

H. Betula lenta: Aroids wet frost dells and poor dry soil; forms tap-root on sand and flat-root on clay.

Height in five years five feet; in twenty years thirty-six feet.

Growth bushy to start with, but soon straight, ereet and free from branches.

Decidedly light demanding, but fond of side shade.

No more frost-proof than Beech. Late and early frost damages it, especially on wet clay.

Game, rabbits and mice are very dangerous.

Sced-bed should not be dug over.-Peel-off the top cover of grass and weeds on humose sand, hoe the soil and then use roller. Plant broadcast, one pound for two square poles; cover by sifting onetwenty-fifth inch of sand on the seeds and roll again with roller; keep Pine branches on the seed-bed until after germination.

Use tall transplants for planting in the open, owing to animal dangers.

Red Birch is said to do well when planted with Pine on abandoned fields, or when planted with Beech naturally regenerated.

I. Hickories: All hickories require strong, deep fresh, soil. Not on clay.

Pignut is satisfied with more sand, and Mockermut with more elay.

Butternut requires water, more than the others, and stands inundation.

All hickories require hot summers but stand severe winters; continental climate is better suited than sea climate.

Tap-root of yearling one foot long; of two year old plant one and three-quarter feet; hence transplanting after two years very difficult.

Height growth begins in the case of Hicoria ovata to set in from sixth year, and is good then.

Age 5 years, average heignt 2.4 feet.

Age 10 years, average height 7 feet.

Age 15 years, average height 13 feet.

Age 20 years, average height 20 feet.

Buds open late but shoot is quickly made. 
Nuts germinate slowly; hence malting or better repeated sprinkling with liquid manme advisable; many nuts lie over, even for two years. Nuts thoroughly dried lose germinating power.

Malting or "pre-germination" advisable.

In the case of Hickory and Walnut, the following recipe for pre-germination is given:

"Make a ditch three feet deep and wide; put nuts in the ditch to a depth of one foot; fill ditch with water up to top of nuts; then add a slight cover of straw; then dirt; then horse manure.

"In this ditch the nuts are kept until planting time; the nuts will germinate a few weeks after planting (in May)."

Plant seedlings one or two years old, or else nuts, on plowed grome. Cultivating advisable.

Late frost is avoided by the late formation of shoots. Early frosts are bad, if seedlings did not have time to lignify owing to late germination.

Avoid planting on open ground; shade is endured readily for a number of years. Straggling plantations often develop after natural or artificial reinforcing with other species.

Young plants suffer from mice. Damaged seedlings should be coppiced down.

In Hicoria minima, growth is quicker to begin with than in Shagbark.

At twenty years, however, Shagbark catches up.

Wood much poorer than in Shagbark (more brittle).

Hicoria glabra is more modest as to soil than Shagbark Hickory, and more sensitive as to frost (?).

Hicoria alba is more sensitive than Shagbark; same rate of growth; does well in the Westerwald, badly in river valleys.

\section{Paragraph XXXVIII. Results of planting ex- periments with American softwoods.}

A. Pinus divaricata: Very modest. Stands frost and drought and does not suffer from Hysterium.

Root system tap-rooted, many fibred.

Height growth very rapid, several shoots per summer.

2 years old, 8 inches high.

5 years old, 5 feet high.

8 years old, 10 feet high.

Game and hares handicap it; still there is strong reproductive power. 
Seed one-half pound per square pole; seed has $60 \%$ germination; cones contain fertile seeds from sixth year on.

Use yearlings or transplants two to three years old for the very poorest soil.

B. Pinus ponderosa: Fails absolutely in Germany, probably owing to insufticient summer heat.

C. Pinus rigida: Very modest; does well in salty swamps; suffers badly from snow-pressure.

When 5 years old, 7 feet high.

When 20 years old, 32 feet high.

Growth is very rapid, but from twelve years on P. sylvestris eatehes up and then keeps ahead.

Diameter growth better than in sylvestris, too.

Strong reproductive power after damage by inseets, game, fire.

Very light demanding.

Cones seed-bearing from twelftll year on.

More proof against late frost, more sensitive for early frost than sylvestris.

Less shedding of needles due to Hysterium; more danger from game.

Use yearlings, or transplants two years old.

D. Picea engelmanni: likes strong but not wet soil-it is winter frost hard; but suffers slightly from late frosts.

Root system deep, many fibred; not flat.

Dislikes top shade.

Yearling only one to two inches high; two years old four inches high; five years old one foot high.

Height growth always siow, hence easily outgrown, and pure stands required.

T'se transplants, five years old.

E. Picea parrayana: Very frost proof, more so than any other Spruee.

Stands wet soil; not exacting.

No top shade.

Root system eompact, fine fibred.

Slow early growth, as in Engelmamn's spruce.

Plantations ten years cld average but one and three-quarter feet in height.

Animal proof.

F. Picea sitchensis: Requires moist soil and moist air.

Heat requirements as in $P$. excelsa. 
Soil requirements less than in P. excelsa, growing both on sand and on elay. Not in stagnating moisture, but stands inundation well.

Does well on seashore and at high altitudes.

Height growth at first very slow; from fifth year on better than in excelsa.

Short branches, slowly dropped; close stand required, fond of forking.

No top shade. Side shade welcome but not required.

Frost and drought not dangerous except during first and second year.

Game does not bother it.

Seed-beds of mild, rich soil to strengthen weak seedlings.

Use strong transplants, five years old.

G. Abies amabilis: Plants five years old are still subject to damage by direct insolation and by late frosts.

Rate of growth as in A. pectinata.

H. Abies concolor: Spring shoots formed late; resists frosts and any other elimatic attacks well.

Not exacting as to soil, dioing well on Seoteh Pine soil of second quality, provided that it be fresh.

Tap-root formed in second year.

Height growth in early youth better than in any other Fir; plants eight years old have average height of three feet.

On good soil, even Spruce is outgrown by it.

Seedlings two years old are fit for planting; they suffer when planted too deep.

Seed-bed treatment as in A. pectinata.

I. Abies grandis: Treatment as in pectinata, which it exceeds in height growth. Soil requirements are the same.

J. Abies nobilis: Frost firm in winter, even unprotected. Late spring shoots help it to escape late frosts.

Stands dry soil; from fifth year on, more light demanding. Forms strong tap-root, and sometimes several whirls of branches per annum. Plantation seven years old is three and one-half feet high.

Plant seedlings two years old, or transplants four years old.

K. Pseudotsuga taxifolia: Suitable to any climate, frost proof.

Soil should not be poorer than third-class Pine soil; no dunes; no swamps. 
Root is a tap-root on l'ose soil, is flat on shallow or binding soil, and shows great adaptability.

Height growth marvelous:

Age 5 years height 1.7 feet.

Age 10 years height 12 feet.

Age 15 years height 29 feet.

Age 20 years height 45 feet.

Age 23 years height 53 feet.

Diameter, twenty-three years old, from three inches to ten inches, arerage seven inches; number of trees per acre 350 .

Close stand required to clear from branelies.

Light and heat demands as in Picea excelsa.

Snow and sleet throw it over, or break top shoot, the latter loss being quickly replaced by side shoot taking lead.

Game is a bad enemy.

U'se transplants three to four years old.

L. Chamaecyparis lawsoniana: Does splendidly in Germany especially in the Eifel Mountains at 1,500 feet elevation.

Frost-proof; but sensitive during drought.

Exacting like Beech, fond of limestone.

Flat-rooted; suffers from snow.

Shade bearing in early youth; fond of partial shade later on; always fond of side shade.

Slow in clearing itself from side branches; forms very close stands.

Very slow growth to start with; one year one inch high; two years four inches high; ten rears eight inches high.

Plant seed-beds broadeast, and cover them completely. Use transplants four to five years old. Do not plant too deep.

Game are very bad; wood mice peel the stump, or ent the roots.

Suffers but little from late frost because of late sprouting; more subject to harm by winter frost.

M. Juniperus virginiana: Aroid poor or wet soil.

Seeds lie over; seedlings one to two years old are very small and tender. Side shade always liked. Suffers from weeds and grass. Red deer and Roe deer bite and beat it.

Seeds kept in ditches over summer are planted in fall.

Use yearlings and plant in holes.

N. Thuja plicata: Desires good, fresh soil, and avoids swamps.

Top shade or side shade is well liked; do not plant in open ground. 
Deep root system.

Height growth slow to begin with, rapid from seventh year on: Age 1 year; height 1 inch.

Age 5 years; height $4 \frac{1}{2}$ feet.

Age 10 years; height 8 feet.

Age 15 years; height 15 feet.

Age 20 years; height 23 feet.

Slow cleaning of bole; very dense thickets required.

Seed bearing from fifteenth year on.

Subject to damage by frost and drought during first years.

Game does not attack it; mice destroy young seedlings.

Seeds are planted broadeast; slightly covered with. dirt; sheltered by lath sẹreens.

Strong seedlings three years old (not transplants) are used since the root system is comparatively small, whilst the stem system is comparatively large.

O. Tsuga heterophylla: Requires strong soil; demands side shade, but hates top shade. Cannot stand open situations.

Root is a strong tap-root.

Height growth good from third year on.

Tips of the top-shoot are frequently killed by first frost, without any apparent permanent damage.

Use seedlings three years old, rased by broadcast sowing.

Shelter seed-beds well. Avoid deep planting.

Mayr prefers heterophylla to canadensis for planting in Germany.

\section{- Paragraph XXXIX. Difficulties of natural seed regeneration.}

Theoretical foresters frequently make the statement that the axe is the best sylvicultural tool inasmuch as its proper use secures a good regeneration free of charge. This statement is misleading. It is true that the density of the stand of the second growth obtainable from natural regeneration is frequently better than that obtained from artificial planting. On the other hand, a good stand cannot be obtained but under favorable conditions and at a great increase of the logging expenses. While the cash expense of natural reseeding might be slight, the actual expense consisting in lessened receipts frequently exceeds the expenses of artificial planting. In the primeval woods, additional difficulties of seed regeneration induced by man lie in the following points: 


\section{A. Over-aged trees have poor seeds.}

B. Interference with the leaf canopy overhead at once invites danger from fire, increased by the debris on the ground, and by the impossibility of battling against fires in the underbrush.

C. In the primeval forest, the age classes are usually mixed in an irregular manmer; uniform measures for reproduction are therefore ont of the question. The forester cannot generalize; he must individualize,-a very expensive procedure in the face of low stumpage values.

D. The virgin forest usually contains a mixture of species; the best ones alone are remorable; the weeds and the worthless species are left on the ground; and from this fact arise additional difficulties in the propagation of the most valuable kinds. To this must be added the difficulty of properly guaging the light and the shade according to the individualities of the species mixed.

E. The lack of a permanent system of transportation in America necessitates the operations to extend at one stroke over large areas, whilst natural seed regeneration requires the gradual removal of mother trees from small and restricted areas in imitation of nature's own way of proceeding.

As a matter of fact, the lack of permanent means of transportation in primeval woods is the most serious obstacle to the use of regeneration from self-sown seed by a forester conscious of his aim and its effect.

F. Natural seed regeneration requires cutting, according to the occurrence of seed years and according to the development and the requirements of the young growtl. The axe therefore must be independent from the fluctuations of market or mill requirements, - an impossible demand in the United States at the present time.

The term "natural seed regeneration" does not preclude the use of artificial help to increase the chances of regeneration. The term merely implies "seeding," or scattering of seed, in the main unaided by man. Man, however, may carefully prepare the seedbed, by plowing or loeing or digging, or may carefully press the seeds naturally fallen into the soil; and may protect the seed and the seedlings, at great pains, against external dangers.

Little help is given, where soil and stumpage are, and promise to remain, of small value. 


\section{THE ART OF THE SECOND GROWTH}

Under the reversed conditions, the expense incurred for natural regeneration often exceeds that required for artificial regeneration.

In innumerable cases, natural and artificial regeneration are locally and irregularly combined.

It might be claimed that the forest has secured its own regeneration through many millenia, and that it will continue to do so unaided by human activity. Why then, it might be asked, is it necessary or advisable to now offer costly assistance in order to secure a natural reseeding of and in a lumbered tract of woodland? - There cannot be any doubt that nature, barring bad conflagrations or heavy pasturage, will start and develop after lumbering some kind of a second growth of forest. As a matter of fact, it is usually at hand, previous to lumbering, in an embryonic or incomplete state waiting for the chance to shoot ahead after the removal of the older trees. This ready nucleus, however, consists as a rule of inferior or worthless species; of specimens erippled by fire, by the fall (accidental or otherwise) of nearby trees, by the logger's axe or foot, by passing teams and loads, ete. In addition, many members of that nucleus will die when suddenly bereaved of the shelter (against drought, cold, hail, etc.), previously exercised by the old trees now removed.

It must be remembered that a crop of weeds usually follows in the field after the harvest of valuable wheat; in the forest after the harvest of valuable timber.

Such "weeds" are unable to secure for the owner of the land a sufficient rate of interest on the vahe of the soil and an adequate reimbursement of the taxes due on the soil.

Another point worthy of attention lies in the poor chances. which a grain of seed stands, in nature's economy, to develop into a seedling, sapling, pole and tree. The probability is that but one grain of seed-out of millions of grains-produced by an individual tree during its lifetime sncceeds in reaching tree size, replacing its progenitor on the forest floor. The ecologic incidents bringing about this result are far from being clearly understood. Still, it must be the sylviculturist's aim to provide for these incidents, if he desires to replace the old crop, removed at an unnatural rate of rapidity, at an equally fast rate by an offspring resulting from self-sown seed.

If the forester were satisfied to merely remove nature's moribunds, then he might get along with a purely natural regeneration, entirely unaided by human skill. 
As soon, however, as his axe creates in the forest an unnatural rate of death, the forester is compelled to also secure, by intelligent means, a supernatural rate of birth.

Human aid to natural regeneration should be denied where:

a. The danger from forest fire is such as to render investments in a second growth very unsafe.

b. An outlay incurred for protection from fire is not apt to be refunded with interest by the value of the second growth.

That much aid and that much money should be, in all other cases, spent for the purpose of regeneration as promises, in the owner's mind and according to the forester's forecast, the lighest relative revenue on the investments made.

The owner of timberland, intending to secure a second growth where he removes the first, might set aside a certain percentage of the net receipts obtained from stumpage annually cut,-say ten per cent,-for the purpose of raising, by one means or another, the second growth desired by him. Continuity of action is the mainspring of forest conservation. Sylviculture cannot be practised off and on. Regular appropriations are required to secure regular results.

Sylviculture and finance are continuously at loggerheads. From the business standpoint, however, that Sylviculture is certainly best which proves lastingly most remunerative.

Where and as long as the prospective value of seedlings is small, none but a small expense can be reasonably incurred on behalf of their propagation.

Again, seedlings are more endangered by fire than trees. Where, and as long as the danger from fire prevails in the forests of the United States, investments made for raising seedlings are so risky as to be inadvisable.

\section{Paragraph XL. Age of trees fit for natural seed regeneration (enesar).}

The age of perfect puberty depends on species, density of stand, quality of soil and climatic conditions. Generally speaking, it lies about the eightieth year of the trees.

Birch, Alder, Larch and Yellow Pines may be seed-regenerated from their twenty-fifth to thirtieth year on; Oaks, Beeches and Firs from their sixtieth to eightieth year on. Trees of very old age, say over 200 years old, often defy natural regeneration if soccurring in pure, even-aged stands. 


\section{Paragraph XLI. Types of natural seed regen- eration (enesar).}

A fixed method is applicable in the arts only where a fixed set of conditions exists. Fixed and regular forms exist in primeval woods but rarely. Hence the impossibility, from a sylvicultural standpoint, to adopt any fixed European "method" of seed regeneration for direct application in American practice.

There might be distinguished, nevertheless, within all woods - on the globe, certain distinct and characteristic "tricks" or aggregates of characteristic qualities and influences typical for the spot on which they are found, by which Nature secures, with or without Man's co-operation, a local rejuvenescence of the forest. These tricks-not methods or systems-had best be called "types of regeneration:" Typical conditions are used to produce typical effects.

The word "enesar" is used in lieu of n. s. r., or in lieu of "natural seed regeneration."

The types of enesar, like the types of animal breeds, or of machines, may be scrutinized from various viewpoints. We might differentiate them:

\section{A. According to the relative position of old and new growth:}

I. The young growth develops underneath the old growth:

a. Whilst the old growth is left intact (natural seed regeneration by advance growth), or

b. Whilst the old growth is gradually reduced (natural seed regeneration under shelter woods).

II. The young growth develops at the side of the old growth (natural seed regeneration from adjoining timber).

\section{B. According to the size of the units of regeneration, which may be:}

I. Compartments, i. e., a cove, a slope, a top or a coherent part thereof, comprising from ten to one hundred acres.

II. Strips, i. e., figures of a more or less rectangular form, in which the length is a multiple of the breadth, the latter not exceeding 500 feet.

III. Groups, i. e., aggregates of growth of a more or less circular form, covering 0.1 to 4 acres.

IV. Patches, i. e., areas covered by the crown of an individual tree, about 0.01 acre in extent.

The figures are meant to illustrate, and are not meant to define (in this paragraph as well as in the following fifteen paragraphs). 


\section{According to the degree in which the soil and the youngest seedlings are directly exposed to the sky:}

I. Regeneration without exposure,-by advance growth.

II. Regeneration with short, slight, partial exposure,-under shelterwood. timber.

III. Regeneration with entire, heavy exposure,-from adjoining

D. According to the timing of lumbering and of reseeding:

I. Lumbering precedes reseeding,-natural seed regeneration on clearings, namely:

a. On uniformly cleared compartments (cleared compartment type) ;

b. On cleared strips (cleared strip type);

c. On cleared groups (cleared group type) ;

d. On cleared selected patches (cleared selection type).

II. Lumbering coincides with reseeding,-natural seed regeneration under shelterwood, namely:

a. On uniformly sheltered compartments (shelterwood compartment type);

b. On sheltered strips (shelterwood strip type);

c. On sheltered groups (shelterwood group type);

d. On sheltered selected patches (shelterwood selection type).

III. Lumbering follows reseeding,-natural seed regeneration by advance growth, namely:

a. With advance growth all over a compartment (advance growth compartment type);

b. With advance growth in strips (advance growth strip type);

e. With advance growth in groups (advance growth group type);

d. With advance growth in selected patehes (advance growth selection type).

E. According to the participation of ligneous weeds (bushes, seedlings, saplings, poles and trees of a negative value) in the regeneration:

Totally successful seed regeneration;

Groupwise successful seed regeneration;

Patchwise successful seed regeneration;

Individually successful seed regeneration;

Unsuccessful seed regeneration.

In America, it will be frequently adrisable for the forester to 
merely work toward a "groupwise" or "patchwise" successful seed regeneration.

F. According to the number and according to the distribution of standards left in the regeneration "area": Natural seed regeneration:

a. With standards systematically left all over the compartments;

b. With standards left in strips;

c. With standards left in groups;

d. With isolated scattering standards.

The "compartment" types had better be called "uniform" types; the "selection" types had better be termed "patch" types. Still the terms "Shelterwood compartment system" and "shelterwood selection system" having become staudard terms of forestal terminology, it seems unwise to throw them aside.

A number of "pure types" may be, and usually are, combined into "bastard types." Of course, only types more closely related allow of bastardizing.

Bastard types frequently found in the old country are:

"Advance growth selection" and "shelterwood group" type;

"Advance growth group" and "shelterwood compartment" type;

"Shelterwood group" and "shelterwood strip" type;

"Cleared strip" and "advance growth strip" type;

"Cleared group" and "shelterwood group" type;

"Cleared selection" and "shelterwood group" type.

Modern forestry abroad begins to despise methodical rules, gradually returning to nature with her irregularities. Pure, abstract types of seed regeneration are more and more discarded.

The selection of a method or a combination of methods depends entirely upon the composition of the growing stock found; on local dangers; on local means of transportation; on value of stumpage and prospective value of seedlings.

Where all age classes are mixed irregularly, individual selection is, ceteris paribus, indicated.

Where the age classes or the species appear in groups, the group method is or may be advisable.

In woods simultaneously maturing, the uniform type may recommend itself.

G. H. S. Graves, in "The principles of handling woodlands" distinguishes between the following "systems"-he does not use the term type-of natural seed regeneration: 
I. The selection system applicable to stands in which trees of all ages are represented.

\section{II. 'The clear-cutting system:}

a. Clear-cutting the whole stand (Schenck's cleared compartment type).

b. Clear-cutting up to $75-85 \%$ of the area, but leaving intact, in large blocks up to $25-15 \%$ respectively of the original stand.

c. Reserving scattered seed trees.

d. Reserving groups of seed trees.

e. Reserving thrifty standards.

f. Clear-cutting in strips (Schenck's cleared strip type).

g. Clear-cutting in patches (Schenck's eleared patch type).

\section{The shelterwood system:}

a. Cuttings distributed uniformly (Schenck's shelterwood compartment type).

b. Cutting in groups (Schenck's shelterwood group type).

c. Cutting in strips (Schenck's shelterwood strip type).

The systems (viz., types) enumerated under II. a., b., c., d., and e., cannot be considered to be a means by which the forest may be "systematically" reproduced.

The following paragraphs are arranged to conform with the view point given under "D."

\section{Paragraph XLII. Types in which lumbering pre- cedes $N$. S. R.}

Where lumbering precedes regeneration, the area lumbered must be reseeded from the borders of adjoining woods. With increasing size of the area cleared of timber, the rapidity, the certainty and the quality of regeneration rapidly decrease. The fact that such regeneration is possible on a large scale, is readily proven by object lessons in the primeval woods (Long Leaf Pine; Bald Cypress; Lodgepole I ine; Douglas Fir) as well as in second-growth forests (White Pine in Lake States; Yellow Pine in the south; Spruce in the Karpathian Mountains).

The chances for success depend on:

A. The species, which must have light or winged seeds readily carried about by the wind (many Pines, Spruces, Larches, Cottonwoods, Birches, Yellow Poplar), and which must not require, during their earliest stages of development, the presence of a shelterwood overhead. 


\section{THE ART OF THE SECOND GROIVTH}

B. The coincidence of the compass direction in which the clearing lies from the adjoining woods, with the direction of the wind preferably opening the cones and carrying the seed.

C. The local dangex from storm which might tear down, gradually at least, the adjoining seed trees.

D. The condition of the cleared soil and its quality as a ready seed-bed, influenced by the presence of weeds; by the decomposition of the humus; by the degree in which the mineral soil has been laid bare in the course of logging operations; by the grade of the slope.

E. Fires favorable or unfavorable; pasture favorable or unfavorable to regeneration, as the case may be.

F. The frequency of seed years, and the possibility of lumbering during a seed year.

G. The size, the form and the environments of the area cut over.

H. The possibility of preventing undesirable species (Gums, Black Jack Oak) and undesirable specimens, like lowbranched weed trees and spreading "wolves," from occupying the area to be regenerated, and the possibility of regenerating all, a few, or only one species.

According to the size of the clearing, we distinguish between:

The cleared compartment type (large areas cleared);

The cleared strip type (narrow belts cleared);

The cleared group type (fair sized groups cleared away);

The cleared selection type (small bunches of trees or merely single trees cut).

\section{Paragraph XLIII. The cleared compartment type.}

A. The area bared at one stroke by lumbering conprises between, say, ten and one hundred acres. If the width of the clearing is less than 500 feer, the "cleared strip" type is reached. If the acreage cleared is much in excess of 100 acres, the development of a second growth is very slow, very poor, very doubtful, so that the character of a sylvicultural type is lost. A number (say five) of seed years are required to restock the ground. The bordering woods, from which reseeding is expected, must not offer an unprotected front to the prevailing storm direction. 


\section{A MERICAN SYLVICULTURE}

The regeneration obtamed is, naturally, very heterogeneous and contains a great deal of misshapen advance growth as well as of weed growth.

Weeds trees left on the ground might be girdled if belonging to an undesirable species (Beech in Galizia).

A few seed trees might be left scatteringly (if wind firm) in groups or in strips, preferably elose to the roads, also doty specimens without any value.

An usher growth of Cottonwoods, Birches, Sumac, Locust, Sassafras, etc., frequently precedes the second growth desired on the ground.

Fires preceding the seeding, and immediately in the wake of logging, greatly enhance the success of Yellow Pines, Douglas Fir, etc. Yellow Poplar, on the other hand, is checked by the heavy growth of weeds following tires. Stock pasture is of adrantage, where it presses the seeds into the soil, and where it checks the weeds.

The clearing should comprise, if possible, only one side of a cove at a time or the lower part of a slope or the bottom of a cove, so as to allow of greater ease in reseeding.

B. Actual application: This type has been adopted, - not confessedly but actually-by the Austrian Government in dealing with the primeval woods of Galizia, consisting of Beech, Fir and Spruce.

The United States Forest Service has tried to adopt it in modified form under the name "single tree method" for the Minnesota National Forest and in the majority of its business-working plans (Sawyer and Austin; Weyerhäuser).

Thousands of acres of abandoned farm land all over the Eastern States have been reforested in this manner, usually in pines, frequently against the owner's will.

C. Advantages: The cleared compartment type shows the following advantages:

I. Greatest ease in lumbering.

II. Concentrated operations and concentrated supervisio.1.

III. Few permanent main links of transportation required.

IV. Smallest deviation from the old-time manner of destructive lnmbering.

V. Possibility of temporary use of the clearing for the production of field crops benefited by the fertilizing effect of the humus. 
VI. Ease of artificial reinforeing and possibility of soil preparation by plowing and by firing; of covering the seeds by pasturage.

\section{Disadvantages:}

I. Applicability to few species only.

II. Danger of partial or complete failure, especially in clearings covering 100 or mole acres, or in case of border trees unfavorably situated.

III. Danger from heavy fires where the soil and the humus is baked by the action of the sum, with heaps of debris left on the ground after wholesale logging.

IV. Second growth consists largely of wolves, and of spreading advance growth and of poles undesirably ramified. Expensive girdling or cutting of seed-bearing weed trees, belonging to a worthless species.

$\checkmark$. The annual expenses for protection from fire and for taxes are, to a degree, independent of the quality of the young growth. They are relatively high, and hence absurdly unbearable, if that growth is poor, straggling and very slow to develop, all of which is apt to be the case in this type of seed regeneration.

Thirty years after clearing, the average age of the young growth is not apt to exceed ten years.

Soil values exceeding ten dollars-so as to give a figure-per acre would make a second growth expensive when thus slowly produced.

YI. Groups of advance growth are almost sure to be destroyed or to be crippled by logging and by sudden change of environments (e. g., Maple and Beech in Michigan).

\section{Paragraph XLIV. The cleared strip type.}

A. The width of the cleared strip is from two to five times the length of the mother tree. When one belt is seeded successfully, another strip is ent into the timber alongside the first belt, and so on.

Soil work is not required, provided the strip is cleared in a seed year. Usually the soil is torn up sufficiently by the removal of a large number of logs snaked or rolled or shot along the strip and over the strip to the nearest road.

One seed vear is rarely sufficient to secure full regeneration of a strip. In the Alps, Pine regeneration takes from twelve to thirty years. On hardwood soil, the weeds are to be dreaded, preeminently so on fertile ground after fires. 
It is wise to leave a few wind-firm mother trees scattered over the strip, notably immature specimens of the most desirable species. Less desirable species on the nearby border might be girdled or removed by extending the removal of that species into the bordering forest. In addition, valuable hypermature trees might be withdrawn from the nearby forest.

The cleared strip type does not require a permanent system of transportation of great intricacy, the strips themselves forming the main lines of transportation. The narrow edge of the strip merely is touched, on the valley side, by a road. According to the grade of the strip, sleighs, cables, chutes, donkey engines, etc., are used to deliver the $\log$ s to the road.

At the beginning of operations, the first strip should be made in sheltered localities so as to allow the forest adjoining leewards to remain unharmed by storm.

The strips proceed windwards gradually, the next being cleared when regeneration in the preceding strip is fully secured.

North of the equator, the cuttings should proceed from the North to the South (Professor WVagner's discovery), since enesar is most successful on the north side of the forest. In case of species subject to windfall, the progress of the axe should be directed from N.N.E. to S.S.WV.

The langer from insects and fungi is small. The danger from fire, to begin with, is great, although not so great as in large clearings to which the wind and sun are freely admitted. Later on the even-aged character of the strip will help to check fires.

Nothing prevents the owner from reinforeing the strip artificially if he thinks fit. Healthy groups of advance growth, formed by desirable species in the belt at the time of logging, might be carefully husbanded. Natural regeneration will set in as well at the side of the belt underneath the bordering mother trees. "Regeneration runs into the old woods." This is a very desirable state of affairs allowing, in the next belts, regeneration to start in advance of cutting. (Bastardizing the eleared strip type with the advance growth strip type.)

B. Actual application: This type of regeneration is locally used in the Tyrolian and Austrian Alps, for Spruce, Larch, Pine. The form of the strips need not be rectangular. It depends on maturity of growth, configuration of soil, danger from storm. The type seems well adapted to present American conditions, requiring, of course, local modifications or bastardations, governed by species 
and market. Its applicability, however, rests on the existence of some permanent chief arteries of transportation.

At Biltmore, the type is applied, in modified form, for the reproduction of Yellow Poplar and Yellow Pine.

\section{Advantages of the cleared strip type:}

I. Applicability to many species, to many conditions and to many localities.

II. Concentration of logging operations; sylvicultural help possible; cheap logging by donkey engines, chutes, snaking, etc.

III. Many points of attack, at which the season's cut might be obtained, are at the disposal of the forester, if he so desires. Hence great freedom of action.

IV. Comparative safety of the old woods from storm; of the young growth from fire, drought, frost, insects, etc.

D. Disadvantages of the cleared strip type:

I. If the seeding of the strip is not effected soon after clearing, the soil is baked by the sun, weeds are started and the ecological conditions are affected in a manner barring the success of seed regeneration and necessitating artificial help.

II. Border trees are exposed to sun scald.

III. Animals frequent the strips and spoil the young growth.

IV. The soil of the strip-especially of the first strip in a series-is rarely "in heat," certainly not over the entire strip, so that the seeds falling upon it have a poor chance of success. This is the case, preeminently, in the humid mountains where a heavy layer of raw humus covers the ground. A large number of years will often elapse, before the next adjoining strip can be taken in hand.

$V$. The strips should be cut where the timber is most mature at the time,-and not in a succession merely dependent on the condition of the young growth and on the necessity of proceeding against the prevailing storm direction.

\section{Paragraph XLV. The cleared group type.}

A. The groups cut comprise from 0.1 acre to four acres. The form is roundish, oval, square, etc., as the case may be, usually coinciding with a geological feature, e. g., a dell, a spur, a springhead.

The incentive for group-cutting lies either in the simultaneous maturity of the trees stocking on it, or in the desire to obtain conditions particularly favorable to the reproduction of one of the 
species appearing in the old timber; or the group, previously stocked with an undesirable species, is to be seeded by a better kind.

B. Actual application: This type has never played an important role in connection with natural seed regeneration. Sylviculturally it seems well adapted to Yellow Poplar, Long Leaf Pine, Lodgepole P'ine, White Pine, also to Hickory, Hard Maple and Oak.

Where the groups have the shape of long tongues, running parallel at regular intervals, they are termed "coulisses." The coulisses are usually meant for the regeneration of more lightdemanding species; the "benches" separating the coulisses for the regeneration of more shade-bearing species.

In Germany, the space formerly occupied by a cleared group is termed a "hole." Such holes are made frequently by storm, or by snow and sleet. Where the gromps, after reseeding, are gradually enlarged, the cleared group-type is bastardized with the shelterwood group type.

C. Advantages: The soil of the group, thanks to a sufficient amount of side shade, retains its freshness and porosity. It is sheltered from severe winds and severe heat. Species too sensitive for reproduction in larger clearings or strips can be raised in groups. Where the age classes appear in bunches, each bunch can be harvested at its proper age of maturity. No harm or little harm is done to young growth durmg the logging season.

\section{Disadvantages:}

I. Operations are scattering.

II. Intricate system of permanent roads required.

III. Gromps surrounded by tall timber frequently act as "frostholes" where young growth suffers badly from early frosts and late frosts in elear nights.

IV. Thin barked trees surrounding the group, and notably those standing at its northeasterly margin, suffer from sun seald; flatrooted trees suffer from storm.

\section{Paragraph XLVI. The cleared selection type.}

A. In this type, individual trees considered mature are selected for removal, either absolutely singly, or in very small patches formed by neighboring trees.

The elearings made are so small that only shade-bearing species will regenerate thereon, unless the soil be particularly strong. 


\section{THE ART OF THE SECOND GROWTH}

The cut is so scattering, that the soil is not sufficiently "plowed" by the loggers. Hence it will not act as a ready seed-bed (excepting the logging roads).

In mixed woods composed of many species, only the most valuable kind is usually withdrawn, and the small gaps made are occupied by shade-bearing and often less valuable species.

Beneath hypermature trees, the soil has frequently hardened and defies any attempt of seedlings to establish themselves after logging.

The cleared selection type is almost invariably bastardized with the shelterwood selection type and with the advance growth selection type.

\section{B. Actual application:}

In the tropies, Teak, Mahogany, Ebony, etc., are cut by selection, frequently regardless of the effect which logging will have on regeneration.

In Europe, the type is found in the Fir forests owned by farmers; in parks; in protective forests at the headwaters of rivers; on very steep slopes dotted with Larch, in the Tyrol.

In America, Yellow Poplar, WaInut, Cherry, White Oak, etc., are cut by way of individual selection,- but with no regard to reproduction. Also White Pine in the Spruce and Fir woods of the Adirondacks (also in the luardwood forests of Michigan) where it never succeeds, withdrawn alone, to reproduce its kind.

\section{Advantages :}

I. The water-storing power of the soil is generally well preserved under this type.

II. The second growth is never endangered by snow or drought or frost or sleet; the old trees remaining do not suffer from storm or sun scald.

III. Small wood lots may yield a steady annual supply of timber or wood under this type.

IV. The type is well adapted to parks.

\section{Disadvantages :}

I. The operations are very scattering. Indeed, they cover continuously the entire forest or a large percentage thereof. Difficulty of supervision. Destruction of small trees unavoidable on slopes.

II. An intricate system of permanent roads is required, since the axe returns every few years to the same compartment. If the intervals of years are long-say from ten to twenty years-the 
type is bastardized with the cleared group type or with the shelterwood group type.

III. The type as a means of regeneration, in its purity, is possible only where

a. The compartments contain a mixture of all age classes, with the hypermature classes not too badly prevailing;

b. The species to be regenerated is an intense shade-bearer;

c. The soil is strong enough to allow light-demanding seedlings a chance at surviving a long period of partial suppression.

IV. The species removed-presumably the most valuable species - has its prospects of propagating reduced, struggling against competing species, the number of its seed trees being relatively decreased.

V. Small chance for reinforcing.

VI. Impossibility of protection against fires under headway.

\section{Paragraph XLVII. Types in which lumbering coincides with $\mathbf{N}$. S. R.}

In these types of natural seed regeneration-so-called shelterwood types-lumbering and reseeding go hand in hand, both progressing seriatim, slowly, cautiously. In the pure types, no tree is removed, unless the removal has a distinct bearing-or is expected to have it-on the production of a progeny or on its further development. Seedlings less than five years old usually stand within a few yards of their mothers. This distance is gradually increasedin the course of up to fifty years-until the youngsters do not require any more, or rather despise, the benefit of the parents' presence.

Lumbering operations are carried on-in one and the same limited lot-during a number of years.

Where the mother trees are very rapidly removed, after reseeding, from the proximity of the youngsters, the shelterwood types approach the types of cleared compartments, eleared strips, etc.

Where the mother trees are very slowly removed, after reseeding, from the proximity of the youngster, the shelterwood types approach, or bastardize with, the advance growth types.

\section{A. The chances for success depend on:}

I. Sylvicultural talents of the forester in charge and of his staff, also on the size of the ranges. 
II. Frequency of seed years and time allowed for the entire operations.

III. Shade-bearing character of youngsters and firmness of parents.

IV. Existence of a permanent system of transportation.

V. Configuration.

VI. Danger from storm, sleet, fire, animals, etc., locally existing.

VII. Size of timber, value of timber, percentage of debris and waste.

VIII. Marketability of all species or of a few, even of one species only.

B. According to the manner in which the forester selects the nuclei for reseeding, we distinguish the following types:

I. Uniform type, or pure shelterwood compartment type, where the nuclei are geometrically and regularly distributed over the entirety of a large area (say over twenty to two hundred acres), the nuclei of the entire area being kept, during the entire progress of regeneration, in or about in the same uniform stage of development.

II. Shelterwood strip type, where the nuclei proceed, like advancing skirmishers, in regular military order either from the leeward side to the windward side of a compartment (cove, slope, etc.), or else from the North towards the South (WVagner). The nuclei to the leeward viz., northward are kept in a more advanced stage of growth than those to the windward viz., southward.

III. Shelterwood group type, where the nuclei are carefully selected, irrespective of geometrical arrangements, merely on the basis of the fitness of the individual spot to act as a seed-bed. The groups are gradually enlarged, increasing in circumference like waves caused by stones thrown in the water.

IV. Shelterwood selection type, where the most mature individuals are everywhere in all compartments and continuously selected for removal, individually or in small patches, with a view to. the simultaneous reproduction of the species removed by seeds left on such patches. The patch does not form a nucleus to be enlarged; it is to be retained for a long time in its original size.

In primeval nature, the shelter, or else the soil conditions created by a sheltering superstruction for the benefit of the understructure, are secured frequently in connection with a change of species. The understructure requires a fostermother, rather than a 
mother, for its best development. Sprnce nuder Fire Cherry, White line under Cottonwood, Engelmams Spruce under Aspen are examples for this phenomenon.

\section{Paragraph XLVIII. The shelterwood compart- ment type of natural seed regeneration.}

\section{A. This type is characterized by the uniform manner,} in which lumbering and regeneration proceed over large areas.

This uniformity is possible only in somewhat even-aged tracts. Great difficulties are expcrienced in mixed forests, owing to the difference of light requirements.

The fixed conditions inviting the forester to adopt this type are of a rather rare character, almost absent from primeval woods. ' 1 he education value of this type, however, is unparalleled.

B. Actual application: Shade bearers are better adapted to this type than light demanders. Beech is usually treated under this type; Maple and Ash frequently so; Oak largely in France, rarely in Germany; Fir and spruce in parts of the Black Forest; Pine in the old country but rarely owing to its demands on light.

This "military" type was ereated by George L. Hartig, toward the end of the eighteenth century. It was considered the ideal type of regencration up to about 1875. It is now far from being abandoned, maintaining its role as the most commonly used type of seed regeneration, although usually bastardized, in modern times, with the strip and the gromp type.

\section{Advantages:}

f. Thorough protection of the soil, of its productive capacity and its porosity.

II. Small risk of utter failure.

III. Large tracts taken in hand at one and the same time.

IV. Methodieal, military mamner of proceeding which facilitates instruction of the staff of rangers and proper execution of orders by the staff.

$V$. Mother trees, standing above the young growth in isolated position, yield an extra-increment of high value ("light increment").

VI. Young growth is well protected against climatic adversities.

\section{Disadvantages:}

I. Difficulty of obtaining a desired mixture of species in the young growth. 
II. Necessity for the entire number of old trees to reach maturity at or about at the same time.

III. Even-aged forests are formed by this type which are badly endangered by insects, fungi, storm, snow, etc.

IV. The young growth is badly damaged during the latter stages of logging operations, especially where heavy logs (not wood) are obtained and where the road system is deficient; further on steep slopes.

E. The uniform system, being particularly instructive, deserves a most detailed consideration.

To the mother trees is allotted a three-fold task, viz.:

To seed the "regeneration area."

To protect the young growth from atmospheric hardships and weeds.

To prevent deterioration of the soil during the early stages of the second growth.

Three distinct stages of regeneration must be distinguished, viz.:

I. The "preparatory stage," initiated by a preparatory eutting.

II. The "seeding stage," initiated by a seeding cutting. place.

III. The "final stage," during which the final fellings take

I. The preparatory stage:

a. Purpose: The preparatory cutting intends:

1. To prepare the soil underneath the mother trees for a seedbed, by increasing the rate of disintegration of vegetable matter. The soil is best prepared at a time when no weeds, but a few shoots of sweet grasses appear here and there. The humus decomposes at the quickest rate on limestone; at the slowest rate on sand and sandstone.

2. To prepare the mother trees for regeneration by allowing them a larger crown space, thus inviting the development of seed buds; further by increasing their stability, so that they may resist the storms when placed in a more isolated position;

3. To remove undesirable species, thus preventing them from propagating their kind.

4. To reduce the volume of the growing stock so as to facilitate the maintenance of a normal growing stock and so as to have less material to remove when the young growth appears on the regeneration area.

b. Duration: The duration of the preparatory stage depends upon the species and the soil. Shade-bearing species found in dense 
stands need a longer period of preparation than the light-demanding species. On soil rich with lime and in the lowlands, the preparatory stage is much shorter than on sandstone and in the highlands.

c. Area: The area (in per cent. of the entire forest area) to be prepared depends upon the necessities of the market and of the mill (equal annual yield), on the prospects of a seed year, on the frequency of seed years, and on the urgency of other fellings.

d. Trees: The preparatory cutting should remove all sickly trees and all undesirable species. Further, those which have the crowns low down to the ground, which will shade the young growth later on and which now lessen the rate of disintegration of vegetable matter. No dominant trees should be taken out. Near the edge of the compartment it is wise to keep the leaf canopy as close as possible, so as to prevent the inflnence of drying winds.

e. Marking: The forester limself should mark every tree to be taken out during the preparatory stage. When the wood cutters are not reliable, it is necessary to mark the stumps of the trees as well.

f. Lumbering: Where it pays to dig out the tree by the roots, it is well to do so, because a better seed-bed is the result. Care should be taken that only trees marked are felled, and that those left are not damaged. There is no need to move the firewood and timber out to the roads, if the regeneration area otherwise allows of snaking, wagoning, etc.

g. Pasture: Cattle should not be admitted any more for pasturage during the preparatory stage. Pammage of hogs will be of good advantage. Mice and insects are eaten by them. Hogs break up the net work of roots, leaves and moss forming the soil cover and hindering germinating sceds from catching root.

\section{The seeding stage.}

a. Time: The best time for "seeding eutting" is a seed year.

The forester should be able to tell from the looks of the buds whether a seed year is at hand. The frequency of seed years depends on the species and on the locality.

If there is no prospect for seeds, the seeding cutting should be postponed, and if a sustained yield is desired, it should be made up by preparatory euttings, final euttings and thinnings.

b. The area over which the seeding cutting should extend depends on the area prepared for regencration, on the length of the period of regeneration, on the periodical occurrence of seed years, on the requirements for a sustained yield and on the available market. 


\section{THEART OF THE SECOND GROIVTH}

The scarcer the seed years, the larger is the area placed in the seeding stage when a mast year arrives.

The longer the period during which the seedlings require shelter, the larger is the area to be taken in hand at a seeding cutting.

c. Trees: It is wise to take the biggest trees first, as their removal at a later date will result in great damage to the young growth.

If the forester is sure to be able to remove some more trees after the lapse of one or two years, a light seeding cutting is usually best.

During the first two years of their lives the young seedlings stand a great deal of shade, even those of light-ciemanding species, on fair soil.

The degree of light which should fall on the ground after a seeding cutting, depends on species, height of trees, form of trees and locality.

In the case of tender and slow-growing species, the cover should be close. In the case of tall trees, slight interruptions of the leaf canopy are sufficient.

On good soil, where weeds are to be dreaded, the cover should be denser than under the reversed conditions. On a southern exposure, the cover should be dense. Fir, Beech and Spruce require a close stand of the mother trees on strong soil and at high elevations.

Oak and Pine on alluvial sand of average quality should be tapped heavily.

d. The proportion of trees left and trees cut might be gauged by:

1. The distance or space between the crowns. It is very difficult to give any data as to the best distance of the crowns. The form of the crowns is so irregular that it is impossible to ascertain the best average distance.

2. The number of stems which gives a good idea of the cover overhead where yield tables are at hand, if the age and the locality are known.

3. The sectional area of the stems cut and of the stems remaining.

4. The volume cut and the volume remaining.

e. Preparation of soil: Shade-bearing species maintaining the porosity of the soil better than light-demanding species often allow the forester to get along without any preparation of the soil. Under light-demanding species, on the other hand, the hardening of the soil at the time of seed cutting often necessitates the preparation of the ground so that it may serve as a seed-bed. This preparation may consist of : 
1. Removal of leaves, weeds or moss.

2. Working the ground by pasturing hogs.

3. Wounding the soil in open spaces, with a hoe.

4. Breaking the soil with a strong plow.

f. Lumbering. All eutting should be done as soon as possible after the seeds have dropped so as to bring them into contact with the ground at once. The wood or timber cut should be dragged to the roads previous to the germination of the seeds. The heavier the seed cutting is, the larger will be the percentage of seeds finding germination. Most of the seeds are imbedded by the steps of the roodsmen.

Advance growth should be removed wherever it appears singly. Care must be taken that remaining mother trees are not damaged by lumbering.

g. Covering the seeds: The covering of the seeds is left to nature or to hazard. It might be advisable, however, to secure a covering artificially with the help of a rake, or by plowing, after the seeds have dropped, or by pressing heavy seeds (nuts, acorns) into the ground with a blunt stick.

h. Fire: After the seeds have dropped, the utmost eare must be taken to prevent fire from running through the forest. A fire previous to the dropping of the seed may be advantageous, especially in the case of Yellow Pines. After the sceding, however, it should be prevented.

\section{The final stage.}

The removal of the seed trees left takes place during the final stage.

a. Purpose: By the gradual removal of the mother trees, the young forest is gradually lead into a life under changed conditions, until it is ready to enjoy the full influence of sumshine, air and rain.

b. Number of cuttings: The more gradual the removal, the less damage results for the young growth from the logging operations and from changed environments. On the other hand, it is cheapest and best, from the logger's standpoint, to remove the seed trees at one stroke.

c. Beginning: The beginning of the final fellings depends on the development of the young growth. In the case of poor soil, of lightdemanding species and of northern climate, fellings should start in the fall following the seeding.

In the case of shade-bearing species, strong soil and southern climate, the second or third fall should be waited for. The drier the locality, the quicker must be the removal of the mother trees. 


\section{THE ART OF THE SECOND GROWTH}

d. Duration: The duration of the final stage depends on species, on quality of soil, on success of seeding eutting, on occurrence of subsequent seed years and on climate. A tender, slow-growing and shade-bearing species allows of a protracted period of removal.

A few trees left in isolated positions are apt to damage the young growth by the reflection of the sun's rays from the bark; this is the case especially in species having a whitish bark (Beech, Maple, Birch, Silver Fir).

e. Marking for final removal: Broad-leaved trees should be marked in summer whilst the trees and the young growth are in leaf.

By the first final felling none but small trees shall be removed, after Hess. From the second fall (after the seed cutting) on, the seedlings being stronger at that time, it is wise to take the largest trees.

f. Season: The cutting of the mother trees should take place when snow covers the ground, so as to do the least possible damage to the young growth. Fellings must be discontinued during hard frost. Broad-leafed species should not be cut before leaves are dropped as they will do more damage to their progeny when felled in leaf.

Hess is in favor of cutting in fall, claiming that the young growth at that time is particularly tough and elastic. He does not attribute much weight to the presence of snow unless it covers the young growth entirely.

g. Stumps and roots: If the trees are dug.out by the roots, the force with which they hit the ground is considerably lessened.

In coniferous forests, many parasitic insects breed in stumps, and in that case it may be necessary to dig them out of the ground, or to poison them.

Where the tree is entirely surrounded by young growth, digging should be prohibited.

h. How to fell a tree: The tree to be cut should be thrown onto that place where it is likely to do the least damage-especially onto "blanks." It is wise to throw the erowns of several trees onto the same spot so as to centralize the damage. On the other hand, many sylviculturists prefer to throw the crowns of the trees into the very thickest young growth, elaiming that the damage thereby done is considerably less, and that many youngsters will be left undamaged.

i. Standards: In many cases, a few trees are left standing for a second rotation. Such trees are called "standards." Standards of Oak, Pine and Ash are frequently found. They should not be 
left unless they stand close to a road, or unless they are certain to outlast a second rotation.

j. Pruning of mother trees: Low branches which overshadow the young growth heavily should be cut.

k. Transportation of wood: All wood and timber should be moved to the nearest roads as soon as possible after the trees are cut. Speedy removal is especially necessary in coniferous forests, the young growth having little reproductive power. A snow cover might be used to remove the wood on sleds; high-wheeled trucks will answer splendidly on level ground. The method of "roping" used in the Black Forest also saves the young growth. All wood and timber must be removed from the regeneration area previous to the opening of the buds.

1. Pasturage: There is no need to say that the young growth should be protected against pasture.

m. Reinforcing: Blanks should be filled only when the mother trees have been entirely removed. The plants may be taken from dense places where the natural regeneration is complete or, better, from nurseries.

\section{Paragiaph XLIX. The shelterwood strip type of natural seed regeneration.}

- A. This type bears the same ratio to the shelterwood compartment type of regeneration which the cleared strip type bears to the cleared compartment type.

In the shelterwood strip type, as in the eleared strip type, fellings and regeneration begin at the leeward side of a compartment (cove, slope) and proceed gradually against the direction of the prevailing storms, or else from the North to the South.

Heavy-seeded species as well as light-seeded species allow of the strip type. Distinct light demanders, however, defy it on the poorer grades of soil.

The muclei are laid orit geometrically in the shape of strips crossing the prevailing wind-direction at right angles. The most leeward strip is in the final stage; the most windward strip is in the preparatory stage; the middle strip is in the seeding stage, provided that the conditions are normal.

The breadth of a strip depends on species, frequency of seed years, configuration of ground and so on. At a breadth of over 500 feet, the strip type bastardizes with the compartment type. 


\section{THE ART OF THE SECOND GROWTH}

More frequently, the shelterwood strip type is bastardized with the shelterwood group type (e. g., in the famous Bavarian forests near Kchlheim).

Regeneration of a cove, slope, tract, etc., under the pure strip type, is exceedingly slow, unless there are at hand a number of "series of strips," all triplets, consisting of a preparatory, a seeding and a final strip.

The first strips are usually made, as in the eleared strip type, in well-sheltered ravines or gullies; or at the windward edge of lakes, fields, young growth; or at the windward edge of storm-firm trees (Oaks), where there is a mixture of storm-firm species with species endangered by storm.

The form of the strips need not be exactly rectangular. In the mountains, the strips usually run up and down the slopes-not horizontal-so as to facilitate the transportation of timber and wood removed from the strip.

B. Actual application: This type is frequently seen in the coniferous woods of the European moderately cold zone; also in Beech wools and Oak woods.

Like the uniform type, the strip type is not exactly natural.

In the Spruce woods of the Appalachians, where the wind lays low one row of trees after the other, in the course of many years, the woods look frequently as if they were regenerated by the shelterwood strip type.

C. Advantages: The advantages of the shelterwood strip type are ilentical with those of the shelterwood compartment typeexcepting advantage III. It is especially adapted to small pieces of property, which could not yield steady returns under the uniform type. Greater security from storm is characteristic for the strip type. Liberty of action, since there are many points at which the annual cut may be made, is a further advantage.

\section{Disadvantages:}

I. Difficulty of obtaining a desired mixture of species in the young growth.

1I. Trees at the extreme windward edge of a cutting series obtain an extravagantly high age, whilst regeneration proceeds slowly and gradually against them.

III. Tardiness of a complete regeneration of a whole compartment, slope or cove, where there are but a few points of first attack.

IV. Operations are more scattering than in the shelterwood compartment type. 


\section{Paragraph L. The shelterwood group type of natural seed regeneration.}

\section{A. Characteristic features.}

I. Species: All species ean be dealt with in a group system; those endangered by windfall, however, require a modification of the system, or a smill rotation, or a regular progress of the groups toward the storm danger.

II. Beginning: In the shelterwood system, the nuclei for groups are formed at a time, at which the soil begins to be, here and there, a ready recipient for seed. In the mucleus, two or three trees are cut, to begin with, and a few seedlings soon enter an appearance.

III. Continuation: The young growth gradually spreads out, more or less peripherically, from the nucleus, appearing at the feet of the nearest trees. These trees, in turn, are gradually removed, whilst the groups of scedlings contimue to enlarge. Finally one group will flow into the other, and the regeneration will present a waving leaf canopy. The regularity of the canopy depends on the rapidity with which the groups could be enlarged.

IV. Means of transportation: The type obviously requires a finely meshed, permanent network of transportation. The axe returns to the group under formation periodically, say every three to ten years, during a period of regeneration comprising from fifteen to fifty years.

T. Soil protection: The soil is eontinuously protected from intensive insolation, and is hence kept in continuous productiveness.

VI. Dangers: Protection from fire is very difficult; protection from storm difficult, although easier than in the shelterwood compartment type. Insects, fungi, and snowbreak are not to be dreaded much more than under the selection system.

VII. Lumbering: Mother trees are always felled in a manner forcing them away from the group. Hypermature trees close to the group are extracted at the same time. Lumbering operations are necessarily seattered. The logging expenses and the cost of supervision range very high. The removal (snaking) of the trees ent takes place through the benches of trees left between the groups so that the soil is stirred up continuously within the benches.

The groups should be started, if possible, at the upper end of a slope so that the $\operatorname{logs}$ need not be snaked through young growth.

VIII. Artificial help: To start regeneration of a nucleus, and to accelerate the enlargement of a gronp, mosses, weeds and litter on the ground may be removed previous to a seed year (bastardizing with advance growth group type). 
The so-called "hair-dressing" of groups, by which misshapen and branchy growth is cut back, and the wave-form of groups is maintained, may be seen in the Black Forest.

B. Actual application: The shelterwood group type appears to be a type of regeneration sometimes adopted by primeval nature in Beech, Maple, Fir, Hemlock and Pine woods.

As a sylvicultural method adapted to the woods of Germany, the shelterwood group system has been fathered by Charles Gayer.

It is a modern type of German n. s. r., applied especially in the natural seed regeneration of Spruce and Beech.

\section{Advantages :}

I. The type grants the forester the utmost liberty of action, by offering him a large number of points at which to start and at which to continue his logging operations.

II. In mixed forests, the system allows of fostering the most valuable species and of checking the less desirable species or the weed species.

III. The type does not take any sylviculture chances.

IV. The young growth is well protected against the usual atmospheric dangers.

$\mathrm{r}$. The good qualities of the soil are carefully husbanded.

\section{Disadvantages :}

I. The type makes unusual demands on the personal and local attention of the manager as well as of the staff, necessitating small ranges and high administrative expenses.

II. Nother trees at the leeward side of an enlarged group are subject to dangers from storm; on the northeast side of a group subject to dangers from sun scald.

III. A large outlay is incurred for logging the trees owing to the scattering character of the operations and owing to the care required in felling and transportation, for the benefit of both young and old growth.

IV. In the case of very large trees, covering by their crowns as much as 500 to 1,000 square feet, the removal of an individual tears too big a hole into the forest and enlarges the group too rapidly at a stroke.

$T$. The type does not allow of the removal of hypermature trees with proper expedition. They are not removed but when the waves of the group begin to touch their feet.

VI. The soil in the proximity of white barked trees bordering a group is scorched by reflected sun rays. 


\section{Paragraph LI. The shelterwood selection type of natural seed regeneration.}

This type scarcely exists in a pure form. Where it exists, it is invariably bastardized witl the eleared selection or the advance growth selection type of natural seed regeneration.

The pure type would imply the immediate development (or rather the simultaneous development) of a seedling growth in the very year (a seed year) in which the individual trees-very irregularly, very scatteringly, on the basis of their relative maturityare selected for removal.

Where the removal leaves a blank, there we meet the cleared selection type.

Where the removal allows an advance growth already at hand to fill the gap, there we meet the advance growth selection type.

The premises for the shelterwood selection type are identical with those for the eleared selection type and for the advance growth selection type.

\section{Paragraph LII. Types in which lumbering fol- lows natural seed regeneration.}

In these types of natural seed regeneration-so-called advance growth types-no tree is removed unless its foot be already surrounded by a young progeny of desirable character which has previously developed beneath the parent's or step-parent's leaf canops.

The case of exceedingly fertile soil and the case of step-parents having a light leaf canopy excepted, none but absolute shade bearers can be propagated by this type. So e. g., Hemlock, Fir, Beech, Maple, Lawson's Cypress, Western Red Cedar.

In the Lake States, White Pine is found as a regeneration formed in advance beneath mature Norway Pines acting as stepparents (advance growth group type).

In the Adirondacks, Spruce regenerates similarly underneath mature Cottonwoods acting as step-parents or, on very fertile soil, selectionwise beneath Beech, Maple and Birch.

Striking it is that species not absolutely shade enduring are, in mauy a case, loth to be regenerated, as an advance growth, at the feet of their actual parents, whilst willing to be suppressed beneath step-parents of apparently similar density of foliage (Yellow Poplar at Biltmore underneath Oak or Short-leaf Pine; Spruce underneath Cottonwoods). 


\section{THE ART OF THE SECOND GROWTH}

Seedlings regenerating under their own kin resemble altricial (nidicole) birds; seedlings avoiding parental superstructure might be likened to precocial (nidifugal) birds.

A. The chances for successful regeneration in these types stem excellent. Still, the following points must not be lost sight of:

I. Advance growth badly suppressed for a long time is frequently so badly crippled that it fails to recover within a reasonable number of years.

II. The advance growth is badly smashed by and during the felling operations, unless the mother trees are pruned and lopped before felling, and unless the timber obtained is carried out either by hand, or on high wheel trucks, or on a heavy cover of snow protecting the advance growth. Under any circumstances, fellings during the period of vegetation must be avoided.

III. Advance growth suddenly exposed to the full influence of sun, rain, snow, sleet, ete., is apt to suffer in case of sensitive species.

IV. A minute system of permanent roads is required, the advance growth usually appearing in groups or patches.

$T$. If the pure types of advance growth n. s. r. were strictly adhered to, a regulation of the annual cut according to the conditions of the market would be difficult to obtain. Hypermature trees would have to be left everywhere-merely because young growth is often slow to form on their feet.

In such cases, artificial preparation of a seed-bed (e. g., by uncovering the mineral soil) seems absolutely required, so as to expediate the formation of an advance growth.

If the leaf canopy overhead is opened at the same time by felling operations, the types bastardize with the shelterwood types of n. s. $x$.

B. According to the extent of the area covered by an advance growth of suitable character we distinguish between:

I. Advance growth compartment type of n. s. r., the areas uniformly covered by advance growth measuring from twenty to one hundred acres (rare).

II. Advance growth strip type of n. s. r., the areas uniformly covered by advance growth appearing as strips measuring up to 500 feet in breadth (very rare).

III. Adrance growth group type of n. s. r., the groups covered by advance growth having an extent of from one-tenth to four acres (frequent).

IV. Advance growth selection type of n. s. r., the young seedlings and saplings appearing in scattered and small patches (very common). 
By "advance growth" is understood an aggregate (small or large) of seedlings or saplings belonging to a desirable species and formed without any human intention or attention, solely br nature, beneath a totally or partially untouched leaf eanopy orerhead.

Misshapen advanee growth appearing in bunches or groups ean be doetored up with axe and brushhook and maeletes, by an applieation of "hairdressing."

Where the advanee growth is not freed, by one single operation, from the superstructure of parents and step-parents overhead, the advance growth types are further bastardized with the shelterwood types.

\section{Paragraph LIII. The advance growth compart- ment type of natural seed regeneration.}

A. The type is applicable where large areas exhibit on strong soil a uniform advanee growth, eonsisting of seedlings, of saplings and possibly of small poles.

Previous to lumbering, the leaf canopy consists of two tiers: an upper tier formed by the parents (or step-parents) and a lower tier formed by the advanee growth. Lumbering removes the upper tier entirely and leaves the lower tier intact-if possible.

In the safety of the lower tier lies the great difficulty of the system, especially on rough ground, in handling heary logs of the superstructure, in dealing with cheap stumpage, in cutting soft woods charaeterized by small healing power and in the absence of an intricate system of transportation.

Where the upper story of trees consists of say 10,000 feet b. m. per aere, or of more, the gromnd is literally littered with logs or boles during the logging operations, and the advanee growth has but a slight ehance to survive the death of its progenitors.

B. Actual application: The type is found, in rare cases, abroad under the misnomer of a modified "seleetion system," where and when the logger returns for a wholesale removal of mature trees, at intervals of about twenty years, to the same compartments.

The type is also practical where prolific secd years produce, in mild sites and on strong soil, a uniform advance growth in evenaged Beech or Firwoods, without any previous luman interference with the leaf canopy overhead (so-ealled regeneration from a complete growing stock). 
In the hardwood forests of Michigan, light surface fires tend to destroy the heavy litter on the ground, and to produce a wonderful crop of seedlings (Hard Maple, Beech, Elm), long before the logger begins to operate. On Star Island, in the Minnesota National Forest, fire has made possible the development of a fine stand of seedling White Pine beneath a dense stand of Red Pine. Where the litter is raked away, in the Southern Pineries, to be used on the rice farm, a healthy growth of Pines is allowed to come up, before the axe touches the trees. The splendid regenerations of Scotch Pine at Ysenburg, Germany, have been obtained by this type on soil deprived of its leaf mould.

In the United States the removal of the superstructure, usually followed by fires, tends to annihilate every restige of advance growth.

\section{Advantages:}

Where the system can be carried through, it offers the following advantages:

I. Concentrated logging.

II. Well-preserved productiveness of the soil.

III. Soil never idling, but producing without any delay.

D. Disadvantages:

I. The type is applicable only to intense shade bearers; and these shade bearers are very apt to snffer from sudden ehanges of environments.

II. The logging expenses are very badly increased in the attempt to save the advance growth from destruction.

III. Under any circumstances, the rapid removal of mother trees inflicts scars upon the young growth apt to serve as entrance gates for fungi and insects.

\section{Paragraph LIV. The advance growth strip type of natural seed regeneration.}

A. Advance growth, being a chance product, is rarely found in symmetrical, long-drawn strips. Where the cleared striptype is introduced, however, a strip of advance growth is often and easily started underneath the border trees joining the cleared strip to the windward. In that case, the advance growth strip-type is o bastardized with the cleared strip-type.

\section{B. Actual application:}

The type is found but in the bastard form just mentioned. 


\section{Advantages:}

I. No expense required for regeneration (minless weeds, leaves or moss are removed).

II. Advance growth is readily saved, where the logs are removed through the adjoining woods.

III. A road system touching the lower edge of the strips is sufficient.

IV. Soil is never laid bare.

V. Little clamage from windfall.

D. Disadvantages:

I. Scattering operations.

II. Type is not applicable to light demanders.

III. Hypermature trees must be left in the woods until the strips, after many years, may approach them.

IV. Points of attack from which cutting may proceed are apt to be lacking. unless the forester, helped by th: configuration of the ground, is able to maintain a large number of narrow cutting series.

\section{Paragraph LV. The advance growth group type of natural seed regeneration.}

A. In nature, advance growth usually appears in small bunches or in groups, for the reason that there is always a chance. for many seedlings to sprout and develop on a spot where light, humidity and soil allow a single individnal to make a start alone. In the primeval woods, groups of advance growth formed by shadebearing species are almost invariably at hand. Even light demanders may form small groups of advance growth in spite of a superstructure overhead, provided that the soil is strong enough to support them.

Such groups, freed from the trees superstructing them, will develop one or a number of saplings which in turn and in course. of time may yield one or a few poles promising to grow into trees. of a loggable size.

Very frequently the groups are formed not under the leaf canopy of the parent species, but underneath another species acting as a step-parent.

Indeed, step-parents of a rather selfish kind, inimical to the children, are frequently encountered in tree life, handicapping and killing the young progeny thirsting at their feet for light and rain.

The endurance of advance growth living under adverse condi- 
tions is at times remarkably great. Fir, Spruce, Beech and Maplemay be met grown but six feet high when sixty years old, retarded by parental superstructure.

The pure advance growth gromp type is frequently bastardized, in Enrope, with the shelterwood group type when the forester uses existing groups of advance growth as nuclei to be gradually enlarged, instead of using spots as nuclei for group regeneration on which the soil chances to be in a conceptious condition. Further, when a shelterwood group is forming, advance growth groups are frequently started, under the influence of side light on seedlings and humus, at a goodly distance from the shelterwood group, underneath an apparently heavy superstructure of mother trees.

The advance growth group type pure and simple, however, merely implies the freeing of chance growth from a superstructure. It has nothing to do with the gradual enlargement of a group by ringwise cutting around the group.

The "hairdressing" of groups of advance growth is sometimes commendable.

B. Actual application: Systematically, this type is nowhere. applied in its purity. Accidentally, however, the lumbermen of America happen to employ it in woods composed of Fir, Hemlock, Maple, Beech, ete.

Primeval nature employs this type quite largely.

C. Advantages: The advantages of the type are identical with those given under C, I, II and IV, in paragraph IIV. In addition, this type may often allow the forester to favor a desirable species of shade-bearing character.

Under sylvicultural care, it renders regeneration an absolute certainty. The trees forming the superstructure frequently happen to be of a marketable size. The type does not require much sylvicultural understanding.

\section{Disadvantages:}

I. Border trees to the leeward of advance growth are subject to windfall and sum scald.

II. Advance growth groups continue to be badly suppressed, along the edge of the group, by border trees.

III. The logging operations are scattering, and an intricate. system of permanent roads is required.

IV. Only intense shade bearers can be properly managed under this type; light demanders found in mixture with shade bearers must gradually disappear from the mixture. The shade bearers will form groups of advance growth readily underneath light demanders : but not vice versa. 


\section{Paragraph LVI. The advance growth selection type of natural seed regeneration.}

A. This type is usually bastardized with the eleared and with the shelterwood selection type.

The selection by the forester of trees to be chit might be either by single trees or by very small bunches of trees underlaid with a carpet of advance growth covering about one-one-hundredth acre of ground.

The logging operations, as in all selection types, are exceedingly scattering; indeed, they ought to continuously extend, as a matter of theoretical prineiple, over the entire forest.

None but shade bearers, notably Fir, Hemlock, Maple and Spruce, are well adapted to the type of advance growth selection.

The type, like the cleared and the shelterwood selection type, renders the construction of an intricate network of roads necessary. Every tree, so to speak-not every strip or every compartment-must be continuously accessible.

Since the cuttings are comparatively light, the removal of the logs prepares the ground insufficiently for the conception of seed.

An advance growth stands under very heavy shade for many a year; usually in small bunches of a dozen specimens. Misshapen seedlings and saplings, also those badly damaged during logging operations, should be eut, or in the case of hardwoods coppiced.

\section{B. Actual application:}

Wherever the selection type is applied in Europe, it is preeminently applied in the shape of advance growth selection type; especially so in parks, in small farm wood lots and in protective forests. Usually, every compartment (eove, slope) contains a wild mixture of age classes of trees. The axe returns to a compartment in intervals of from one to ten years.

The Beech, although an intense shade bearer, develops very branchy stems under such conditions (Beech forests in Buckinghamshire, England, or near Louisville, Kentucky).

In primeval nature, all or practically all seattering and sparse species are subjected to seed regeneration of the advance growth selection type. The accidental death of trees in the superstructure allows a patch of advance growth found underneath to develop into trees.

Instances: White Oak and Scarlet Oak at Biltmore; Spruce on hardwood slopes in the Adirondacks; Hemlock in the Maple woods of Michigan.

It is surprising to find that seattering species are regenerated 
by primeval nature in a type which is considered by the sylviculturist applicable to none but intense shade beare1s. The explanation lies in nature's long-lasting patience and in her failure to be disheartened when failing in innumerable attempts.

\section{Advantages :}

I. The type protects the soil, and hence the waters, best of all.

II. It protects the young growth from frost, drought, high winds, insects, sleet and snow.

III. It is particularly pleasing, from the rsthetic standpoint, by the unusually large variety of the pictures proflered.

IV. Since every acre of ground continuously retains its leaf canopy, no sunshine, air and rain go to waste in a second growth insufficiently covering the areas laid bare. At the same time, continuous retention of moisture in the soil allows of greater fertility; hence the quantity of wood fibre annually produced is greater in the selection type than in any other.

$\mathrm{V}$. Small danger from windfall amongst parent trees.

VI. Small danger from fire, since the humus is kept moist contimuously. On the other hand, a fire once broken out is extremely hard to stop.

\section{Disadvantages :}

I. Logging operations are very scattering, and hence expensive.

The fall of individnal, large trees amongst the multitude of their companions is very apt to inflict wounds upon them, through which fungi and insects enter readily.

II. A minute net work of permanent roads is required.

III. The primeval woods, wherever they represent the selection type, show a preponderance of mature and hypermature age classes. Since the type does not allow of the removal of groups of trees at all, and of the removal of individuals only where they are underlaid by an advance growth, the owner of primeval woods adopting this type is forced to bring heavy sacrifices.

$I V$. It is very difficult to regenerate light demanders by this type, where they stand mixed with shade bearers.

\section{Paragraph LVII. Regeneration of valuable species from self-sown seed with, amongst and into companions of a weedy character.}

It is a well-known fact that none but a few of the hundreds of seedlings raised (artificially or naturally) by the forester have a. chance to develop into poles, trees and veterans. 
Dense thickets, consisting of many saplings, are merely required to maintain the fertility of the soil and to prevent, by natural pruning, the young boles from growing into brushy and branchy specimens ("orchard trees").

For the purpose at stake it is immaterial, in a sense, whether the thickets consist of a "mob" of shrubby weeds mixed with a few "aristocrats" hailing from valuable species, or whether the entire thicket consists of "artistocrats." More than that; whilst the aristocrat may have at best a small value as a sapling or as a small pole, the "mob" frequently is more çonducive to proper soil protection and to proper development of the "aristocracy" into large poles and standards than a purely artistocratic crowd.

The danger, of course, prevails in mixed stands continuously lest the aristocrats might be overtopped and killed by the mob.

A. Wherever the mob consists of evern-aged seedlings (not of stoolshoots) of shrubs, that danger is small, shrubs nsually exhibiting a slow rate of height growth (Alder, Dogrood, Hazel, Witchlazel, Rhododendron, etc.).

Stoolshoots of slirubs, on the other hand, frequently grow so fast, so dense and so rank that they are sure to overpower an aristocracy of seedlings having the same age.

If the mob promises to easily obtain the upper hand, then it is usually wise to delay regeneration until the shrubbage shows, at a much later year, signs of a declining growth (Calmia); or else to wait until the shrubs allow a deadening (Dogwood); or to fire the slrubbage (Blackjack) in heavy seed years of the aristocratic parentage; or to lumber heavily if the shrubs (Striped Maple) are sensitive and if the aristocrats are hardy.

Certain weedy shrubs, e. g., Bamboo speeies, offer periodically a chance for subdual, viz., when death overtakes them gregarionsly during their own seed years.

Other shrubs are eagerly eaten (or peeled) by shcep, goats or eattle, and might be brought to submission, in the winter following the fruiting of the aristocrats, by heavy pasturage.

The purpose at stake, in American Sylviculture, for years to come, cannot consist in homogeneons regenerations of aristocrats evenly covering the regeneration area; it ean consist in but that form, quality and density of regeneration-usually a partially snecessful regeneration-which the forester considers financially most desirable (compare paragraph XLI. E).

The extirpation of shrubs by pickaxe and plow is usually impossible, unless it can be combined with "toungya." 


\section{THE ART OF THE SECOND GROIVTII}

It is often sufficient for the increase of an aristocratic regeneration to break or reduce the humus formed underneath the shrubbage.

\section{B. The battle against weed trees trying to propagate}

their kind in the forest is usually more difficult to win than that against shrubs since the progeny of weed trees does not stop to compete with aristocrats after the thicket stage. The forester must carefully gauge the chances for a final victory--usually a partial victory - of the aristocrats, footing on a knowledge of their relative height growth and their relative shade endurance.

Weed trees might be prevented from successful seeding by:

I. Deadening or stump peeling.

II. Actual removal (unless resulting in rauk stoolshoots).

III. Sudden exposure of young progeny to draught or frost.

IV. Maintenance of a dense humus, or of a dense leaf canopy.

V. Pasturage.

VI. Stopping all logging operations during seed years of the weed-tree species.

VII. Fire.

Any of these remedies will answer on a regeneration area provided that it inflicts greater damage on the weed trees than on the aristocrats, and that the success is fully commensurate to the expense.

A careful choice of the type of regeneration (cleared, shelterwood, and advance growth types in compartments, strips, groups or patches) is, however, the best weapon in the hands of the forester against mobbish usurpation.

The time may come when the forester will avail himself of plagues of fungi, vertebrates and insects in the struggle against weed trees.

Obviously, where the logger, followed by fires, removes every vestige of the aristocracy and every chance for its reproduction on deteriorated soil, there the sylvan battle is lost for the forester before it is begun.

Frequently in nature's economy and ecology a crop of weed trees (Birches, Cottonwoods) intervenes between two generations of aristocrats. This "rotation of crops" resembles that of agriculture, and is hard to explain. Attempted explanations are: Exhaustion of soil in mineral matter required by the previous species. Presence of baccilli, bacteria, fungi, insects, etc., inimical to the previous species. 


\section{Paragraph LVIII. Pedagogie of the seed forest.}

The term "pedagogie" comprises the principles and rules which pertain to the training of the young.

Forest pedagogie, or forest tendance, the second part of the sylviculturists' activity, is of little importance in America at the present time since there are no young forests at hand which might be trained profitably. Forest protection, usually considered a branch of forestry, is merely a branch of forest pedagogie.

The following operations are here treated under the heading "forest pedagogie."
A. Cleaning
B. Weeding
) Indirectly remunerative acts or investments.
C. Improvement cuttings ? Directly remunerative acts yielding
D. Thinning a surplus revenue.
E. Pruning
F. Underplanting
) Indirectly remunerative acts or
$\int$ investments.

The definitions of the terms "cleaning," "weeding," "improvement cutting" and "thinning" are so indistinct that it is often difficult to differentiate them. Definitions might be based either on the age of the wood crop tended, or on the purpose aimed at, or on the financial side of the tending.

Cleaning and weeding are applied for the benefit of very young growth and usually require an investment.

Pruning, thinning and improvement cutting are applied for the benefit of thickets or polewoods.

Improvement cuttings and thinnings usually furnish a surplus revenue whilst pruning succeeds in but rare cases to be directly remunerative.

Mr. H. S. Graves, in "The principles of handling woodlands," applies the term "improvement cuttings" to any and all cuttings primarily meant to improve, and not to reproduce the forest. His definition abandons the distinct and restricted meaning given to the term in the English forest literature.

\section{Paragraph LIX. Cleaning in seed forests.}

Cleaning may occur during the seedling stage and the small sapling stage. It implies the removal of saplings forming a shrubby advance growth (wolves); or the removal of undesirable 
stoolshoots; or the removal of seedlings and saplings belonging to a less-desirable species competing for space in a young forest. In natural seed regenerations, cleaning is particularly desirable. Instances: Removing poor coppice shoots which oppress by faster growth the valuable seedlings of Yellow Poplar. Removing Birch, Fire Cherry, Thorns and Briars in young plantations of White Pine, Yellow Pine and Spruce. Where a regeneration area of strong soil has been burned previous to planting, the competition of volunteer growth is frequently such as to make cleaning necessary. The forester should take care, however, not to extirpate species now of little value, but possibly of a fair future value.

In mixed regeneration, cleaning offers a good means to regulate the proportion of the species admixed. The expense incurred for cleaning must be commensurate to the financial eflect of the operation. Instruments used are axe and brush hook; also long-handled cleaning shears.

Occasionally, sheep or cattle allowed to come to pasture in the woods do more good by cleaning than harm by preying on the valuable seedlings.

Where the Spruce comes up "as thick as "the hair on a dog" the Saxon forester considers it wise to traverse the thicket by narrow lanes some three feet wide and some ten fcet apart.

\section{Paragraph LX. Weeding in seed forests.}

A plant, either herbaceous or ligneous, which has a negative value is a "weed." It night be a cripple of an otherwise very valuable species (fire-crippled Chestnut in Pisgah Forest), or it might belong to a species having no commercial value (Rhododendron, Witch-hazel, Black Gum, Halesia, Chinquapin, Alder, Beech).

Weeding implies the removal of large saplings, poles and trees having the character of weeds. Weeding may take place before regeneration, or after regeneration has been started. It may act incidentally as a preparatory cutting, a sceding cutting or a final removal. It pays but indirectly since the stuif removed has a negative value.

The purpose of weeding might be the extirpation of suppressors of young growth; or an exchange of unhealthy crooked, fire-scalded, flat-headed poles for new, vigorous stump sprouts (Spanish and White Oak at Biltmore).

The term "weeding" is not found in books on Sylviculture; it 
forms, however, under present conditions often one of the most important and most remunerative sylvicultural acts.

Weeds are either girdled (deadened) or cut.

In the case of weeds having a diameter of over six inches, girdling is often preferable, because cheaper than cutting. Moreover, the cutting of broad-leafed weeds often tends to merely replace the weed by weed sprouts.

To prevent this, in the case of sapling weeds, erushing shears might be used.

Some cottonwoods cannot be extirpated by deadening. In that case, the peeling of a strip of bark three feet long at a point two feet above ground is advisable. Cutting of weeds in August reduces the chances of their recovery. In the Adirondacks, the weeding of Beech overshadowing Spruce might be advisable, because remunerative.

\section{Paragraph LXI. Improvement cutting in seed forests. .}

A. The term improvement cutting was introduced into Indian practice by Sir Dietrich Brandis. Improvement cuttings are cuttings for revenue.

An improvement cutting, in the original sense of the term, extracts from irregular woods:

I. Hypermature, mature or dead trees still of value.

II. Misshapen immature trees.

III. Species of minor value.

IV. Weeds of pole size and tree size.

B. Essential it is for the character of an improvement cutting, that it is intended to result, on the aggregate, in a surplus revenue. Cuttings, on the other hand, which leave the premises in a materially decreased financial value, can, of course, not be considered as improvement cuttings. Again, cuttings made at a sacrifice, merely with a view to an increased prospective value of the forest, are "weedings" or "cleanings" which must be considered as investments, like the expenses spent for regeneration.

I. The purpose of improvement cuttings is:

a. A surplus revenue.

b. Improved financial prospects of the remaining erop carried about by: 
1. Removal of trees and poles acting as suppressors;

2. Removal of inferior trees and poles acting as competitors;

3. Partial removal of a superstructure on a regenerated area;

4. Removal of less desirable individnals acting as seed-trees.

c. Reduced danger from fire, fungi and insects.

II. Kinds of improvement cuttings are:

a. Improvement cuttings in primeval woods.

b. Improvement cuttings in culled roods.

III. Marking: Trees and poles to be removed in an improvement cutting must be individually marked by the sylviculturist.

Generalizing rules for marking cannot be given; each tree or pole must be dealt with according to its individual merits and demerits.

The marking of improvement cuttings by the forester is, consequently, a timetaking affair.

IV. Localities: Irregular, thin woods composed of a multitude of species deserve improvement cuttings.

The local market must allow of the--at least partial-ntilization of suppressing, competing, superstructing and less desirable individuals.

\section{Paragraph LXII. Thinnings in seed forests.}

Thinnings proper are applicable exclusively to dense and fairly even-aged groups or woods, in the thicket stage and in the pole stage thereof, always under the proviso that a perminent road system and a nearby market allow of a remunerative ontcome of the act. In Pisgah Forest thinnings are out of the question as the woods are thin and irregular. At Biltmore, thinnings are made in the polewoods of Yellow Pine. Up north, from the merely sylvicultural standpoint, thinnings are possible in the Jack Pine woods, in Balsam thickets, on Black Spruce slopes, in Lodgepole Pine thickets, etc.

Thinnings are not made to originate a second growth; they are made within a second growth already at hand.

\section{A. Purposes of thinnings:}

I. To develop the $\log$ diameter of large saplings and poles at a time at which the log axis has been obtained.

II. To increase the volume increment percentage.

III. To increase the quality increment of predestined messmates. 
IV. To reduce the danger from forest fires, insect pests, fungi plagues, wind, snow and sleet.

V. To remove cripples and wolves.

VI. Early financial returns.

VII. Reduction of investment.

VIII. Shortening of the rotation by feeding a lesser number of mess-mates on a relatively larger amount of fond (viz., moisture, heat, light, mineral matter, etc.).

IX. Regulation of the relative proportion of the species in mixed pole woods.

$\mathrm{X}$. Reducing the friction, and the consequent loss of side shoots, between crown and erown.

B. The season for thinning depends upon local climate, seasonable prices of labor, adrisability of peeling and intensity of thinning. The season usually selected for thinning in Europe is the late winter when the main cuttings are completed.

C. The time for thinning. Thimnings slould begin in the late thicket stage and should be repeated, to begin with, in five-year intervals, say from the year thirty to sixty. Thereafter the intervals are increased up to the year eighty or ninety. A preparatory cutting, although conducted like a thinning, is no thinning, since its purpose is regeneration. Thinnings stop at the end of the pole stage. Where poles are non-salable, thinnings cannot be made.

To raise homogenous timber, thinnings must be repeated at intervals of four to eight years.

D. The material obtained from a thinning may consist of firewood, pulp wood, mine props, fence posts, telephone poles, hop poles, hoop poles, tool handles, bolts for spokes, locust pins, tannin wood, ete.

Twigs and stumps and material almost worthless should be left so as to prevent a deterioration of the soil and so as to stimulate the bacterial life in the soil.

In European practice, the number of cubic feet obtained by thinnings during the course of a rotation per acre exceeds frequently, now-a-days, the number of cubic feet obtained by the final cut.

The tool used for thinning is the axe invariably.

E. Kinds of thinnings. The old doctrine was: "Thin early, frequently, moderately!"

This rule has been gradually abandoned during the past twenty sears. The method of thinning depends on its purpose. Wrilliam Schlich distinguished between quality thimnings, made to improve 
the timber quality of the trees left; and quantity thinnings meant to result in the maximum production of wood fibre per acre per annum.

If left alone, a dense thicket grows but slowly, the food being subdivided among a large number of messmates. Toward the beginning of forestry, sylvienlturists were satisfied with "burying the dead and moribund poles." Later on, thinnings were extended into the suppressed elasses. The European experiment stations are now deeply engaged in working out the "best" method of thinning. Obviously, no method can be best for all sorts of speeies and for all sorts of loeal conditions.

I. The German and Austrian experiment stations distinguish between:

Grade 1. Light thinnings, removing the dead or dying.

Grade 2. Moderate thinnings, removing the dead, dying and suppressed.

Grade 3. Heary thinnings, removing also the condominating trees, or such of them which are not absolutely essential for the maintenanee of the main leaf eanopy overhead.

Grade 4. Very strong thinnings, plaeing a limited number of dominating and predominating trees in a free position.

Results so far published allot the maximum volume production (exelusive of branches) per aere to Grade 3. All these four grades might be eharacterized as "thinnings from below" (Eelaireies par le bas).

II. The French sylviculturists are advocating, on the other hand, "thinnings from above" (Eelaireies par le liaut).

The Frenchmen, as a matter of principle, leave alone the suppressed lower stems, proteeting by them the quality of the soil as well as the elearness of boles within the predestined elass. In addition, they relieve the tension, friction and struggle for food amongst the dominators by eulling out the worst developed dominators, or a percentage of those dominators whieh stand too elose together, and which have, eonsequently, one-sided erowns.

The objection to the Freneh method lies in the following points:

a. Material without inerement is left on the ground.

b. Weaklings and dying trees left inerease the dangers threatening the forest.

e. Greater diffieulty in marking trees to be remored.

However, where quality inerement is at stake, the Freneh method seems highly advisable. 


\section{AMERICAN S IL VICULTURE}

III. European opinions continue to differ widely with reference to the proper severity of thinnings.

After Martin, the thinnings must leave the sectional area of the forest constant by withdrawing, from a given age on, periodically the surplus of sectional area formed by gicwth.

After Schwappach and Wimmenauer, the normal yield of thinnings, expressed in per cent. of the final yield obtainable under a rotation of 100 years, should be for Beech and for Scotch Pine respectively:

Soil.

Beech after Schwappach.

Scotch Pine after

Best . .............

$147 \%$

Wimmenauer.

Medium . ..........

$137 \%$

Poor . . ............

$124 \%$

$181 \%$

$145 \%$

$115 \%$

After Fricke, the relative length of the crown and of the bole free from green limbs is the best criterion of thinnings properly made. At least 40 per cent. of the entire length of the tree should be clad in green limbs.

After Heck, no rule can be given the manner and the severity of a thinning depending on local and even personal factors ("liberty in thinnings"). To two trees being alike, a lack of a method is better than a method of thinning.

IV. Radically different from the systems of thinnings heretofore prevailing are the revolutionary views proffered by Borggreve. Borggreve thinnings interfere or remove none but the predominators and dominators-the biggest poles-closest to the best $\log$ size. Such thinnings begin but at the year sixty of a woodlot; they withdraw every ten years one-seventh of the stems which, being the largest, contain about one-quarter of the total volume.

Of course, high and early revenue is seeured by such practice. On the other hand, the trees removed are those growing at the best rate of interest. (From the sixtieth year on $90 \%$ of the annual accretion in a woodlot is supplied by the $40 \%$ [in number] of the largest trees).

The advisability of a Borggreve thinning largely depends on the reproductive power of a wood thus treated. In the case of Yellow Pine and on poor soil, the reproductive power of a wood seems too small to allow of a speedy repletion of the growing stock and of its leaf canopy. Nuch "food" goes to waste after Borggreve thinnings. In the ease of White Pine and Spruce, the danger 
from storm and sleet must be badly dreaded after Borggreve thinnings.

V. Wagener, at the year twenty-five of a forest, makes a thinning called "crown-isolation," surrounding the crown of each predestined tree with an air space two and one-half feet wide. The dominating trees left after the Wagener thinning should stand seven yards apart. Suppressed trees are not interfered with. Such cuttings are much heavier than Borggreve's. At the year twentyfive the bole of the dominators is not fully developed. The dominators left stand in an orchard-like position and show a very rapid diameter growth. Usually, but one $\log$ is expected to be obtained from the bole; it is obtained, however, within an extremely short rotation.

Obviously, for coniferous woods exposed to storm and of poor quality if wide ringed, the Wagener system is out of the question. The Wagener thinnings, unless they result in a heavy growth of adventitious branches, might be used to advantage for Black Walnut, Black Cherry and Oaks.

VI. American forestry has not had occasion to adopt a terminology descriptive of the various possible grades of thinnings. We might distinguish:

a. "Rectifications," correcting a previous negligence, to be subdivided as:

1. "Burials," removing the dead and the dying.

2. "Rescues," meant to save from death some valuable messmates.

3. "Revivals," reviving a stand which has been kept overstocked.

b. "Anticipations," anticipating the possibility of future crowding, to be subdivided as:

1. "Incitements," when the growth is to be incited particularly.

2. "Interferences," when the completeness of the leaf-cover overhead is purposely destroyed.

3. "Isolations," when the crowns of the individual trees are purposely isolated.

VII. In mixed forests such species as reach maturity during the pole stage might be removed from a late-maturing remainder by way of thinnings; e. g., Locust and Sassafras from a pole wood of Yellow Poplar; Hickory when reaching spoke bolt size from a mixture with Oaks; Chestnut when reaching telephone pole size from a mixture witl Oaks, Black Gum and Yellow Poplar. 


\section{Paragraph LXIII. Pruning in seed forests.}

A. The object at stake might be:

I. Production of $\log$ s free from knots,-especially free from dead knots. Live or sound knots measuring one and one-quarter inches in diameter affect the lumber price but slightly. The prevention of dead knots is, therefore, most important. No topshoot is formed without side shoots, and no section of a tree bole is free from branches and free from branch knots. Hence the advisability of pruning the boles of such species which develop branches of large diameter and of great persistence when dead. Branches (excepting adventitious branches) invariably start from the central core.

II. Increased height growth.

III. The production of cylindrical boles of a large form figure (Pressler's law of bole formation). Obviously, objects "II" and "III" are not obtained but by the removal of living branches.

IV. The reduction of the shade falling on a young, promising undergrowth.

T. The reduction of danger from fire in coniferous woods close to public roads.

B. Species: Hardwoods suffer less from the removal of green branches than softwoods. Green branches of over five inches in diameter should not be removed at all, except in case "IV." owing to the certainty of subsequent disease.

Oak heals best of all kinds the wound inflicted by pruning; Ash is likely to split; Maple is slow in closing a wound; Birch soon shows discase; Yellow Pine covers the wound quickly with rosin.

\section{Actual European practice:}

The practice restricts pruning to the object given under A. I., and within that limit to:

I. Dead branches.

II. Polewoods forty years to sixty years old.

III. Two log lengths from the ground.

IV. The specimens presumably predestined to reach the end of the rotation.

Pruning extends to a height reaching up to forty feet, is done by help of ladders, of a climbing apparatus (not climbing irons) or of saws attached to very long poles. The best saw is the "Alers" construction.

In France, sharp, curved blades are preferred to saws, since they produce a smoother cut. 
The branch is cut off as close to the bole as possible. Large branches are cut off in sections to prevent the bole from being scarred. In the case of broad-leafed species and in the case of live branches, large wounds are always tarred. Tarring in spring is impossible.

Expense at Biltmore for pruming Yellow Pine to a height of sixteen feet is two cents per tree.

The best months for pruning are the months at which the sap is down.

The advisability of pruning depends largely on the prospective price-difference between clear lumber and knotty lumber.

Pruning at a late date, say twenty years before cutting, is of no use. Theoretically it is best to remove dead branches in the vear of their death.

Where pruming is practiced, natural pruning produced by dense planting and hence dense planting itself might be spared, a proposition which cannot be indorsed generally.

Professor Knapp, Eric Forest School, urges the removal of side buds (notably for White Pine) and of young side shoots.

Literature: Translation of DeCowral by Nassachusetts Forestry Association.

\section{Paragraph LXIV. Underplanting in seed forests.}

An upper story of high forest might be undernlanted during the pole stage either artificially or by natural seed regeneration. In the latter case, weed species may answer the purpose. Underplanting may improve the timber quality of the upper growth. It usually does improve the productiveness of the soil.

Frequently the purpose at stake in underplanting is that of fully utilizing the productive capacity of the soil and of the atmosphere at a time when it is not entirely used by the upper story of growth. In that case, underplanting camnot be considered as a method of forest pedagogie.

A. The species to be underplanted are, notably, light demanders; for instance, Yellow Pines; Oaks; Hickories; Larches; Yellow Poplar, ete. In the primeval woods, Long-leaf Pine, Yellow Pine, Yellow Poplar, etc., show a natural undergrowth.

In practice, the wood to be underplanted is ferty to sixty years old. Heary "thinnings from below" precede underplanting. 
B. The species used for artificial underplanting are shade bearers and, if possible, soil improvers, notably Beech, Hard Maple, Fir, Lawson's Cypress, White Pine, Chestnut, Hemlock, etc.

Spruce is now disliked for underplanting, since it affects the growth of the upper story unfavorably. Seedlings one or two years old are commonly used for underplanting. Dogwood, Black Gum, Witch Hazel, Chinquapin, Witch Hopple, possibly Kalmia and Rhododendron might be used for underplanting where mere soil protection is desired.

The primeval hardwoods of the Alleghanies are frequently and densely underplanted with a low jungle formed by Ericaceae.

\section{Paragraph LXV. Key to the forms of seed for- ests.}

That general condition of a forest is termed its "sylvic form" which is brought about by its type or types of past regeneration, hence by its display of age classes and by the arrangement of the species exhibited.

The treatment allotted to the "form" by the forester, provided that it is a systematic treatment, is termed its "sylvicultural system."

The multitude of forms found in primeval nature is innumerable, since the "molds" from which the forms are cast, vary indefinitely with every wrinkle of the topography and every variation of the climate.

Man's interference has tended-at least temporarily-to further increase the multitude of forms.

It is a hard task to differentiate amongst this huge collection of forms and to arrange the collection into "orders," "families," "genera" and "species" composing it.

A priori, two great groups of forms might be singled out, namely, "primeval forms" the product of unbiased nature and "second grouth forms" the product of nature influenced by man's interference. This human interference might have been of a character utterly disregarding sylvicultural ends ("culled forms"); or human art might have tried, successfully or unsuccessfully, to lend a helping hand ("cultured forms").

The manner in which the various age classes of the forest are mixed within the "orders of forms" is of paramount interest. On this manner of mixing depend:

I. The manner and the possibility of remunerative lumbering. 


\section{THE ART OF THE SECOND GROWTH}

II. The type and the expense of regeneration and pedagogie.

III. The dangers from insects, fungi, fire, storm, etc, threatening the forest.

The functions of the mixture are so all-important in forestry, that the synthesis of the age-classes must serve as a main criterion in the construction of a key to the sylvicultural forms.

It must not be forgotten, however, that age differences of, say, twenty years are very conspicuous during the seedling, sapling and pole stage of the forest; whilst the keenest eye cannot detect these same differences in a forest of veterans.

In forests exhibiting a large variety of speeies the analysis of the form presents particular difficulties. Such is the case by far more frequently in primeval than in culled or eultured high forest. Sometimes a distinct form of a minor, scattering species appears to be "grafted" upon a distinct form of one or several major, gregarious species ("grafted forms"). Where two distinct forms in mixture occupy more equal shares (not minor and major shares) in the aggregate display, we may speak of "vedded forms." "Husband and wife, though distinct individuals, unite on equal terms for a life in a household of their own."

\section{Synopsis of "Forms of Seed Forests."}

A. Primeval forms of seed forests.
a. Primeval selection form.
b. Primeval group form.
1. paucivendible
c. Primeval compartment form.
2. multivendible
d. Primeval standard form.
3. omnirendible

B. Culled forms of seed forests.
a. Culled selection form.
b. Culled group form.
1. axe culled
c. Culled compartment form.
d. Culled standard form.
2. fire culled

C. Cultured forms of seed forests.

a. Even-aged main forms, emanating from
1. cleared compartment type of $\mathbf{n}$. s. $r$.
2. short time shelter wood compartment type of n. s. r.
3. planting
4. underplanting

- b. Uneven-aged main forms, emanating from

5. long time shelter wood compartment type of $n$. s. r.

6. strip type of n. s. r.

7. group type of $n$. s. r.

8. selection type of n. s. r.

c. Auxiliary forms.

9. standard form

10. two storied seed forest. 


\section{A. Primeval forms of seed forests.}

I. Characteristic for all primeval forms is a relative preponderance of the hypermature age-classes (veterans); a relative deficiency of the youngest age-classes (seedlings, saplings and poles); the presence of a large number of dead, decaying or unsound specimens only temporarily excelled in the "culled forms;" a large number of dead corpses of trees spread flat on the ground; irregular confines of the parts composing the aggregates; irregular composition of such parts by age-classes and species, many of which may be weeds; usually a heary layer of humus on the ground; usually the presence of a few strikingly large and spotless trees overtowering their neighbors; absolute lack of permanent means of transportation.

\section{Subdivision of primeval forms of seed forests.}

According to the relative share held by species of "weed trees" in the mixture of species composing them, the primeval forests might be subdivided into panci- multi-, and omnivendible forests. Primeral woods, in which but $10 \%$ of the timber species command a value, might be called "pancivendible"; at $50 \%$, the term "multivendible" and at approximately $100 \%$, the term "omnivendible" might be applied.

The vendibility of the members composing the forest, whilst it controls the possibility and the manner of its sylvicultural management, does not influence in the slightest degrce the actual original display of the forest.

It will be best, consequently, to subjoin the viewpoint of vendibility to the viewpoint of actual composition of the forest as displayed in the size of its composing parts-notably of its ageclasses.

Thus we arrive at:

a. A selection form, where the age-classes raised are mixed by trees or small patehes-a very uneven-aged form;

b. A group form, where the age-classes raised are segregated in groups oceupying from one-tenth to four acres;

c. A compartment form, where the age-classes raised are segregated in large, coherent areas (coves, slopes) covering from twenty to one lundred acres-a very even-aged form of forest.

The cpideta "paucivendible," "multivendible" and "omnivendible" added to the terms "selection form," "group form " and "compartment form" readily explain, in crude lines, the sylvicultural as well as the economic display of a primeval forest.

The groups or the compartments often show a sprinkling of 
huge trees known as "standards" or "reserves"-the latter term is used by H. S. Graves-having a much higher age and frequently belonging to a species different from that or those forming the main growing stock. Instances are:

Yellow Poplar stándards in Beech compartments;

White Pine standards in Balsam compartments;

Douglas Fir standards in compartments of Sitka Spruce;

Yellow Pine standards in Oak groups;

Cuban Pine standards in Cuban Pine groups;

Long-leaf Pine standards in Cuban Pine groups.

Naturally, where the standards belong to several age-classes and do not form a distinct age-class by themselves, we merely meet a selection form.

Standards in primeval woods are frequent enough to call for the singling out of a forrth form, namely:

d. A standard form, which might be again subdivided into:

A form of standards (reserves) over groups;

A form of standards (reserves) over compartments.

A variety of the latter subform found in the Chaparal thickets of California and in the Calmia thickets of North Carolina might be termed "form of standards over pancivendible compartments."

The two-storied seed forest is often formed by two or more distinct species appearing in distinct forms. It had better be considered as a combination of forms, one form being grafted upon another (e. g., compartments of Douglas Fir grafted upon the selection form of Hemlock); or one form being wedded to another (e. g., group form of Long-leaf Pine wedded with compartments of Black Jack Oak).

The term "two-storied seed forest" properly applies to a permanent combination of two distinct tiers of trees (representing one or more species), each tier emanating from regeneration by the compartment type of $n$. s. $r$. It is a compartment form wedded to a compartment form, never found in primeval nature.

\section{Treatment of primeval forests:}

The only treatment required is of a protective, not of a strictly sylvicultural character.

As long as the forest retains its primeval display, unhampered by human interference, the regeneration of the primeval selection form is of the cleared, shelterwood or advance growth selection type; the regeneration of the primeval group form is of the cleared or advance growth group type; and the regeneration of the primeval compartment form is usually of the cleared compartment type. 
Obvionsly, with the beginning of logging operations the "primeval forms" are gradually, piece by piece, changed into "culled forms," the display of which largely depends on rendibility and on fires.

The cases are rare in which the primeval forest enters at once or directly into a cultured form (Pisgah Forest of the Biltmore Estate; Ne-ha-sa-ne park; govermment forests in Galizia) without passing through the stage of "culled form." In the large majority of cases, the primeval woods pass through "culled forms" into "cultured forms," in the course of generations of men and of trees.

\section{B. Culled forms of seed forests:}

I. Characteristic for the culled forms of the seed forests is the absence of mature or maturing trees belonging to a desirable species; the preponderance of weeds, unsound trees, undesirable species and of trees and poles badly crippled by the logging operations. Only diseased trees or relative small trees of the desirable species are left to seed the ground.

Advance growth is invariably spoiled where the form is omnivendible or multivendible.

Characteristic for the culled forms is, further, the presence of large amounts of debris and of a parched humus, or else of the ashes thereof.

As a rule, the culled forms show death and scars due to forest fires.

Frequently, the culled forest displays an entirely new assortment of the species composing it, the previously prevailing species having been removed by logging. It is more "mobbish" than the primeval forest.

II. Subdivisions of the culled forms of seed forests:

The culled forest is usually more uniform than the primeval forest from which it emanates, owing to the uniform character of the logging operations. Still, the compartment form, group form and selection form originally exhibited are usually retained.

In the compartment form and in the group form a few worthless trees or veterans left standing and continuing to live frequently recall the "form of standards in high forest" or the "form of underplanted high forest." (Compare C, II, b, of the same paragraph.)

\section{Treatment of the culled seed forests:}

Where fires are kept out, the chances for seed regeneration are good-unusually good-owing to the condition of the seed-bed and to the unlimited food supply available for the seedlings. 
In the case of Yellow Pines, light fires seem even helpful to n. s. r.

Since the valuable species form, however, the minority amongst the seed-trees, the worthless and less valuable kinds usually prevail in the young growth formed after culling. Cleaning and weeding are required to improve the prospects of the minority composed of noble species. Besides, improvement cuttings are indicated in the culled forms: "The culled form is the form requiring improvement cuttings."

The "aristocrats" removed by the axe return frequently after a score or two of years, the rash "mob" then acting as nurse-trees or as ushers.

Where heavy and extensive fires have swept the culled forest originally consisting of exacting species, patient waiting alone can secure conditions more favorable to aristocratic regeneration. Fires frequently convert a seed forest of hardwoods into a sprout forest.

The younger age-classes suffer more from fire than the older age-classes. A fire-swept, culled forest is deficient, at least temporarily, in seedlings, saplings and small poles. A few years after a fire, the culled forest often displays the features of the underplanted form of high forest (Par. LXV. C. II. b.) or of the composite forest (Par. LXXIII).

\section{Cultured forms of seed forests:}

I. Characteristic for the cultured forms of the seed forests is great uniformity; lack of hypermature, unsound and misshapen aristocrats; lack of weed-trees; lack of coppice shoots; complete cover overhead; multi- or omni-vendibility; permanent means of transportation.

The cultured forest does not require weeding or improvement cuttings for the reason that cleanings and early thinnings have prevented the development of weed-trees and wolf-trees, whilst the hypermature veteran has been removed long ago.

If the culled form is "the form of improvement cuttings," the cultured form might be termed "the form of thinnings."

\section{Subdivision of cultured seed forests:}

a. Main cultured forms of seed forests:

1. Even-aged cultured forms, when the age-classes mixed within a compartment differ by not to exceed twenty-five years.

aa. Form emanating from the cleared compartment type of n. s. r.

bb. Form emanating from the short-time shelterwood compartment type of n. s. r., the periods of regeneration not exceeding twenty-five years. 
ce. Form raised by planting seeds or seedlings over whole compartments.

dd. Form raised by unlerplanting seeds or seedlings over whole compartments, followed by (gradual) removal of the superstructing trees within less than twenty-five years.

2. Uneven-aged cultured forms, when the age-classes mixed within a compartment differ by over twenty-five years.

aa. Form emanating from the long-time shelterwood compartment type of $n$. s. $r$.

bb. Form emanating from strip types, either restocked by n. s. r. or by planting.

ce. Form emanating from group types of n. s. r., or from planted groups.

dd. Form emanating from selection types of n. s. $r$.

b. Auxiliary cultured forms of sced forest:

aa. Form of standards in seed forest, when a limited number of trees are left to grow amongst and with the young growth for a longer or shorter number of years.

The standards might be left either in scattering groups or individually seattered over the seeond growth. In the latter case, none but storm-firm species will answer. It is wise to leave the standards in the proximity of roads so as to allow their removal without inflieting damage on the young growth. Species well adapted for standards are: Yellow Pines, Larches, White Oaks, Yellow Poplar, Black Locust, Hickory, Walnut, Black Cherry. Shade-bearers and flat-rooted species will not answer the purpose.

It is unwise to leave standards unprepared by the preceding cuttings for the life in the open. Standards set suddenly free will cover themselves rapidly with adventitious branches, will grow stagheaded, will suffer from storm and sleet, and will die without yielding the results for which they were left.

Where the standards shade the young growth too badly, it may be necessary to remove their lower live branches.

The number of standards left per acre does not usually exceed twenty-five. Very good soil and short rotations allow of an increased number. Standards may be, but need not be, of the same species which forms the undergrowth.

Where the standards do not belong, approximately, to one and the same age-class, there the standard form bastardizes with the uneven-aged forms emanating from the group-type or from the selection type of n. s. r.

bb. Form of two-storied sced forest, when an upper and a lower leaf eanopy is maintained in distinctly separate tiers. 
Species adapted to form the lower leaf canopy are; Beech, Hard Maple, Black Gum, Firs, Hemlocks. The species in the upper story liad better have a light-demanding character. The form is created by raising a polewood (even-aged) of Yellow Pine, Oak, Hickory, Larch, etc.; by early and heavy thinnings from below; by very heavy thinnings after the completion of the principal height growth (year forty to sixty); and by planting at the same time either seeds or preferably seedlings of shade-bearing species. Should the undergrowth catch up with the upper growth, either the one or the other must be removed. The undergrowth preserves the fertility of the soil by thorough shading, by the formation of a mixed humus and by increased leaf-fall. It improves the bolequality of the upper growth, the crowns of the lower growth holding the boles of the upper in close embrace. In addition, it prevents any part of the timber-producing factors of the localicy (atmosplere, light, moisture, soil) from lying unutilized. Usually the undergrowth produces firewood, the upper growth timber.

The so-called "Seebach's modified high forest" has Beech in the upper as well as in the lower story. The lower story is obtained from self-sown seed of the upper story atter very heavy thinning. Under and upper growth are finally utilized in the same year or in the same period of years.

III. Treatment of cultured seed forests.

Regeneration in the cultured form of seed forest takes place in any of the types of n. s. r., or by planting seeds and seedlings. As a rule, natural regeneration is now combined with partial planting. Cleaning and thinning are usually indicated, whilst, as stated, weeding and improvement cutting are not required.

\section{Paragraph LXVI. Critical remarks on the forms of seed forests.}

\section{A. Attitude of the investor:}

It is almost amusing to observe the difference of attitudes which the statesman, the lumberman and the forester show with respect to the terms "primeval," "culled" and "cultured" forests.

Still, all of these forests are justifiable, at least temporarily, and usually justified by the economic conditions evolving them.

I. The primeval forest seems to be the "forest in economic stagnation." Its production is no greater than that of barrens; it is nil. Still, fortunes have been made by many investors, 
buying and retaining primeval forests for their own benefit and incidentally for the benefit of later generations of men. With every parcel of primeval forest destroyed, the value of the balance left increases in estimation and in actual usefulness.

Sylviculturally, no forest requires a more minute and more painstaking treatment than the primeval forest, when its conversion into a cultured forest is at stake. Still, the small price obtainable for its products defies any attempt at a remunerative outcome of heary sylvicultural outlays. What is the use of safeguarding or producing a second growth, by sylvicultural acts, which is devoid of any prospective value, or which is of a value inferior to the expense required to safeguard it or to produce it?

Thus, sylviculturally as well as financially it seems very frequently best to leave the primeval wood unattended, unregenerated, unconverted, for the time being.

When the average acre of primeval forest commands, in a given locality, a price of $\$ 100$ or more, its owner can begin to consider the advisability of logging it with a view to relogging it.

Where the value of the preceding growth is at its best, the art of the second growth is at its best also.

Where the ent of the mature stands yields hundreds of dollars per acre, the owner is wilung to set aside from ten to twenty dollars per acre, investing them in a second growth.

Is it not insane to expect an owner to convert a first growth worth but twenty dollars per aere into a second growth at an expense of twenty dollars per acre?

The outsider urges the timberman to do what he would never do himself: To exchange a steer for a calf.

II. The culled forest usually exists in localities where timber has a higher value than in the primeral backwoods.

Indeed, where the culling of the forest has made great progress in a state or in a county, there the culled forest is getting rapidly ripe for sylvicultural treatment.

Heavy culling merely proves a high range of stumpage prices, fostered by a near-by market and by good means of transportation.

Where the forest has bcen culled only of decidedly mature trees, there the chances for geod results are bright, financially as well as sylviculturally.

The attitude which the owner of culled forests adopts towards sylvicultural investments, necessarily depends on a diagnosis of the future of the lumber industry appealing to him. 
III. The cultured forest is still a rarity in the United States, and will contimue to be a rarity during our lifetime.

Imagine for a moment, that the famous Black forest of Germany were suddenly transferred, with its fine Spruce woods, its splendid roads and its skilled laborers, into the heart of the Adirondacks! Would it be wise, financially, to continue its sylvicultural treatment as inaugurated in Germany?

It certainly would; the $\log s$ salable in the Black Forest are also salable in the Adirondacks at a good profit. And a network of splendia roads would tend to cheapen transportation by exactly that many cents per standard, which the stumpage itself would gain per standard.

On the other hand, that same Black Forest transferred to the Pacific coast-say into the Olympic mountains-would certainly prove a financial and therefore a sylvicultural failure.

The better it pays to cull the forest, the closer at hand is the time of the cultured forest.

It must be kept in mind, however, that the change from the culled to the cultured forest requires, aside from a market for the products obtained and from the willingness of the owner to embark in sylvicultural investments

a. Investments in permanent means of transportation;

b. Relative safety from forest fires;

c. Time.

Wherever the woods emerge in a decrepit condition from the primeval stage after reckless lumbering, heavy fires, unlimited Fasturage, there the adoption of a system will be found necessary after scores of years breaking entirely with the past and raising, after thorough destruction of the past growth, by artificial means a new crop of valuable species.

Large, continuous elearings badly resist reforestation; they behave, in this respect, like the prairies, although on a smaller scale. Extensive, even-aged woods form "incubators" for disastrous diseases; suffer from snow, storm, drought, and frost. On the other hand, their management is greatly facilitated, so that reinforeing, cleaning, thinning, regeneration and utilization are much cheapened.

\section{B. Selection of form by the forester.}

I. The primeval forms of seed forest found by the forester usually appear unretainable. Whatever the case be, the first stroke of the axe is sure to remove the mature and hypermature trees, the preponderance of which belongs to the character of any primeval form. 
However, when transforming primeval woods into cultured woods, the forester should endeavor to retain as much as possible the form originally sanctioned by nature. Such retention is the safest way to sylvicultural success. Still, it usually necessitates heavy investments for permanent means of transportation, and where the owner is unwilling to make them, euttings by compartments or by strips are required, which in turn lead to the adoption of the advance growth type, shelterwood type, or cleared type of n. s. r.

'he strip form, as mentioned elsewhere, seems to be particularly well adapted to meet American needs.

II. The culled forms of seed forest must be retained by linc forester in the compartment, group or selection form first encountered, unless the culling has been particularly light. Improre. ment cuttings are not apt to change the form of the forest. Whise artificial reinforeing is resorted to, the forest will gradually develop even-aged forms. When after heavy eulling the average growing stock per acre is badly reduced, forms allowing of short rotations are indicated, so especially selection forms and standard forms. Frequently in such cases, the high forest is abandoned, and the sprout forest is resorted to.

III. In the cultured forms, the trend of the times favors unevenaged forms, notably mixed group forms and narrow strip forms. on account of greater safety.

Heavy "thinnings from above" are in vogue, frequently in connection with underplanting (or underseeding by n. s. r.).

Regeneration is effected either by planting compartments, strips and groups, with or without a shelterwood overhead, or Li' the various types of $n$. s. r.

Where the deficiency of the growing stock leads to the adoption of short rotations, standard forms, two-storied forms, underplanted forms or coppice-under-standard forms must be resorted to. In the latter case, of course, the nigh forest form is thrown overboarl.

\section{Paragraph LXVII. Seed forest by species.}

A. Oaks: The Oaks appear in pure stands but rarely.

I. Primeval woods. The primeval seed forest exhibits the Oak:

a. As the lower story planted in groups or compartments underneath an upper story of Long-leat Pine, Loblolly Pine, Short-leaf Pine; 
b. In small pure groups sprinkled amongst the Bald Cypress and Red Gum of the southern hummocks;

c. In the selection form grafted upon compartments of high forest of other hardwoods, notably of Chestnut, Hickory, Gum (Ten.); or grafted on compartments of Kalmia, Rhododendron, Chinquapin (N. C.).

d. In pure even-aged groups (prairie border's).

e. In selection forests mixed with many other hardwoods also in selection form.

II. Culled seed forests: The culled forest of oak is usually axe-culled as well as fire-culled, thus partly losing its character as a high forest.

The n. s. r. of White Oak, Chestnut Oak and Searlet Oak at Biltmore proceeds selectionwise or in compartments, notably so on Indian fields in the Pink-beds; underneath Chestnut, Maples, and Oaks on Poplar hill; mixed with Hickory on the lower west slope of Averys creek and so on.

'The Oaks endure shade well for a long number of years, trailing on the ground until freed from superstructure. Coccinea three years old is only five inches high, being clipped back continnously by insufficient lignification of its top-shoots.

Even-aged polewoods of Oak are found all over the Blue Ridge and the Piedmont Plateau. Examination will usually prove them to be fire-culled coppice formed by the fire-killed, younger age elasses of primeval woods (seedlings, saplings and small poles).

\section{Cultured seed forests.}

The cultured high forest of Oaks in America is still in statu nascendi. The growth of the Oaks during early youth is very slow. The soil to be used for it is usually so badly hardened as to require artificial help to n. s. r. Oak seedlings and saplings are rare in Pisgah Forest.

The Oaks mingle with the Short-leaf Pine everywhere as an undergrowth started by n. s. r., or as a companion-growth in Pine polewoods. Here too, however, the fires have usually converted seedlings and saplings into stump sprouts.

In the S. E., regeneration under shelterwood or in advance of logging (by the group type or by the compartment type) seems advisable. In the mixture with the Oaks should be encouraged: Maples, Black Gums, Pines (White Pine retains its branches for a long time in the mixture), Chestnut; Hickory, Walnut.

Record of seed years at Biltmore:

White Oak: good in 1899. 
Post Oak: in 1900 the only mast-bearing oak.

Black Oak: splendid, full mast year in 1901 in all situations. Scarlet Oak: splendid, full mast year in 1901.

\section{B. Chestnuts:}

\section{Primeval Forests:}

Actually primeval forests of Chestnut seem very rare. The Chestnut woods of the Appalachians have been ransacked by fires for many decades of years. The n. s. r. seems to have been of the selection type. Chestmut seems to avoid limestone-soil and ceases to occur where limestone appears (Ky; Ten.).

\section{Culled seed forests:}

'The fire-culled forest shows an absolute lack of seedlings, saplings and poles.

The axe-culled forest consists merely of coppice.

Trees beset with dead branches are invariably wormy (Lymexylon).

Seed years seem to be getting scarce, possibly under the influence of fires, to judge from the reports of mountaineers. The old trees are frequently stagheaded and fail to successfully regenerate their kind.

Seedlings one year old are about eight inches high, when found in the woods. They appear individually scattering and not in groups.

\section{Cultured seed forests:}

The cultured forest usually has the form of coppice or coppice. under-standards. Plantations in the Lnited States are made more for fruit-growing than for timber-growing. The abandoned fields at Biltmore seem too dry for successful development. Chestmuts planted as an undergrowth below Oak and Pine have done poorly, owing to the ravages of squirrels.

The poles and trees seem to badly resent any sudden interference with the leaf canopy and with the humus.

Thinnings and cuttings in the shelterwood system should be light.

The competition of stoolshoots invariably formed after cuttings reduces the prospects of seedlings simultaneously obtained. Stoo:shoots cannot be entirely prevented by deadening previous to cutting.

Chestnut produces a splendid humis and is an excellent companion for Oaks, Hickories, Walnut, Black Cherry, Ash and Yellow Poplar; also for White Pine and Hemlock. It regenerates in 
mixture with Yellow Poplar on small abandoned fields of Pisgah Forest to a limited degree.

On the mountain tops, where Chestnut stands in an orchard-like position, seed occurs anmually. Full mast years are rare.

\section{Hickories:}

I. Primeval forest: The Hickories appear regenerated in the selection type and in the group type.

II. Culled seed torest: The Hickories suffer badly from fires. Fires do not kill the poles, but cause the butts to burst subjecting them to decay. Weeding and heavy improvement cuttings ars beneficial.

\section{Cultured seed forest:}

From the early pole stage on, the crowns should be placed in a free position so as to cause the formation of wide rings.

At Biltmore, the boles are apt to be very branchy, the tough limbs being very persistent.

In the mountains, on stronger soil, the boles clear themselves readily.

The Hickories regenerate by n. s. r. in abandoned fields in mixture with Black Gum. Sassafras, Yellow Poplar, Locust, Oaks, etc.

In the plantations on abandoned fields at Biltmore, Bitternut alone promises to be successful. The other species are badly handicapped by rodents and seem to be of very slow growth.

The Hickories seem to be immune from damage by frost in their native country; not so in Germany.

Full seed years are not of record.

\section{Walnuts :}

\section{Primeval forests:}

The walnuts appear in the primeval woods invariably in mixture with other species, on strong soil, seemingly regenerated by the selection type.

\section{Culled seed forests:}

The walnuts seem remarkably fireproof from the early pole stage on. Seed regeneration is rare in the woods, but more frequent on old deadenings close to habitations, where the squirrels were held in check.

\section{Cultured seed forests:}

Without artıficial help, n. s. r. seems very problematic. Under any circumstances, the rodents must be kept off. 
Plantations are frequently found and do very well in early youth, unless the soil is badly hardened and impoverished. The stands should be dense, whether pure or mixed with Oaks etc., so as to produce clean boles. Plantations seem to fail in the close proximity of old trees.

The plantations at Biltmore have failed invariably in the woods, owing to the ravages of squirrels; toungya on leased farms shows poor success, owing to the unreliability of the lessees; plantations of seedlings three years old failed badly; plantations of yearlings freeze to the ground annually on all slopes; plantations of nuts on small fields have done very well, where the ground was good; and the change from good to bad, brought about by the undulations of the soil, is very marked. Failures on poor soil are now doctored up by a nursegrowth of Yellow Pines, - a remedy promising some success.

\section{E. Beech:}

I. The primeval forest exhibits the compartment, group and selection type of n. s. r. The humus is usually very heavy and so moist that fires have a poor chance to spread. In the South, at lower altitudes, Beech merely fringes the river banks.

II. The culled seed forest shows many root suckers (Appalachians) and stump sprouts, stumps three feet ligh forming the sprouts on the top of the stump.

In the Blue Grass Region, huge park trees are frequently foun 1 in a dense undergrowth of seedlings and saplings. Here the more valuable species have been culled out many years ago, and the Beech is left in exclusive possession of the soil.

III. The cultured seed forests of Beech are easily regenerated in the shelterwood-compartment type. The selection type yields branchy boles. Beech is the best companion imaginable for fastergrowing species; is splendidly qualified for an underwood planted beneath aristocratic species; is exacting and sensitive.

Plantations on abandoned fields are out of the question, except at high altitudes.

In Michigan, the fall of 1911 produced a full mast of beechnuts.

\section{F. Basswood:}

\section{Primeval forests:}

In the Lake States and in the alleghanies, Basswood exhibits the form emanating from the selection type of n. s. r., grafted on the compartment type of White Pine, or of Hard Maple, or 


\section{THE ART OF THE SECOND GROWTH}

else mixed with Hard Maple, Elm, Chestnut, Red Oak, Yellow Poplar.

\section{Culled seed forests:}

The regeneration follows the selection type; fires elip the seedlings and saplings; larger poles and trees seem to withstand well.

\section{Cultured seed forests:}

Young seedlings develop very slowly; they are less sensitive than their shade-endirance would indicate. Pnre forests are found only in Russia.

Seedlings planted at Biltmore on old fields, of strong qualities, have hesitated to develop for six years, growing bushy and erooked.

Linden underplanted below Oaks and Chestnuts after moderate thinning on North slopes seems to answer admirably, forming long and straight, although overhanging topshoots.

Seed occurs in Pisgah Forest annually. The majority of the seeds, however, seem to drop immature.

\section{G. Yellow Poplar:}

\section{Primeval forests:}

Yellow Poplar appears invariably in the selection type, or iu the form of standards.

\section{Culled seed forests:}

The species attempts unceasingly to propagate its kind by n. s. r. The heavier the destruction by the axe, the better are its chances for success. Fires, on the other hand, annihilate the seedlings and check the chances for regeneration thereafter, owing to a rank growth of weeds following the fires. In Pisgah Forest, seedlings and saplings were entirely lacking, until fires were stopped.

The regeneration on old fields, on the other hand, is prolific and easy. Cattle press the seeds into the ground and check the competing weeds. Sassafras, Locust and Pine frequently act as ushers. The old fields are usnally protected from fire by the owners wishing to protect their fences.

No known species prunes itself so readily from branches as does Yellow Poplar, the dead branches popping off without leaving any stumps.

\section{Cultured seed forests:}

No species at Biltmore is as easily regenerated by n. s. r. as is Yellow Poplar. In Biltmore Forest, the group type is readily carried through with the help of three or four mother-trees to the acre. The companions of the mother trees, notably Oaks 
and Chestnuts, are gradually eut away; spreading Dogwoods are deadened to prerent them from forming stoolshoots.

In Pisgah Forest, regeneration is helped by preceding pasturage (especially in early spring, before the seeds of Poplar germinate), and by weeding following in the wake of n. s. r.

The seeds will never sprout in the humus; seedlings born late in spring (June) and showing the cotyledons still in September are sure to be killed by frost; also seedlings growing in the shade of weeds. The logging roads and $\log$ yards are real "nurseries" for Poplar. On steep ground, the seedlings are washed out by the rain.

The growth is very fast.

Seed years are annual; hollow trees are likely to furnish poor seeds.

Plantations of three-year-olds at Biltmore on poor old fields did badly; on good soil, especially where a volunteer growth of Locust has joined the plants, the success is complete. Plantations of Yellow Poplar alternating with White Pine promise well.

\section{H. Maples:}

\section{Primeval forests:}

Here the regeneration follows the compartment type (Adirondacks, Missomri valley), the group type and the selection type (Michigan, Northern Minnesota). Maple usually appears in mixture with other lardwoods, also with Spruce and White Pine. Soft Maple occurs in low, moist sites as well as on dry ridges. Hard Maple demands well-drained and strong soil, preferring Northern aspects.

\section{H. Culled seed forests:}

After culling, the younger stages of Maple are usually left in possession and develop in dense thickets, preventing more valuable species (White Pines) from establishing themselves. In the Adirondacks, Soft Maple is frequently found on Spruce flats after windfalls (associated with Yellow Bireh).

\section{Cultured seed forests:}

Dr. Fernow at Axton succeeded in establishing, in places, a splendid regeneration obtained from advance growth $n$. $s$. r. of the compartment type, removing the parents at one stroke. In Europe, the shelterwood compartment type answers admirably.

Biltmore Forest is deficient in Maple. Still, Hard Maple planted on abandoned fields, pure or in mixture witl White Pine, has done almirably, except on dry S. W. slopes, dry spurs, and very moist river bottoms. 
In Pisgah Forest, Red Maple usually appears as a weed overshadowing aristocratic seedlings.

The best Maple forests of the world are those of the lower peninsula of Michigan. Here, old deadenings abandoned some forty years ago, and old windfalls at the edge of elearings show a natural second growth so luxurious, straight, dense and perfect that little remains for the forester to improve.

Where a light ground-fire has destroyed a superabundance of leafmold earpeting the ground, the regeneration of Sugar Maple is prolific after sced-years such as autumn 1909 in Michigan.

\section{Ashes:}

I. Primeval forests: The Ashes usually regenerate and stand in patches or groups, oceupying the moister sites.

\section{Culled seed forests:}

Protected by moist ground, the Ashes stand a good chance to escape the fires. During early youth, the seedlings endure remarkably heary shade. Weeding and improvement cuttings produce splendid results.

\section{Cultured seed forests:}

Regeneration in the group type is easy, if helped by cleaning (Ducker Mountain of Biltmore Estate) and gradual removal of the obstructing trees. On old fields, on moist slopes, White Ash is often accompanied by Yellow Poplar and Halesia.

Plantations of three-year-old Green Ash have failed utterly at Biltmore on dry, hard soil.

Plantations of three-year-old White Ash along the creeks do very well; also seed plantations on good soil in the gaps of a ridge.

The early growth is very fast.

Seeds are profusely produced from the pole stage on.

\section{J. Red Spruce:}

I. Primeval forests: The primeval Spruce woods appear as more or less even-aged compartments in the swamps and sloughs of the Lake States and on the dry, shallow South slopes of New England; in the eleared group form and in the selection form in Western N. C. at altitudes exceeding 5,000 feet, mixed with Abies fraseri (selection); in the seleetion form, grafted upon compartments of Beech and Maple, on the hardwood slopes of the Adirondacks. In the latter case, Spruce never regenerates in the heary layer of broad-leafed humus, but selects invariably the half-rotted corpse of a dead tree (Hemlock) for a seed-bed. 
II. Culled seed forests: In slightly culled forests immune from fires, Red Spruce seems to reproduce with remarkable ease. On fired ground, Birches and Cottonwoods frequently act as ushers. Its persistence below an impenetrable leaf eanopy of Beech or Maple is surprising. Freed from superstructure, after long years of suffering, it answers the chance for rapid growth almost immediately.

III. Cultured seed forests: Spruce requires high atmospheric moisture; is satisfied with shallow soil; can be readily reproduced by $n$. s. r. as well as by planting.

Seed years: Prolific in North Carolina in fall 1901. The trees, top heavy with cones, were mowed down by storms.

\section{K. White Pine:}

I. Primeval forests: The White Pine of the primeval woods appears in compartments, almost even-aged, or in groups, either pure, or with an admixture of hard Maple, Linden, Elm, Yellow Birch; or in the form of standards over Red Spruce and Balsam; or in the selection form, as in the Calmia thickets of Pisgah Forest. It is flat-rooted, subject to windfalls, in the North not tolerant of shade.

II. Culled seed forest: The gorgeous White Pine forests of the Lake States, after culling followed by fires, are invariably surendered to a shrubbage of hardwoods. Second growth is found in beautiful groups underneath Norway Pine; individually sprinkled amongst Jack Pine, Basswood, Birch, etc.; also on old burns in extensive, even-aged compartments; along roads and at the edge of clearings; in New England on old fields.

In Western N. C., White Pine regenerates readily on broomsedge fields; in mixture with the Oaks on the uplands; in mixture with Red Maple and Red Birch in the river swamps, ete.

III. Cultured seed forests: At Biltmore, the n. s. r. of White Pine started by a few seed trees succeeds easily in the group type. White Pines planted under dense shelter soon require the help of the axe. Individual trees are very retentive of branches. Plantations on several hundred acres have done admirably. White Pine is the easiest Pine to plant on old fields, or in groups of the woods after clearing.

Seed years are frequent at Biltmore, recurring at intervals of two or three years. 


\section{Yellow Pines:}

1. Primeval forests: The pure group form (Black Hills) or the group form wedded with the compartment form of Oaks reaching a lesser leight than the Pines seem to be typical. Pine standards are often left. Pinus taeda, divaricata, and murrayana occur in even-aged compartments; P. palustris and P. heterophylla usually oceur in groups.

\section{Culled seed forests:}

The culled forest is usually visited by fires which gradually convert an undergrowth of hardwoods, where it exists, into coppice. Beneath Longleaf Pine, this undergrowth begins to sprout only at a time when the mature Pine is removed.

Where the pure high forest continues, fire has usually improved the chances for n. s. $x$. by preparing a ready seed-bed and by lessening the severity of future fires.

All Yellow Pines regenerate prolifically on abandoned fields, often in stands which artificial planting could not produce equally well.

\section{Cultured seed forests:}

The n. s. r. of P. echinata in the Biltmore woods ereates nuclei for small groups which are freed and gradually enlarged. Heavy thinnings, from the early thicket stage on, prevent crowding in the pole stage and thereby check the chances for successful attacks by the bark beetles. Pruning (dead branches only) 100 decidedly predestined trees per acre seems remunerative at Biltmore.

Standard form of $\mathrm{P}$. echinata seems indicated at Biltmore.

All Yellow Pines are easily planted when one or two years old and get along without cultivation in the absence of annual weeds. Heavy growth of weeds, on good soil, however, is sure to smother them.

In pure and large natural regenerations, it is wise to leave some hardwood standards with a view to securing an admixture of hardwood seedlings in due course of time.

In mixture with White Pine, Yellow Pine is soon subdued on good soil, while it retains the lead on poor soil.

Seed years of Pinus echinata occur at Biltmore every seven years. The fall of 1902 was a prolitic breeder of seeds even in polewoods thirty-five years old. 


\section{CHAPTER III \\ THE SPROUT FOREST}

\section{Paragraph LXVIII. Genesis of the sprout for- est and its types.}

The sprout forest is either the result of stump-shoots or is obtained from rootsuckers, layers and cuttings.

\section{A. Stumpsprouts (or stoolshoots or coppice shoots).}

I. Species: All hardwoods whilst young form stump shoots when eut just above the callus. Amongst the softwoods, the Sequoias exhibit enormous stump sprouts. Amongst the Yellow Pines, P. rigida and echinata, also P. taeda, are capable of developing sprouts from stumps measuring less than six inches in diameter. White Pines, Spruces, Firs, Larches, Hemlocks, etc., never form stump sprouts.

II. Diámeter: The sprouting capacity rapidly decreases, usually, with increasing diameter of the stump. The diameter at which the principal height growth is completed usually denotes the limit permissible for coppice rotations. This rule is particularly well illustrated by the behavior of Yellow Pine, Birch, Maple, Yellow Poplar, Oaks, Hickories, ete. Chestnut and Sequoia do not seem to follow the rule.

III. Soil: Good soil allows big stumps otherwise unproductive of sprouts to form stool shoots.

Good soil produces stronger, but less spronts than poor soil.

IV. Life of stumps: The life and hence the sprouting capacity of stumps repeatedly coppreed is elosely connected with the resistance offered by the timber to decay. White Oak, Chestnut, Sequoia and Locust are perseverant sprouters, the scars on the stump being protected from lotting by the antiseptic qualities of the substances incrustating the heart wood.

The reproductive power of Birch, Beech, and Maple is not sustained for a long time. Asl and Basswood show greater perseverance.

It might be said that a long-lived species is also a persererant sprouter.

The sprouting capacity is especially good in species capable of 
forming a separate and detached root system for the sprout independent from the mother stump. This is the case in species forming sprouts from the base of the.stump (at the root collar).

\section{Optimum number of stumps per acre:}

The optimum depends on the length of the rotation. It is considered to be: For German Oak coppice, rotation twenty years, 2,000 stumps per acre; for Osier culture, rotation one or two years, s0,000 stumps per acre.

VI. Manner of Coppicing: The use of the axe is preferable to that of the saw. Stumps should be as low as possible, to begin with. In case of stumps-notably Beech and Birch-coppiced a number of times it is better to cut in the new wood. The scar should allow the water to run off, instead of collecting it like a saucer. The expense of the genesis of the coppice forest is practically nil.

\section{Season of copprcing:}

If the wood must be peeled, the cut should be made in early spring. Late spring eutting subjects the new sprouts to early frosts. Coppicing in August is supposed-for similar reasons-to affect the vitality of the stumps. Where the shoots are not to be peeled, cutting in late winter is best. Winter cutting prevents the stumps from bleeding and allows to remove the product cut before the appearance of new shoots without injuring the stumps.

Cutting in fall subjects the stumps to frost-cracks and to barkblistering; it causes the new fleshy shoots to appear early in spring, at the season of prevailing late frosts.

Accessibility of the locality at the proposed season of cutting and availability of local labor further determine the season of entting.

VIII. Reinforcing: Where the number of stumps is or becomes deficient, there the owner may plant seedlings or stump-plants to replenish the growing stock.

B. Root suckers: Cottonwood, Willow, Locust, Alder, some Elms and Maples, after European experience Liriodendron, also Beech in the Southern Appalachians, form root suckers, especially on porous soil. The suckers are increased by locally uncovering the porous soil. They might be severed from the stump and planted when two or three years old; but this is expensive. Gardeners often use pieces of roots, say ten inches long and finger-thick, for propagating broad-leafed species in good soil. An observer in F. and J., May, 1904, claims to have found that Fir and Spruce in the Presidential Range of the White Mountains propagate their 
kind by the natural and unaided formation of suckers developing from long horizontal roots.

C. Layers: A low, long branch of a standing tree is partly buried in a trench one-half foot deep, held in place by hooks, pins or stones, the end of the branch protruding above ground. The branch thus embedcled forms roots and shoots. The latter are severed from each other a year or two before planting in the open.

Layering is a gardener's method only locally used in parks. At high altitudes, under the influence of very great atmospheric moisture, the low Spruce branches form roots and shoots in a similar manner.

D. Cuttings: Willows and Poplars are usually propagated by "cuttings," viz. by pieces of branches one foot long and two years old, tipped with a piece one year old. The cuttings are inserted obliquely, the tips barely showing above the ground. Planting dagger or turning plow are the tools used. Care must be taken to prevent the bark from peeling off. It is claimed that the constant use of cuttings causes a deterioration of growtl. Cuttings of sapling size taken from strong and long branches are also planted in good nursery soil for a number of years and planted in the open ground after catching root. Willows and Poplars allow of heavy trimming. Among conifers, only Sequoia permits the use of euttings. It is claimed that Sequoia-chips sprout successfully in the moist climate of the Coast Range.

\section{Paragraph LXIX. Pedagogie of the sprout forests.}

The spront forest is tended by cleaning, weeding, and thinning; also by improvement cuttings and pruning.

A. Cleanings: To prevent undesirable shoots from developing, the stumps producing them must be removed. Stumps of umdesirable species (Blackgum, Hazel, Alder) can be removed only by digging, or by heaping dirt upon them, or by firing heaps of debris placed on the stumps. Usually, it is preferable to deaden undesirable trees instead of trying to prevent their stumps from forming sprouts. In some species, stumps three feet high will form poor sprouts, a quality which might be taken advantage of.

B. Weedings: Misshapen trees or poles of a desirable hardwood species, cut level with the ground, will at once produce shoots of good quality. Poles badly damaged by fires should be eut for an 
increase in vitality. Trees left because worthless should be deadened, unless they belong to the aristocracy, or unless they improve the good sprouts as well as the soil in the role of subordinate companions.

C. Thinnings: Thimnings are rare in European coppice woods; in tanbark coppice they usually purport to improve the quality of the bark. Where nade, the thinnings usually remove the weaker shoots of a stump for the benefit of the better and stronger shoots. The rotations of European coppice being short, heavy thinnings tend to deteriorate the quality (branchiness and shape) of the shoots as well as of the soil; and light thinnings are rarely remunerative.

In America, coppice of Catalpa, of Chestnut, of Locust and Hickory may invite heavy thinnings where fence posts, telephone posts, railroad ties, wagonstock, etc., find a ready market.

In case of Hickory, thinnings periodically remoring the best trees (à la Borggreve) might seem indicated.

D. Improvement cuttings: Improvement cuttings are neces. sary in culled sprout forest emerging directly from primeval hardwood forest heavily cut or heavily fired. Such forest is invariably encumbered with bushy and worthless standards (if the standards have a value, the forest belongs to the form of coppice under stand. ards described in Par. LXXIII-Par. LXXVIII) interfering with the development of the shoots; or with undesirable species left by the logger. The mob frequently prevails over the aristocrats.

The first final cut at the end of the first coppice rotation usually answers the purpose of an improvement cutting.

E. Pruning: Pruning is required to prevent coppice of Catalpa, Locust and Ash from forming forks or heavy branches. Naturally, pruning is expensive and dangerous at the same time since live branches are removed. The danger is particularly great where the rotations are long, the pruned stump shoots being left for decades of years after pruning.

In the pollarding form, pruning or rather lopping obviously coinprises the harvest of the erop.

\section{Paragraph LXX. Key to the forms of sprout forests.}

Although coppicing is called a type of natural regeneration, it is an unnatural measure rarely adopted by primeval nature in the 


\section{AMERICAN S L L I CULTURE}

propagation of the woods. Primeval forms of coppice forest proper do not exist.

Species propagating their kind, at least partially, by rootsuckers frequently form rootsucker forests closely resembling coppice forests proper

Chestnuts, Locusts and many other hardwoods broken down by storm may form natural sprouts from the stumps. Still, these cases are probably so scattering as not to deserve the name of "forms of primeval sprout forest."

Thus there remain two large groups of sprout forests, namely "Culled Sprout Forests" and "Cultured Sprout Forests." In both cases we have to deal but with the large-area form or compartment form of coppice.

Woods seemingly consisting of uneven-aged coppice shoots, mixed in groups or individually, are treated as "forms of coppiceunder-standards" (Par. LXXIII to Par. LXXVIII), unless the standards are worthless and promise to remain worthless.

\section{A. Culled forms of coppice:}

These forms emerge either directly from onnivendible primeval forms, or else have passed through the intermediate stage of " culled coppice under standards."

\section{Characteristic for culled coppice is:}

An even display of growth.

A surprising density of stand.

The presence of some weathered and worthless snags and stumps protruding from the even sea of coppice.

\section{Subdivision of culled coppice:}

Uniformity being characteristic for culled coppice, sub-forms can scarcely be singled out, unless the means of coppicing-fire or axeserve as a criterion. Hence there might be distinguished

a. The form of fire-cullad coppice, and

b. The form of axe-culled coppice.

This distinction is not made on the basis of different display; but on the basis of difference in treatment required by the two forms.

\section{Treatment of culled coppice:}

The culled coppice is regenerated by being coppiced anew. In the case of fire-culled coppice, it is wise to delay the second cut as little as possible.

Coppicing in patches or small groups is not advisable, the young shoots requiring all the light available for rapid lignification.

An insufficient number of stumps may call for artificial reinforcing. 
Improvement cuttings convert poor coppice shoots interfering with their neighbors from above into healthy coppice shoots pressing their neighbors helpfully from below.

\section{B. Cultured forms of sprout forests:}

No form of cultured forest ean be obtained more easily and more cheaply than the form of cultured coppice.

In the European luardwood forests, the cultured coppice of the past has often served as the forerumer of the cultured seed forest of the present sylvan era.

I. Characteristic for cultured coppice is an even stand, a dense stand, absence of undesirable competitors and of tree weeds.

II. Subdivisions of cultured coppice forms are:

a. The simple form of cultured coppice, where all shoots hare the same age.

b. The two-storied form of cultured coppice, where the growing stock displays two tiers of leaf canopy, viz., an upper and a lower tier, the age of the tiers differing by half the length of a rotation.

In addition, a form of "high stumps" is usually distinguished, where trees are cut some six to ten feet above ground and where the shoots forming on such stumps are cut at short intervals. This form, adapted particularly for the production of fascines, is known as:

c. The pollarding form of cultured coppice.

In this form, rotations of one to five years are usually adopted, and the "lopping" takes place in the "new wood." The types of this form are found, in the case of Willows, near the levees; and in the case of Mulberry, in the silk-producing districts of the world.

\section{Treatment of cultured coppice forms:}

Regeneration in the cultured forms of coppice is, of course, by coppicing, lelped by planting stump-plants, euttings and suckers, or by layering. Regeneration may proceed against the direction of the wind which brings the heavy frosts of spring and fall (blizzarddirection). Cleanings and thinnings are often indicated.

\section{Paragraph LXXI. Critical remarks on sprout forests.}

The sprout forest furnishes small-sized timber, notably firewood and farm supplies, but no or little saw timber. Its production 
is not so many-sided as that of the high forest, and for that reason not so sure to find a ready market.

On the other hand, allowing of shorter rotations, the timber investment is much smaller tlian in the seed forest, and the returns from "final yields" are more frequent.

A comparatively small area may produce, under a coppice form, a regular sustained yield.

The soil of the forest is frequently exposed, and shows a thin layer of humus. Shallow soil is, however, suflicient for the welfare of a sprout forest.

The water-retaining capacity of the sprout forest is small.

The sprout forest is less exposed to storm, fire, snow and insects (being broad-leafed usually), and more exposed to late and early frosts than the seed forest. As a stock pasture, it is more productive than the seed forest; but also nore damaged by pasture.

The expense of regeneration and of pedagogie is slight. 'The species forming shoots from below the ground and those forming root-suckers allow of long rotations usually.

\section{Paragraph LXXII. Sprout forests by species.}

\section{A. Oaks :}

\section{Culled Oak coppice:}

Culled Oak coppice is usually fire-culled. The stumps do not relax and do not refuse to produce new shoots after continuous firing. Still, the shoots become weak, stunted and bushy-crowned, and soon refuse to grow in diameter as well as in height.

It is remarkable to find that these worthless shoots may be replaced by strong sprouts after coppicing with the axc.

The poorer the fire-culled Oak coppice, the greater is the improvement obtainable by axe-coppicing.

\section{Cultured Oak Coppice:}

In Europe, Oak coppice is the form in which Oak bark is raised for tanning purposes, under a rotation of fifteen to twenty-five years.

In America, coppiced Oak is used only for charcoal and firewood,-rarely for railroad ties. Rotations yielding ties will not allow of a ready reproduction under the coppice form, unless the soil is very strong.

At Biltmore, Post Oak three inches through, White Oak ten 


\section{THE ART OF THE SECOND GROITH}

inches through, Black Oak and Scarlet Oak twelve inches through are unlikely to sprout.

A rotation of not to exceed forty years seems indicated. Such a rotation might also yield hoop poles, poles for splitwood fabrics and minor wagonstock.

\section{B. Beech :}

Beech coppice yields firewood, charcoal and so-called retortwood for dry distillation.

The sprouting capacity of the Beech invites short rotations. strong soil is required.

\section{Hickory :}

Hickory coppice promises good financial results on strong soil only. Fires must be strictly kept in check, owing to the heavy scars which they inflict on Hickory. Rotations of about twenty years, low stumps and winter cutting seem required.

On Biltmore soil, stumps over six inches in diameter usually refuse to sprout.

\section{Locust :}

Locust coppice densely planted on old fields seems to be a good investment, although the poles thus prodnced consist of sappy wood undesirable for fence posts. The young shoots suffer from a pithboring moth (Ecdytolopha species).

The sprouting capacity is very good, helped by the ready formation of rootsuckers.

In Germany, wagon stock is obtained in rotations of twenty years,

\section{E. Chestnut:}

Chestmut is the American species best adapted for the coppice forest. Stumps of any diameter emit sprouts. A rotation of twenty to forty years will yield vineyard stakes, hop poles, telephone poles, posts, rails, ties and wood for the extraction of tannic acid; a rotation of five years is said to be used for the production of hoop poles for barrel hoops.

The European complaint does not seem warranted in America to the effect that rotations exceeding twenty years invite a disease known as "heart-rot."

In Alsace-Lorraine, thinnings take place in the tenth year; the cut is made in early winter, and the stumps are sometimes protected from the influence of frost by heaps of brush. In the Appalachians, such precautions are not called for. It is unnecessary, if not urwise, to reduce the number of sprouts starting from 


\section{AMERICAN SYLVICULTURE}

one stump artificially. Spring cutting and high stumps are objectionable.

On dry and impoverished soil, or under the regime of fires, Chestnut coppice is hopelessly lost.

\section{F. Cottonwood:}

The sprout forest of Cottonwood produces match stock and pulpwood. The stmmps have little vitality and will not endure more than four rotations of twenty years each. Very low stumps are required to insure healthy spronts and to encourage the production of rootsuckers. The growth is very fast in the first years.

\section{G. Willows (Osier-culture):}

Osier culture is considered a money maker in Germany where labor is cheap. It is now in vogue in New York and in New Jersey. The best species are Sahx viminalis, Salix amygdalina, Salix purpurea, Salix acutifolia (caspica). The rotation comprises one or two years. With the exception of Salix caspica, a moist soil is required (meadow land in river bottoms) by the willows.

The stumps do not yield a return for more than twelve to sixteen years.

For the formation of an Osier grove, shoots two feet long are nsed, of which about 80,000 are put in per acre. It is stated that the more shoots there are per acre, the better is the quality of the Tillow, as branchy stuff cannot be used for basket making.

Cultivation between the rows is said to be very advisable or eren necessary, especially in the first year. There are many insects feeding on the leaves and many fungi besetting the leaves of the Willows.

A one-year rotation is best. After three or four years, however, a two-years' rotation frequently intervenes, so as to allow the root to develop unhampered. The shoots two years old are used for the framework of heary baskets. The entting takes place in July and August. Krahe, liowever, advises cutting in November.

The first cost of an Osier plantation is very high. After Krahe, the net yield amounts to $\$ 32$ per acre per annum. 


\section{CHAPTER IV}

\section{THE COMPOSITE FOREST}

\section{Paragraph LXXIII. Genesis of the composite forest and its types.}

The composite forest contains specimens having originated from seeds as well as specimens having originated from sprouts.

The primeval forests found in the Chestnut region of the Southern Appalachiaus, notably on windswept sites, exhibit this form frequently.

Where the virgin character of the hardwood forest has been destroyed by fire and maltreatment, sprout-forests and seed-forests are intermixed frequently.

All over the Piedmont Platean there are found luge tracts of Pine and hardwood land wherein the Pines are evidently the offspring of seeds, while the hardwoods show the earmarks of sprout growth.

H. S. Graves, in his "Principles of handling woodlands" distinguishes between two "systems" of composite forest:

a. Coppice with standards, when the bulk of the forest area is occupied by sprouts cut in short rotations;

b. Pole-wood coppice, when an even-aged stand of spronts and trees from seeds is allowed to grow to pole-wood size $(40-70$ years of age), and then reproduced in part by sprouts, in part by natural seeding.

The form of coppice under (with) standards is the most important sylvicultural form of the composite forest. It is used extensively in the old country. It was introduced, in suitable localities, most successfully on the Biltmore Estate. Its advantages are such as to commend it particularly to the owner of hardwood forests in Eastern North America. And it is well worth while to consider it in detail.

"Coppice under standards" consists of an underwood and of an overwood.

The underwood is nothing but simple, even-aged coppice.

The overwood exhibits the selection, sometimes the group form of seed forest, and is supposed to recruit itself from seedlings. 


\section{A. The underwood:}

I. Species: The species forming the underwood must combine natural sprouting eapacity with shade endurance. On good soil, a smaller amount of both qualities is required. Excellent species for underwood are Basswood; Chestnut; Gum; Hornbeam; Calmia and Rhododendron; on strong soil, Ash and Hickory; underneath a light overwood also Oak.

II. Purpose: The underwood supplies or may supply

a. Companions for the younger age-classes of the overwood, causing them to form elear boles;

b. Protection of the soil, enriching it by its humus;

c. Firewood and small timber; also tanning material.

The underwood yields a direct revenue only in case "c." Obviously, where there is no market for firewood or small timber, the underwood is only indirectly useful.

III. Formation: For diameter, vitality and number of stumps also for manner and season of cutting, the remarks of Par. LXVIII. A. (about coppicing) hold good.

\section{B. The overwood:}

I. Species: The species forming the overwood should be stormfirm and small crowned. Light demanders are usually preferred.

Yellow Pines produce wide-ringed timber on strong soil and suffer from sleet. Good species are: White Oaks, Red Oak, Hickory, Walnut, Yellow Poplar, Black Cherry, Locust, Larch, ete.; on poorer soil Yellow Pines and Long-leaf Pine (over Black Jack).

II. Age-classes: The number of age-classes in a normal overwood equals the fraction $\frac{\mathrm{R}}{\mathrm{r}}$ wherein

$R$ represents the length of the rotation in the overwood, and $r$ represents the length of the rotation in the underwood.

The normal difference of age between consecutive classes is " $r$ " years.

III. Normal formation: The overwood is composed of "standards" regenerated, at the year of coppiced underwood, from selfsown seed falling from the overwood or, in the cultured forest, from planted seedlings. The seedlings of the overwood grow up immerged and often badly endangered in the new underwood. When this is coppiced at the age of " $r$ " years, an improvement cutting takes place simultaneously removing misshapen or damaged standards of the various older classes as well as the weaklings in the youngest class. By this improvement cutting the leaf canopy of 
the standards, which has had ample chance of enlargement during the past " $r$ " years, is eut back to a normal limit.

The older an age-class is, the smaller is the number of its constituents.

C. Abnormal formation of overwood and underwood:

A normally proportioned and normally formed overwood is never found. Deficiencies lie

1. In a lack of one or the other age-class;

2. In an abnormal number of constituents per elass;

3. In the fact, that the overwood is partially recruited from stoolshoots and not from seedlings.

Abnormal coppice over-standards is the usual consequence of the culling of primeval hardwoods or of primeval pineries forming a superstructure over Oaks, Hickories, Gums, etc.

The burned slopes and outskirts of the Alleghanies usually belong to the coppice-under-standard form. The fire-coppiced underwood here consists of Soft Maple, Calmia, Rhododendron, Chestnut, Oaks, Hickories, Black Gum, Sourwood, Halesia, etc., etc., all of which are usually devoid of value.

Culled and fired forest of Pinus echinata, taeda and palustris frequently belong to the same form, with Oaks in the underwood and the Pines in the overwood.

\section{Paragraph LXXIV. Pedagogie of the coppice under standards.}

Coppice under standards is or may be tended by cleaning, weeding, improvement cutting, pruning and thinning.

Thinnings are applied to the underwood only; whilst the overwood alone is the object of pruning.

A. Cleaning purports to eliminate undesirable shoots in young coppice, or removes desirable sloots liable to interfere with the development of overwood seedlings imbedded in the coppice.

B. Weeding removes weed trees, usually tending to form new sprouts from the stumps of the weed trees removed. Weeding is a necessity where a culled forest is to be converted into a cultured forest, the culled forest containing a large number of weed trees.

At Biltmore, the weed trees removed are Black Gum overshadowing the coppice and the Pine seedlings standing therein; 


\section{A IERICAN SILVICLLTURE}

fire-scalded Oaks or Hickories, bent and low crowned; wolfs of Yellow Pine; pretentious Dogwoods or Halesias and so on.

C. Improvement cuttings improve the prospects of the overwood, remove undesirable members of the overwood and regulate the number of the constituents forming an age-class of the overwood. "The normal cuttings in the overwood are improvement euttings."

In semi-normal woods, the oldest class of the overwood is entirely removed. Class II is reduced to the former membership of Class I; Class III is reduced to the former membership of Class II, etc. It stands to reason, that the least desirable members of a class should be thus removed. In semi-normal woods, the improvement cuttings take place at the time at which the underwood is ripe for coppicing.

The improvement cutting yields timber of all sorts and of all sizes obtained from the various age-classes.

The improvement cutting does not regularly intend to help regeneration. Frequently, of course, the stumps of trees removed by the improvement cutting form sprouts partaking in the coppicetier.

D. Pruning: Dead branches of the overwood trees might be removed to develop timber clear of dead knots.

Live branches of overwood trees formed low on the bole are removed to lessen the intensity of the shade to which the underwood and the seedlings imbedded therein are locally subjected.

The members of the overwood, owing to their free position, are apt to form and retain heary branches. The act of pruning in coppice under standards corresponds with that described in paragraph LXIII for high forest.

The coppice is pruned only in rare instances, f. i., for the improvement of oak tanbark.

E. Thinnings are sometimes indicated in dense coppice in order to increase the food and light supply of the youngest age-class of overwood imbedded in the coppice; or in order to increase gradually the air space surrounding the members of that elass, so as not to subject them to the shock of sudden exposure at the time of coppicing; or to obtain the ends of Par. LXII. A., especially where the overwood classes appear in groups; or to improve the quality and the quantity of the bark in tanbark coppice.

In all cases, the thinning must yield a surplus revenue. 


\section{Paragraph LXXV. Key to the forms of coppice under standards.}

The primeval woods elo not contain any form of coppice under standards. In culled hardwood forests, on the other hand, these forms are almost regularly met with.

\section{A. Culled forms of coppice under standards.}

I. Characteristics: Primeval hardwood forests are usually paucivendible only. After lumbering the merchantable species and sizes, a rank growth of coppice shoots frequently enters an appearance under the assistance of fires, overshadowed by poles and trees of all age-classes devoid of present value. Many individuals of the overwood are badly burned; or are hollow, fungus decayed, worm riddled, etc.

Thus whilst the underwood consists of fire coppice or shoots sprouting from the stumps of merchantable trees, the overwood consists of undesirable species and of immature trees usually crippled by firing and felling. In addition, there are plenty of weed trees left on the ground. The younger age-classes of the overwood are usually absent.

In forests originally composed of a Pine overwood and of a hardwood underwood-a form once frequently found all over the Southeast-the lumberman usually removes merely the taller Pines scaling over ten inches in diameter. The smaller Pines, if fireproof, henceforth join with the hardwood trees and hardwood poles in the formation of an overwood. The underwood consisting of miserable fire sprouts is continuously clipped by forest fires. The butts of these "snags" are flattened on the ground, as if liquid wood had hardened on it. The shoots, weakly inserted on the callus, can be torn off easily.

If these snags are eut, fresh shoots will form, of much greater vigor and of greater strength at the point of insertion.

II. Subdivisions of culled coppice under standards:

The number of forms of coppice under standards is particularly great, owing to the variations occurring in the tiers of forest, viz.: the overwood and the underwood.

a. The overwood is omni, multi, or pauci vendible, as the case may be. It is arranged either in groups or in patches (individuals) imbedded in the coppice. Thus we obtain:

1. The form of culled coppice under standards raised in the group type, and 
2. The form of culled coppice under standards raised in the selection type.

b. The leaf canopy of the standards covers a certain percentage of the ground. This percentage, where high, forces the underwoods into a minor role; where small, it allots to the underwood the major part.

The Long-leaf Pine woods of the South, after heavy culling, illustrate the latter form; the Shortleaf Pine woods of the Biltmore l'lateau exhibit the former form. These forms might be designated as:

1. The form of prevailing coppice under standards;

2. The form of coppice under prevailing standards.

c. According to the means of coppicing, there should be distinguished

1. The form of fire-culled coppice under standards;

2. The form of axe-culled coppice under standards.

III. Treatment of culled forms of coppice under standards.

Improvement cuttings and, where improvement cuttings camnot the made, weeding are usually required.

Fire coppice should be cut down, wherever the growth is stagnant.

An undue preponderance of standards may be checked by the use of the axe.

Planting of seedlings can usually be dispensed with. Where it is advisable to plant seedlings, the coppice must be cut clean to legin with.

\section{B. Cultured forms of coppice under standards:}

I. Characteristic for the cultured forms of coppice under standards is the lack of weed trees and of unbealthy standards; further the geometric regularity of the figures considered as compartments and sub-compartments.

The overwood is composed of storm-firm and light-demanding species.

II. Subdivisions of cultured forms of coppice under standards.

As in the culled forest there should be distinguished:

a. The form of cultured coppice under standards raised in the group type with

1. Prevailing coppice, or with

2. Prevailing standards.

b. The form of cultured coppice under standards raised in the selection type with 
1. Prevailing coppice, or with

2. Prevailing standards.

The standards might be planted in regular rows (Charles Heyer's idea) or in regular groups or-irregularly-in suitable places; or they might be recruited from self-sown seed under the selection type.

III. Treatment of cultured forms of coppice under standards.

The regeneration of the overwood as well as its pedagogie is difficult, unless the group type is carried through. Individual seedlings are very apt to be suffocated in the mass of faster-growing coppice and require continuous, careful attention. Thinnings are required to prepare the youngest class of standards inmerged in the coppice for its future task.

The overwood is sometimes pruned-in this case of dead as well. as of live branches.

\section{Paragraph LXXVI. Critical remarks on the coppice under standards.}

The coppice-under-standards forest combines the good qualities of the high forest with those of the coppice forest. It furnishes timber of all sizes in the largest possible variety. It requires a moderate investment sunk into the growing stock and allows the overwood to grow into $\log$ size at a very fast rate. It is a good form for the owners of small woodlands desiring steady returns. It protects the fertility of the soil better than the coppice form.

The logs furnished by the overwood raised selectionwise are necessarily branchy and wide ringed, with the incident bad and good qualities of such logs. The trees usually do not yield more than two saw logs.

Where the underwood is unsalable or low priced, stress must be laid on a prevalence of the overwood. Where it is valuable as a tanning material or as wagon stock, the underwood is favored.

The danger from fire, since hardwoods are usually at stake, is not very great. The density of the brushy underwood, however, aggravates the difficulties confronting the fire fighter.

In Europe, the forms of "coppice under standards" are more and more abandoned and restricted to the inundation districts along the rivers. Here, on strong soil, the undergrowth endures an enormous amount of shade, and the overwood develops fairly long boles. in spite of a free position. 
The coppice-under-standards form in Europe requires careful, minuie and honest management: careful, because the leaf canopy of the overwood rapidly increases during the rotation of the underwood; minute, because individual trees or groups of trees must be continuously watched; honest, because an unscrupulous forester or a thoughtless owner may easily and heavily reduce the capital of the forest whilst claiming to merely withdraw revenue proanced by it.

In America, in the hardwood forests of the Alleghanies and in the pineries of the South, the form is destined to play a most important role. The form exists and will have to be retained for decades of years to come, owing to its tempting financial merits; the ease and cheapness of regeneration; the short period of waiting between remunerative cuts; the variety of produce; the fast rate of growth; the small amount of growing stock required for "sustained" yields and so on.

In the course of time, curtailing the cut of standards or allowing the coppice to grow into larger sizes, the forester may gradually convert the coppice-under-standards forest into a seed forest. The arerage growing stock, per acre, in the seed forest contains about twice as many cords of wood as the average growing stock in the coppice-under-standards forest.

On the other hand, by removing all standards, the form of simple sprout forest is readily obtained.

In the Oak-coppice-under-Pine-standard forest of Biltmore it has been observed that the Pine poles suffer less from bark beetles than they do in the denser polewoods of the seed forest of Pine.

\section{Paragraph LXXVII. Coppice under standards by species.}

By culling and firing, every primeval forest of hardwoods existing in the United States is converted into coppice under standards. Again, many, nay, almost all two-storied high forests in the Sonth having Pine in the overwood and hardwood in the underwood present the form of coppice under standards in a modified manner.

The number of constellations of species fit for a place in the overwood and in the underwood is endless.

A few remarks on characteristic forms must suffice.

A. Chestnut-coppice under standards of Yellow Poplar, White, Chestnut and Red Oak, Hickory, Ash, Locust,-the Pisgah Forest form. 
Certain age-classos of the standards (the sapling stage and the pole stage) are invariably absent, owing to the fires of the last decades. The number of Chestnut stumps is deficient. The weed species of the forest (Halesia, Soft Maple, Dogwood, Calmia, etc.) readily replenish the coppice-stratum. The standards regenerate their kind readily where the weeds are not too rank. No means are known by which to extirpate the tree and bush weeds preventing $n$. s. r. of the standards in a sufficiently promising way. Heary pasturage in early spring practiced before the Chestnut stumps had time to sprout and before the seeds of the standards (excepting Chestnut, Oak and White Oak) had time for germination may solve the problem. Such pasturage, whilst it checks the weeds, presses the seeds of the standards at the same time into the mineral soil. Other remedies are: Deadening; cutting with ligh stumps left; bark peeling; removing side branches with a brush axe, ete. However, entire extirpation of the ligneous weeds does not seem financially advisable at the present time. Frequently it might be best to leave the weeds untouched for the time being, postponing the battle until the undergrowth of seedlings and coppice shoots requires increased influx of light. Then, too, the cutting of the weeds will force them to be satisfied with a subsistence below the level of the underwood.

Chestnut standards slould not be left, since the shock of a sudden change of surroundings causes them to sicken. The adjoining woods will tend to reinforce the regeneration area by $n$. $s . r$. of Chestmut, where the compartments simultaneously coppiced are small or narrow. Artificial reinforeing seems unnecessary although the planting of Walnuts in suitable places may prove remunerative.

\section{B. Oak coppice mixed with Hickory coppice under Pine standards.}

This form prevails on the Biltmore Plateau and over vast areas in Arkansas, Mississippi, Alabama, North Carolina, South Carolina, ete.

Sylvicultural treatment is impossible unless the Oak can be removed to a nearby fuel-market.

Rotations for the coppice of thirty to forty years seem best.

Shorter rotations are required where the coppice is badly damaged by fires.

In seed years of Yellow Pine, the coppiced area should be as large as compatible with the market. It might be wise to eut early in fall and to burn the coppice before the Pine seeds begin to fall. Seed years of Pine at Biltmore occur at intervals of seven 
years. Improvement cuttings should make up the sustained yield, as far as possible, in years of deficient seeding; or such compartments slould be taken in laand, in which the coppice growth is richly beset with Pine poles and Pine saplings.

In the course of the improvement cuttings, the nuclei of n. s. r. of Pine require careful attention. Weeds like Chinquapin and Black Gum are checked wherever they obstruct the underwood; where they form part of the underwood, especially under groups of Pine, they should be thankfully accepted as shade-bearing improvers of the soil.

White Pine is not adapted to the formation of standards. During the earlier stages, it retains its branches badly where isolated in Oak Coppice. During the later pole stage, it is apt to suffer from windfall. Groups of White Pine standards will answer better than standards indivdually scattered. 


\section{CHAP'TER V}

\section{PROPAGATION OF FOREST PRODUCTS OTHER THAN WOOD AND TIMBER}

\section{Paragraph LXXVIII. Raising of forest by-pro- ducts.}

In many cases better revenue is obtained from the by-products raised in the forest, than from the production of wood and timber. In backwood sections, closed to traffic, forest pasture often yields the only means of obtaining revenue. In densely wooded districts, the combination of agriculture with tree growth is often advisable. The main products thus obtained and the industries connected with their production are:

\section{A. Tanbark and raising of tanbark:}

The thickness of the bark used for tanning purposes and obtained either under a high forest or under a coppice forest system is increased by proper thinnings. In Oak bark coppice abroad the number of stumps per acre is about 2,000, reinforced by stump planting at each cutting. The healthier the growth of the shoots, the better are the tanning contents of the product.

In America, at the present time, no difference is made in the price of old, corky bark and of young, fleshy bark obtained from shoots but five inches in diameter.

\section{B. Cork industry:}

The cork industry. conducted in Southern France, Spain, Portugal and Northern Africa. For America, its introduction seems highly advisable.

Expcriments made in Georgia and in the Carolinas with plantations of Cork Oak diave produced very healthy trees; for reasons unknown, however, the cork production was deficient. Possibly the wrong species or the wrong variety was selected, or else mistakes were made in choosing soil, exposure and sylvicultural treatment.

Mayr recommends experiments with Quercus variabilis for the section of Germany productive of Castanea vesca.

\section{Forest pasture:}

Up to 1880, forest pasture in the Pine woods of the South (Cane-brakes) and in the hardwood forests of the Alleghanies, and 
also of the Lake States, has occupied the rank of the most important forest industry. Nowadays, pasture is indicated on many a windswept ridge where the growth of timber is stunted, whilst the atmospheric moisture allows of a luxurious production of grass. Under nut-bearing trees, hog pasture is highly remunerative. In "strong" coves, the growth of weeds offers splendid forage for cattle.

The more inaccessible the forest, the less is the value of the tree growtl. Here an industry is advisable which converts regetable matter into animal matter.

The advantage gained by pasturage during and previous to regeneration frequently reduces the expense of regeneration.

Whether the fencing of forest pastures is advisable depends on circumstances. A two-stringed barbed wire fence costs $\$ 40$ per mile.

Goats, as extirpators of woody weeds (Corylus, Azalea) are frequently useful on mountain pastures.

Woody weeds damaging the pastures are kept in check by continuous mowing, especially if mowed in August. A limited use of fire, too, improves the pasture. Forest pastmes are invaluable as fire lanes.

Pasturage of cattle extends in Pisgah Forest from May 1st to October 15th. Sheep and hogs require feeding only in February. The revenue made per month amounts per head of cattle, to fifty cents; of horses, seventy-five cents; of sleep, ten cents.

Where the growth of trees on a permanent pasture is too dense, deadening or coppicing is required. Where it is too little or where erosion sets in, the pasture must be abandoned for a number of years. Dead trees placed horizontally on pastured slopes safeguard the pasture by terracing it.

In European and in Indian forests, pasture still plays a most important role, frequently as a prescriptive right encumbering forests owned by the Crown or by the aristocracy.

Relative to forest pasture in the National Forests, see Schenck's "Forest Policy," pages 155 and 157.

lielative to the protection of the forests against undue damages resulting from forest pasture, compare Schenck's "Forest Protection," page 12, f.f.

The American public, for one reason or another, has been slow to realize that the use of forests (by the tax-paying owners) for pasturage is as correct, as justifiable, as legitimate, as is the use of a farm for pasturage. Forest pastures, of course, should not be maltreated any more than farm pastures. 
Unjust and unwise it is if the commonweal, in non-stocklawcountries, permits of the unrestricted use of the woodlands for pasturage by those who neither own them nor pay the taxes thereon; and who do not have any interest in their perpetuation.

Forest pasture in the Prne woods of the South and of the Southwest, in the forests of the Rocky Mountains and of the Cascades, is of utmost economic importance.

Forest pasturage requires regulation in the following points: Number of animals per acre; species of stock and of trees; season of pasturage; remuneration; closed years; firing; responsibility ; supervision; salting; improvements; access.

\section{Forest fruit raising:}

\section{Pecan.}

Large investments are being made in Pecan plantations in the south. Lsually seedlings three years old are planted fifty to sixty feet apart. Payable crops are expected fifteen years after planting. Cultivation and fertilization of Pecan orchards are required just as in apple orchards.

II. Apple-trees planted on freshly cutover woodlands (Northwest slopes) are said to be particularly promising.

III. Chestnuts. Chestnuts are either obtained from the woods where Chestnut trees are grown for timber, or from orchards. In Pisgah Forest seed years are said to occr every seven years. The nuts sell at fifty cents to one dollar per bushel. The mountaineers burn the woods to more readily uncover the nuts.

Oreharding combined with grafting of French Chestnuts (Castanea resca) on the American species has been tried in Pennsylvania with little success owing to forest fires.

In Southern France a large revenue is obtained from the nuts ( $\$ 5$ to $\$ 6$ annually from a good tree).

IV. Acorns. The acorns of the White Oaks are ground as a substitute for coffee (Postum Cereal 80\%). In addition acorns are of high value for pannage and in game preserves.

$r$. Berries. The crop of berries growing in the forest is locally leased to the highest bidder. The huckleberry crop is improved by periodical burning.

VI. Nuts from Western Nut-Pines.

\section{E. Maple sugar:}

The production of sugar depends on the size and on the development of the individual trees, influenced by careful thinning. An underwood and a heary layer of humus is helpful. Planted sugar orchards are rare and suffer from sun scald and from hardening soil. 


\section{A IIERICAN SYLVICULTURE}

\section{F. Naval stores:}

No means are known tending to increase the production of naval stores. The best yield is obtained from healthy, large trees.

\section{G. Rubber and guttapercha:}

\section{H. Truffles and champignons:}

\section{Gingseng (Aralia quinquefolia):}

Gingseng grows in the Alleghanies in well-sheltered north and northwest cores of greatest fertility. The young roots are easily transplanted into nursery beds. The cultivation of gingseng in the woods, however, is not practicable.

\section{J. Sumach leaves:}

The leaves, used for tanning on a large scale, are gathered on abandoned fields in Virgina. No care seems to be devoted to the reproduction.

\section{K. Pharmaceutical weeds:}

A large number of forest weeds have a pharmaceutical ralue and might be locally propagated and fostered.

\section{Peat bogs:}

Peat bogs reproduce themselves where but the top layers are taken off periodically. Small benches are left between the pits utilized.

\section{Fish and Game:}

In the Prussian State forests, twelve per cent of the annual revenue is obtained from hunting and fishing. Private owners in the Adirondacks and in the South draw large revenues from leasing the exclusive privilege of hunting and fishing. For particulars regarding the raising and nursing of Fish and Game see lectures on "Fish and Game Keeping."

\section{Paragraph LXXIX. Combination of sylvicul- ture and agriculture.}

As the woodlot belongs to the farm, so does the farm embraced by woodland belong to the forest.

Strange as it sounds: The forester is charged sometimes with the administration of more farmland than of woodland.

A fair practical knowledge of agrieulture is indispensable with the administrator of forests. Truly agrieultural land within the forest should be cleared in due course, in pursuance of the maxim that every acre of ground must be placed under the (permanently) most remunerative industry. 
The forest farm produces victuals for the lumber camp and forage for the teams and yokes; it yields the best possible fire lanes.

T'nder these circumstances it is not to be wondered at that a locaI, permanent or temporary combination of sylviculture and agriculture is frequently indicated, in sprout forests as well as in seed forests, in cultured forests as well as in culled forests.

\section{A. Reasons prompting the forester to adopt a combina-} tion of sylviculture and agriculture may lie in the following considerations:

I. Frequently it does not pay to eradicate the "weeds" in the forest previous to artificial or natural regeneration by n. s. r. In such cases, the forester may take advantage of the fertility stored up in the humus, using it for a number of years for the production of field crops and freeing the soil incidentally from competing weeds.

II. Similarly the forester is often at a loss to save his regenerations from the attacks of wild or tame animals. Allowing the plantations to pass their earliest youth in the midst of farm crops which pay for the expense of protection from animals by immediate returns, protection for the plantations is obtainable at a reduced charge.

III. The fertility stored away in the accumulated humus, although exhaustible within three or four years, frequently furnishes a snug revenue (especially where farmland is searce, as in all mountain districts) defraying the outlay, or part of the outlay, required for successful reforestation. In a heavy leaf-mould, many species refuse to regenerate their kind.

IV. In the prairies, agriculture must precede the tree plantation, which will not thrive in soil devoid of porosity. The plantation of trees, on the other hand, will protect the farm from drought in summer and from high winds during winter; it will shelter the stock during serere blizzards, ete.

Henry von Cotta, as early as 1819, advocated plantations of trees in rows twelve feet to fifty feet apart, the intervening spaces to be used for agriculture. The trees and the rows were to be decimated gradually, and were again to be reinforced in keeping with the requirements of the farm.

Cotta's plan might be successful where drought is to be dreaded during summer, scorching the grass meadow and the grain field.

\section{B. Modern application:}

I. Field crops intervening between two generations of the forest. All over the pineries of the South where abandoned fields produce splendid polewoods of Pine, the woods are eut at the thirtieth 
to sixtieth year of the trees; the soil is then used for the production of corn, cotton or small grain for a number of years and thereafter allowed to revert to Pine obtained by n. s. r. from adjoining woods. The same system is followed by thousands of farmers in the old country.

II. Field crops temporarily raised amongst and together with forest crops.

a. In sprout forests:

In Germany, the owners of coppice woods, after coppicing, frequently burn the debris on the ground, ploughing the soil roughly thereafter and using it for small grain or potatoes as long as the fresh stool shoots do not overshadow the farm crops too severely.

This system allows the farmer to continuously (although intermittently) produce field crops on steep slopes liable to erosion, witl the help of the fertility furnished by the humus and by the activity of the tree roots.

b. In seed forests:

1. In the early stages of sylviculture, acorns and pine seeds were frequently planted with barley, oats or summer rye. Compare Par. XV.

2. Sir D. Brandis has established in Burmah a system named "toungya" by which seedlings of Teak, planted with rice by native lessees on government reserves, obtain protection from wild animals and fires as well as from the Bamboo threatening to suffocate the seedlings.

3. A similar system has leen practiced since 1810 in the German Rhine valley where splendid polewoods of White Oak have thus been raised. Here in years past the returns from toungya used to more than cover the expense of forest planting and protecting. The field crops shade the Oak slightly and tend to protect it from the effect of late frosts as well as from the attacks of grub worms (Melolonthidae). At Darmstadt, Germany, the pineries are often regenerated by this method.

4. In Western N. C., the expense of elearing the forest for field erops amounts to ten dollars or twenty dollars, according to the density of the growing stock and according to the yield derivable from the sale of timber removed.

On good forest soil a few years of corn crops are apt to refund the outlay incurred for clearing.

Thereafter the Pines, the Oaks, the Yellow Poplars and the Ashes of the adjoining woods will quickly produce a superior plantation of trees.

Where the soil is stocked with tree weeds, and where immature trees must not be sacrificed, the system can be strongly endorsed. 


\section{ALPHABETIC INDEX}

A PAGE

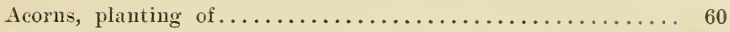

Advance growth types of natural seed regeneration........ 134

Agriculture combined with sylviculture.............. 196

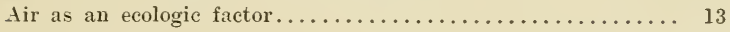

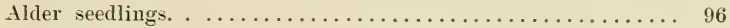

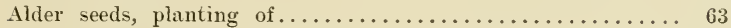

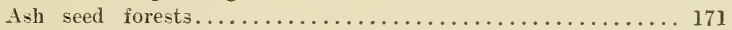

Ash seedlings. . . . . . . . . . . . . . . 100

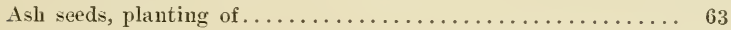

Atlantic forests. . ....................... 24

B

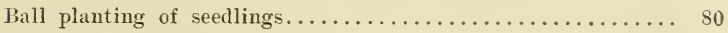

Balsam Mlountains. . ......................... 4

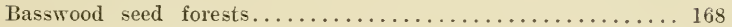

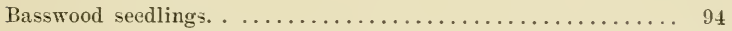

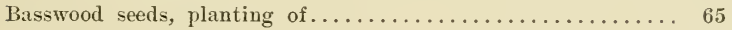

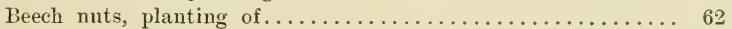

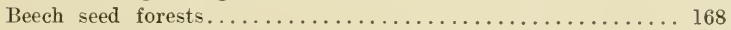

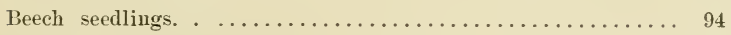

Beech sprout forests.......................... 181

Biltmore Forest. . ....................... 4

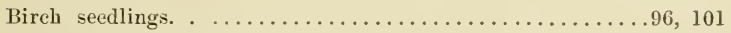

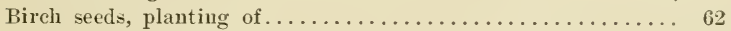

Black Cherry seeds, planting of ................ 66

Black Gum seeds, planting of ................ 67

Black Locust seedlings....................... 94

Black Locust seeds, planting of.................. 65

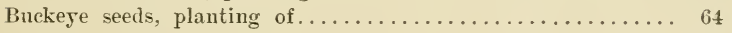

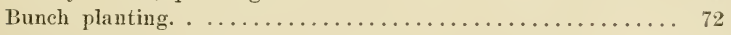

By-products, raising of .................... 193

C

Catalpa seedlings. . . . . . . . . . . . . . . . . 100

Characteristics of forms of seed forests............ 157 
Cherry seedlings. . . . . . . . . . . . . . . . . 97,100

Chestnut coppice under stindards................. 190

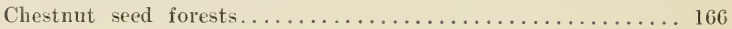

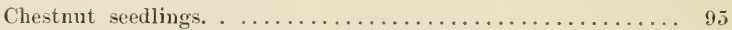

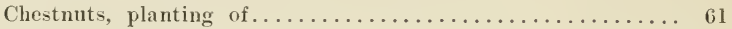

Chestnut sprout forests.................... 18

Classification of messmates:

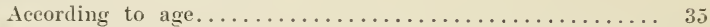

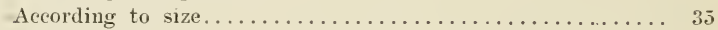

Cleaning :

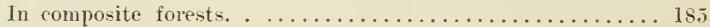

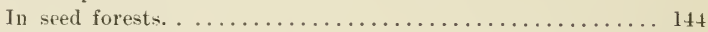

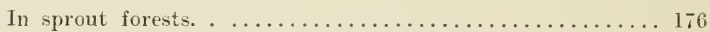

Cleared types of natural seed regeneration.............. 114

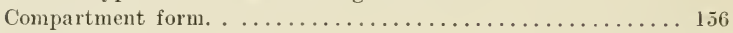

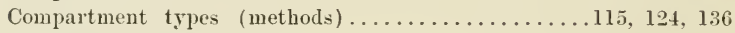

Composite forests, defined .................... 30

Composite forests :

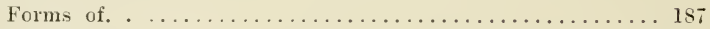

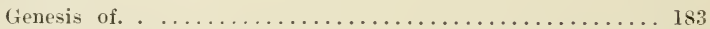

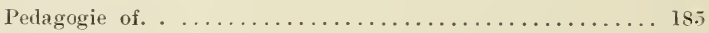

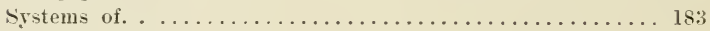

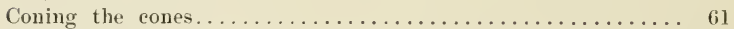

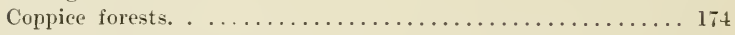

Coppree under standards..................... 18

Cork industry. . . . . . . . . . . . . . . . . . . 193

Culled seed forests:

Forms. . . . . . . . . . . .

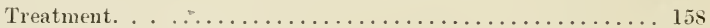

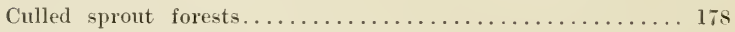

Cultured seed forests:

Forms. . . . . . . . . . .

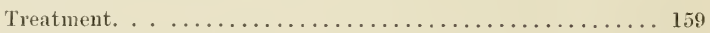

Cultured sprout forests...................... 179

Cuttings (osier). . ......................... 176

D

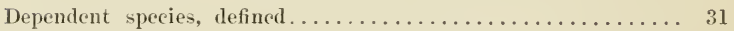

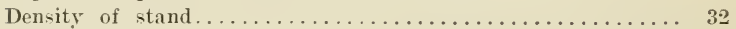

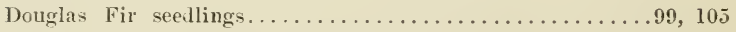

Douglas Fir seeds, planting of .............. 70 


\section{A L PHABETC INDEX}

$\mathrm{E}$

PAGE

Ecologic factors of growth................... 12

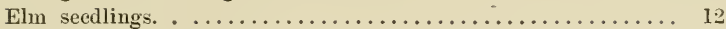

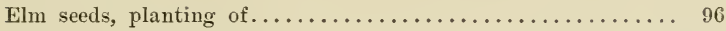

Enesar, interpretation of $\ldots \ldots \ldots \ldots \ldots \ldots \ldots \ldots \ldots \ldots \ldots \ldots \ldots \ldots \ldots \ldots$

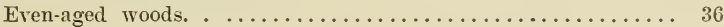

\section{F}

Final eutting in natural seed regeneration............. 128

Fir (abies) seedlings......................... 105

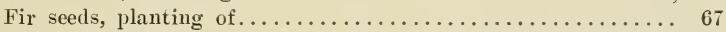

Forest gardens. . ........................ 86

Forest regions:

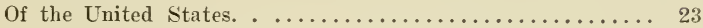

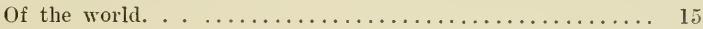

Forms :

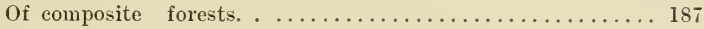

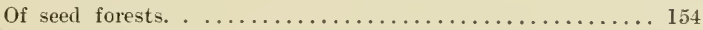

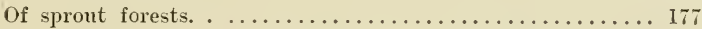

Fruit raising in the forests..................... 195

Genesis :

Of composite forests. . .................. 183

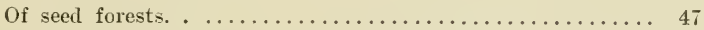

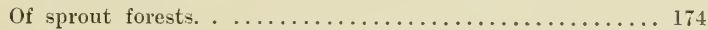

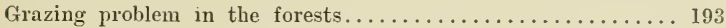

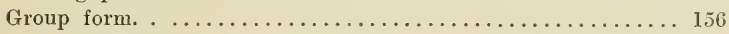

Groups, defined. . ................................ 30

Group types (methods) of natural seed regeneration..119, 132, 138

Growing space of a tree....................... 33

H

Heat as a sylvic factor. $\ldots \ldots \ldots \ldots \ldots \ldots \ldots \ldots \ldots \ldots, 14$

Hemlock seedlings. . ........................ 107

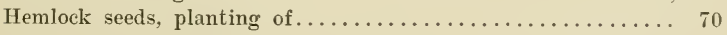

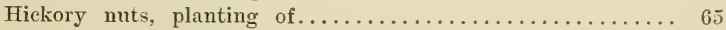

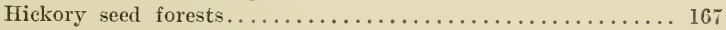

Hickory seedlings. . ....................... 101

Hickory sprout forests...................... 181 
I

Improvement cutting:

PAGE

In eomposite forests. . . . . . . . . . . . . . . . 185

In seed forests. . .......................144, 146

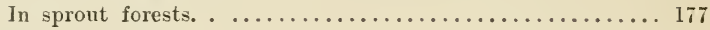

Intermediate species. . ........................ 39

$J$

Jack Pine seedlings........................ 98,103

$\mathrm{L}$

Lareh seedlings. . .......................... 99

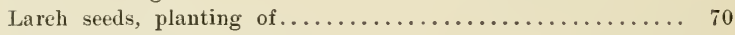

Lawson's Cypress seedlings....................... 106

Lawson's Cypress seeds, planting of................ 71

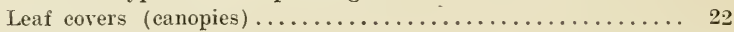

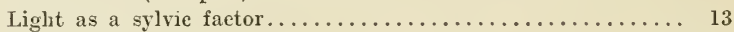

Light demanders. . ........................... 37

Locust sprout forests......................... 181

II

Maple seed forests............................. 170

Maple seedlings. . . . . . . . . . . . . . . .

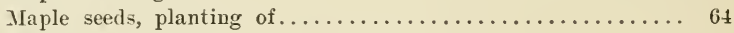

Methods of natural seed regeneration................

Mexican forests. . ........................... 26

Mixed forests, defined......................... 31

Mixed woods and pure woods....................... 40

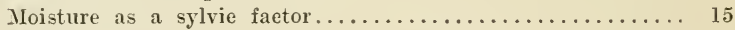

Mound planting. . . . . . . .

$\mathrm{N}$

Natural seed regeneration..................... 107

Compartment types. . . . . . . . . . . . . . . 115, 124, 136

Group types. . ............................. 132, 138

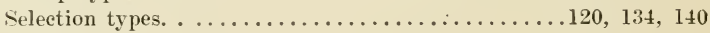

Strip types. . . . . . . . . . . .

Natural seed regeneration, key to the types of ............111 f.f.

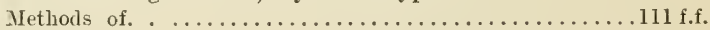

Types of. . . . . . .

Natural seed regeneration, types:

Where lumbering coineides with rejuvenescence......... 122

Where lumbering follows after rejuveneseence......... 134

Where lumbering precedes rejuveneseence. . ............ 114 
PAGE

X. S. R., interpretation of abbreviation

Nurseries. . . . . . . . .

Commercial. . . ....................... 84

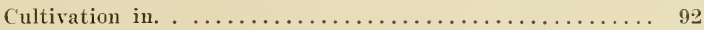

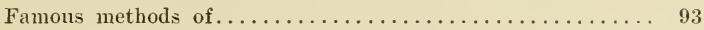

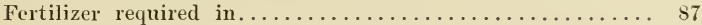

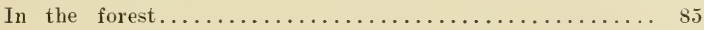

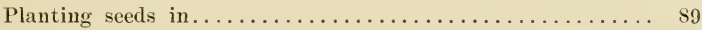

Weeding in. . . . . . . . . .

$\mathrm{O}$

Oak coppice under standards................... 191

Oak seed forests......................... 165

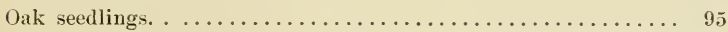

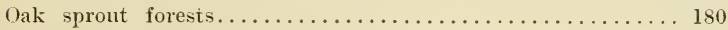

Osier culture. . . . . . . . . . . . . . . . . . . . 182

Overwood in composite forests.................. 184

$\mathrm{P}$

Pacific forests. . . . . . . . . . . . . . . . . 28

Pasture in the forests....................... 193

Pedagogie:

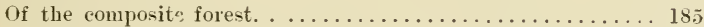

Of the seed forest. . . . . . . . . . . . . . . . . . . 144

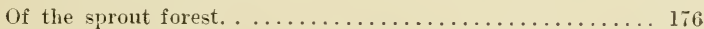

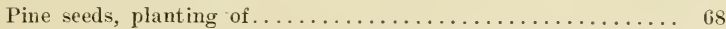

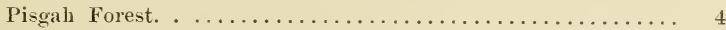

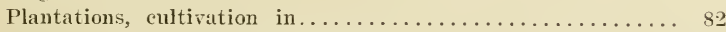

Planting boards for transplanting............... 91

Planting, geometrical arrangement............... 7 ?

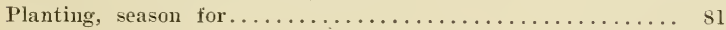

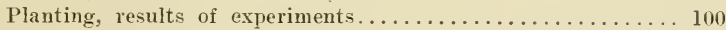

Planting tools. . ......................

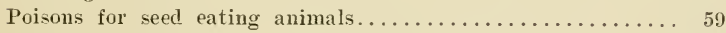

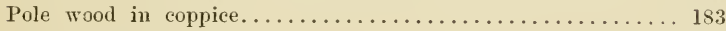

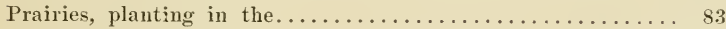

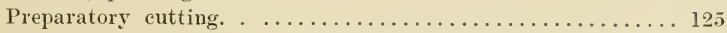

Preparatory stage of natural seed regeneration.......... 125 Primeval forests:

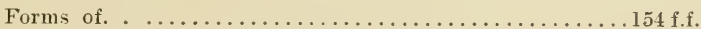

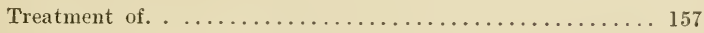

Principles of sylviculture, Mayr's.............. 42 
PAGE

Protection of seedlings..................... 92

Pruning:

In composite forests. . . . . . . . . . . . . . . . . 155

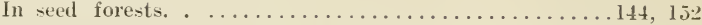

In sprout forests. . . . . . . . . . . . .

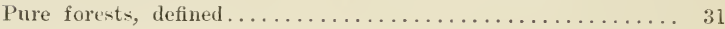

$\mathrm{R}$

Red Cedar seedlings......................99, 106

Red Cedar seeds, planting of ................. 1

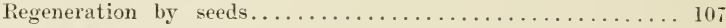

Root bacteria. . . . . . . . . . . . .

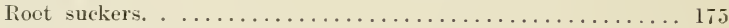

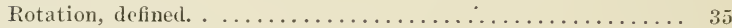

Ruling species, defined $\ldots \ldots \ldots \ldots \ldots \ldots \ldots \ldots \ldots \ldots \ldots \ldots$

S

Sassafras seeds. . ........................ 66

Seed eating animals.......................

Seed forests:

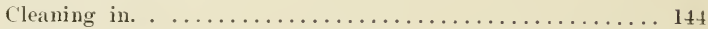

Defined. . . . . . . . . . . . . . 30

Described by species..................... 165

Seed forests, forms of:

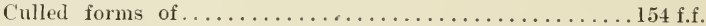

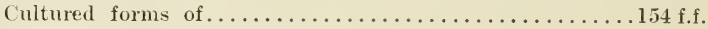

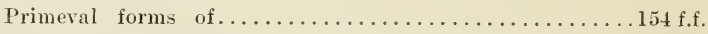

Seed forests, improvement enttings in ............

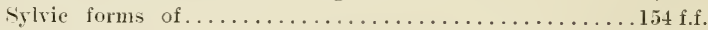

Thinnings in. . . . . . .

Underplanting in. . . . . . . .

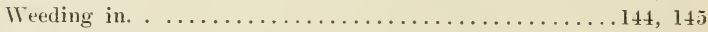

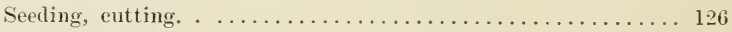

Direct seeding. . ....................50, 54

Stage of natural seed regeneration..............

Seedlings, age and size to be nsed............... 74

By speeies. . .......................

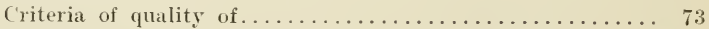

Of hardwoods and softwoods....................

Number per acre used................... 74

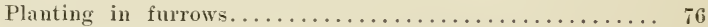

Planting in holes. . . . . . . . .

Planting of. . . . . . . . . . 


\section{ALPHABETIC I I DEX}

Seedlings-Continued.

PAGE

Of softwoods.

Protection of.

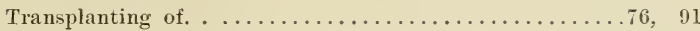

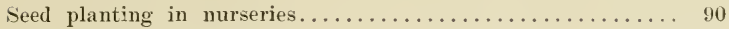

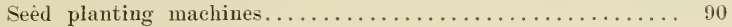

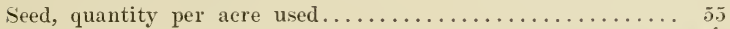

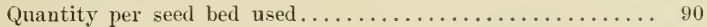

Regeneration. . ...................... 107

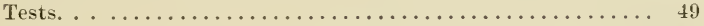

Years. . .......................... 49

Seeds, extraction of seeds from cones............... 51

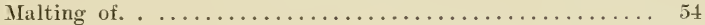

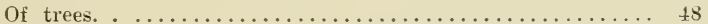

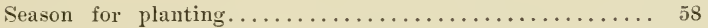

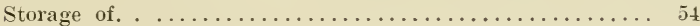

Selection form of sylviculture................. 156

Selection types (methods) of natural seed regeneration.120,134, 140

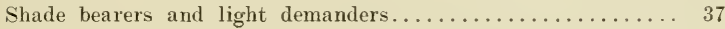

Shade bearing leaves............................... 13

Shelterwood types (methods) of natural seed regeneration.... 122

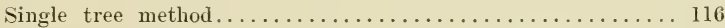

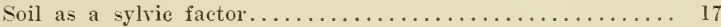

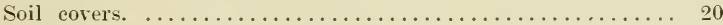

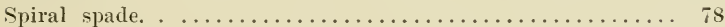

Sprout forests. . ..................

Sprout forests defined....................... 30

Sprout forest:

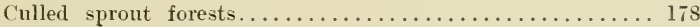

Cultured sprout forests.................... 179

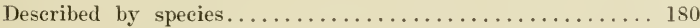

Forms of sprout forests...................... 177

Genesis of sprout forests.................... 174

Pedagogie of sprout forests....................

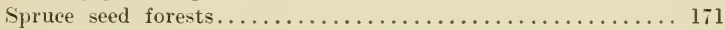

Spruce seedlings. . ....................98, 104

Spruce seeds, planting of $\ldots \ldots \ldots \ldots \ldots \ldots \ldots \ldots \ldots \ldots \ldots 6$

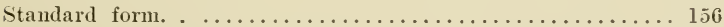

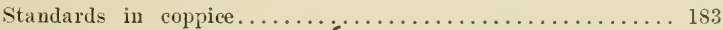

Strip types (methods) of natural seed regeneration...117, 130, 137

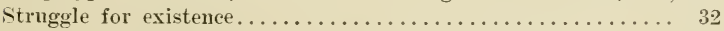

Stump sprouts. . ............................ 174

Systems of sylviculture, see forms 
Tamarack seedlings. . . . . . . . . . . . . . . . . . 99

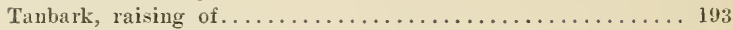

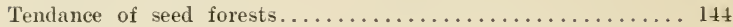

Tendance of sprout forests................... 176

Thinnings :

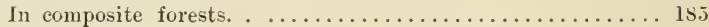

In seed forests. . ............................. 147

In sprout forests. . ...................... 17

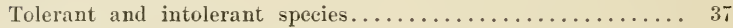

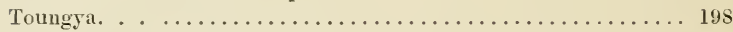

Transplanting in the nursery............................ 91

Treatment of the various forms of forests............ 157

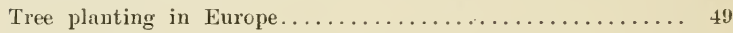

Two-storied seed forests......................... 157

Types of natural seed regeneration.................

U

Underplanting in seed forests..................

Underwood in the composite forest................ 184

IV

Walnut seed forests..........................

Walnut seedlings. . ..................... 100

Walnuts, planting of $\ldots \ldots \ldots \ldots \ldots \ldots \ldots \ldots \ldots \ldots \ldots \ldots \ldots$

Wieeding:

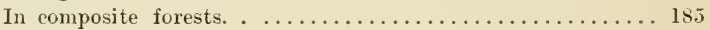

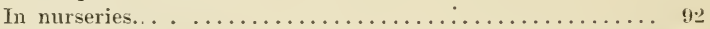

In seed forests. . . . . . . . . . . . . . . . . .

In sprout forests. . . . . . . . . . . . . . . . . . . . . 176

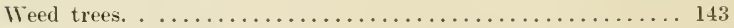

White Pine seed forests....................... 172

White Pine seedlings........................... 9s

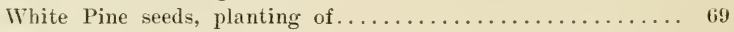

Wind as a sylvic factor........................... 16

$\mathbf{Y}$

Tellow Pine seed forests.................... 173

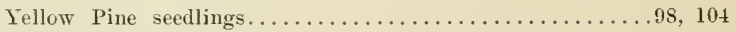

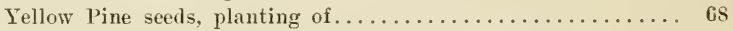

Yellow Poplar seed forests..................... 169

Fellow Poplar seedlings...................... 96

Yellow Poplar seeds, planting of ................ 66 



J67770? * n 4 4N

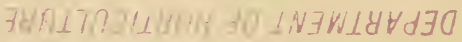



